COST EFFECTIVENESS OF THE STREAM-GAGING PROGRAM IN LOUISIANA

By Richard A. Herbert and Darrell D. Carlson

U.S. GEOLOGICAL SURVEY

Water-Resources Investigations Report 85-4044

Prepared in cooperation with the

U.S. ARMY CORPS OF ENGINEERS

New Orleans and Vicksburg Districts, LOUISIANA DEPARTMENT OF TRANSPORTATION AND DEVELOPMENT, and other State and Federal Agencies

Baton Rouge, Louisiana

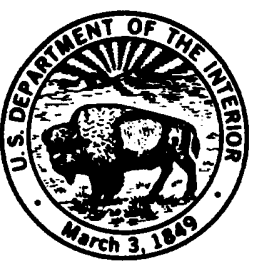




\author{
UNITED STATES DEPARTMENT OF THE INTERIOR \\ DONALD PAUL HODEL, Secretary \\ GEOLOGICAL SURVEY \\ Dallas L. Peck, Director
}

For additional information write to:

District Chief

U.S. Geological Survey

P.0. Box 66492

Baton Rouge, LA 70896

Telephone: (504) 389-0281
Copies of this report may be purchased from:

Open-File Services Section Western Distribution Branch U.S. Geological Survey Box 25425, Federal Center Denver, CO 80225

Telephone: (303) 236-7476 
Abstract-

Page

Introduction-_-__-

Acknowledgments-_._-_._-

History of the stream-gaging program in Louisiana-___._-

Current Louisiana stream-gaging program-_-

Uses, funding, and availability of continuous-streamflow data-_-_._-_-

Data-use classes

Regional hydrology-_-_

Hydrologic systems-_-_

Legal obligations-_-_

Planning and design-_____- 12

Project operation-_- 12

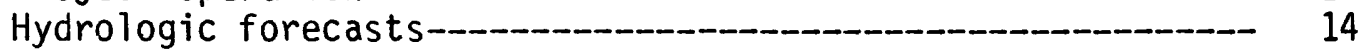

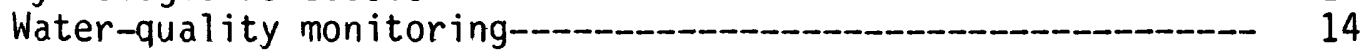

Research-_-_ 14

Funding-_-_ 15

Frequency of data availability and data use-_-_-_-_-_-_-_ 15

Conclusions pertaining to data uses-_- 16

Alternate methods of developing streamflow information-___________-_ 16

Description of flow-routing model-_._- 17

Description of regression analysis__. 19

Categorization of stream gages by their potential for

alternate methods-_- 20

Calcasieu River flow-routing analysis___________ 20

Regression analysis results-_- 24

Conclusions pertaining to alternative methods of data generation-_-_- 25

Cost-effective resource allocation-_-__- 26

Introduction to Kalman-filtering for cost-effective resource

allocation-_._- 26

Description of mathematical program-_an 26

Description of uncertainty functions-___-_ 29

The application of Kalman-filtering for cost-effective resource

allocation in Louisiana-_. 33

Determination of missing record probabilities-_-___-_ 34

Determination of coefficient of variation and crosscorrelation coefficient-_ 35

Kalman-filtering determination of variance-_______ $\quad 35$

Determination of routes-_. 42

Kalman-filtering for cost-effective resource allocation results-- 44

Summary-

Conclusions from the Kalman-filtering for cost-effective

resource allocation analysis-_ 56

Selected references-_- 58 


\section{ILLUSTRATIONS}

Figure 1. Graph showing number of continuous-streamflow gages in Louisiana, by year-_.

2-5. Maps showing:

2. Distribution of electromagnetic flowmeter stream gages and physiographic regions in Louisiana--_-_-- 6

3. Locations of continuous-streamflow stations in Louisiana

4. Locations of continuous-streamflow stations that supply data for regional hydrology-

5. Continuous-streamflow stations in the Calcasieu River
study area-

6A-D. Graphs showing daily hydrographs, Calcasieu River near Oberlin, Louisiana for:
A. August $1981-$
B. February 1982
C. April 1982

D. July 1982

7. Diagram showing mathematical-programming form of the optimization of the routing of hydrographers

8. Diagram showing tabular form of the optimization of the routing of hydrographers

9-11. Graphs showing:

9. Residual versus natural log of gage height for station 07348700, Bayou Dorcheat near Springhi11, Louisiana-----

10. Typical uncertainty functions for instantaneous discharges at two Louisiana stations

11. Average error or estimate versus operational budget for Louisiana

TABLES

Table 1. Selected hydrologic data for stations in the Louisiana surface-water program-_.-.

2. Use of Louisiana streamflow data-

3. Gaging stations used in the Calcasieu River flow-routing study, Louisiana----

4. Selected reach characteristics used in the Calcasieu River flow-routing study, Louisiana--

5. Results of routing model for Oberlin station, Louisiana---

6. Summary of calibration for regression modeling of mean daily streamflow at Calcasieu River near Oberlin, Louisiana (08013500)

7. Results of missing record analysis for stream-gaging stations in Louisiana, water years 1975-82--

8. Statistics used in reconstructing records for Louisiana stream gages-_-

9. Stations for which only the upper part of the stagedischarge relationship was used for the determination of variance-

10. Residual data for Bayou Pierre near Lake End, Louisiana---

11. Residual data for Dugdemona River near Jonesboro, Louisiana 
12. Summary of the autocovariance analysis of the Louisiana

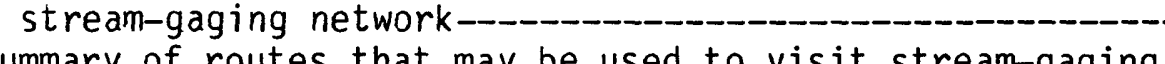

13. Summary of routes that may be used to visit stream-gaging stations in Louisiana-_-_-_-_-_-_-_-_-_-_-_-_-_-_-_

14. Selected results of Kalman-filtering for cost-effective resource allocation analysis of Louisiana stream-gaging network

15. Stations suggested for altered visitation schedules as a result of the Kalman-filtering for cost-effective resource allocation analysis

FACTORS FOR CONVERTING INCH-POUND UNITS TO INTERNATIONAL SYSTEM (SI) OF METRIC UNITS

Multiply

foot $(f t)$

mile (mi)

square mile $\left(m i^{2}\right)$

cubic foot $\left(\mathrm{ft}^{3}\right)$

cubic foot per second $(\mathrm{ft} 3 / \mathrm{s})$
By

0.3048

1.609

2.590

0.02832

0.02832
To obtain

meter (m)

kilometer $(\mathrm{km})$

square kilometer $\left(\mathrm{km}^{2}\right)$

cubic meter $\left(\mathrm{m}^{3}\right)$

cubic meter per second $\left(\mathrm{m}^{3} / \mathrm{s}\right)$ 


\title{
COST EFFECTIVENESS OF THE STREAM-GAGING PROGRAM IN LOUISIANA
}

\author{
By Richard A. Herbert and Darrell D. Carlson
}

\section{ABSTRACT}

This report documents the results of a study of the cost effectiveness of the stream-gaging program in Louisiana. Data uses and funding sources were identified for the 68 continuous-record stream gages currently (1984) in operation with a budget of $\$ 408,700$. Two stream gages were identified as having uses specific to a short-term study with no need for continued data collection beyond the study. The remaining 65 stations should be maintained in the program for the future. In addition to the current operation of continuous-record stations, a number of wells, floodprofile gages, crest-stage gages, and stage stations are serviced on the continuous-record station routes, thus, increasing the budget to $\$ 423,000$.

The average standard error of estimate for streamflow values at the 68 stations is 34.6 percent. Standard errors computed in this study are one measure of streamflow errors, and the standard errors can be used as guides in comparing the effectiveness of alternative networks. The results also show that by using the routes and number of measurements prescribed by the "Traveling Hydrographer Program," the standard error could be reduced to 31.5 percent with the current budget of $\$ 423,000$. If the gaging resources are redistributed, the 34.6 percent overall level of accuracy at the continuous-record sites and the servicing of the additional wells and gages could be maintained with a budget of approximately $\$ 410,000$.

A minimum budget of $\$ 400,000$ is required to operate the current program; a budget less than this would not permit proper service and maintenance of the gages and recorders. At the minimum budget, the average standard error is 39.6 percent. The maximum budget analyzed was $\$ 600,000$, which resulted in an average standard error of 16.3 percent.

The study indicates that a major source of error is due to lost or missing data. If perfect equipment were available, the standard error for the current program and budget could be reduced to 11.8 percent. This can also be interpreted to mean that the streamflow data have a standard error of this magnitude during times when equipment is operating properly.

The study also shows that additional data collection is needed in urban areas and in the coastal marsh region. In 1983, the U.S. Geological Survey increased data collection in both of these areas, but there were not enough discharge measurements to be included in this study. 
The U.S. Geological Survey is the principal Federal agency collecting surface-water data in the Nation. The collection of these data is a major activity of the Water Resources Division of the U.S. Geological Survey. The data are collected in cooperation with State and local governments and other Federal agencies. In 1983, the Survey was operating approximately 8,000 continuous-record gaging stations throughout the Nation. Some of these records extend back to the turn of the century. Any activity of long standing, such as the collection of surface-water data, should be re-examined at intervals, if not continuously, because of changes in objectives, technology, or external constraints. The last systematic nationwide evaluation of the streamflow information program was completed in 1970 and was documented by Benson and Carter (1973). The Survey is presently (1983) undertaking another nationwide analysis of the streamgaging program that will be completed over a 5-year period with 20 percent of the programs being analyzed each year. The objective of this analysis is to define and document the most cost-effective means of furnishing streamflow information.

For every continuous-record gaging station, the analysis identifies the principal uses of the data and relates these uses to funding sources. Gaged sites for which data are no longer needed are identified as are deficient or unmet data needs. In addition, gaging stations are categorized as to whether the data are available to users in a real-time sense, on a provisional basis, or at the end of the water year.

The second aspect of the analysis is to identify less costly methods of furnishing the needed information; among these are flow-routing models and statistical methods. The stream-gaging activity no longer is considered a network of observation points, but rather an integrated information system in which data are provided both by observation and synthesis.

The final part of the analysis involves the use of Kalman-filtering and mathematical-programing techniques to define strategies for operation of the necessary stations that minimize the uncertainty in the streamflow records for given operating budgets. Kalman-filtering technique is used to compute uncertainty functions (relating the standard errors of computation or estimation of streamflow records to the frequency of visits to the stream gages) for all stations in the analysis. A steepest descent optimization program uses these uncertainty functions, information on practical stream-gaging routes, the various costs associated with stream gaging, and the total operating budget to identify the visit frequency for each station that minimizes the overall uncertainty in the streamflow. The stream-gaging program that results from this analysis will meet the expressed water-data needs in the most cost-effective manner.

This report consists of five sections; the first is an introduction to the stream-gaging activities in Louisiana and to the study itself. The middle three sections each contain discussions of individual steps of the analysis. Because of the sequential nature of the steps and the dependence of subsequent steps on the previous results, summaries of 
conclusions are made at the end of each of the middle three sections. The complete study is summarized in the final section.

The standard errors of estimate given in this report are those that would occur if daily discharges were computed through the use of methods described in this study. No attempt has been made to estimate standard errors for discharges that are computed by other means. Such errors could differ greatly from the errors computed in this report. The magnitude and direction of the differences would be a function of methods used to account for shifting controls and for estimating discharges during periods of missing record.

\section{Acknowledgments}

This report is one of a series of reports being prepared for each District of the Survey, Water Resources Division. A large part of this report is taken directly from reports by Fontaine and others (1983) and by Hale and others (1984) for analyses conducted in Maine and Georgia, respectively. The analysis for Louisiana was completed with assistance from Wilbert 0. Thomas, Jr. and Vernon B. Sauer of the U.S. Geological Survey.

\section{History of the Stream-Gaging Program in Louisiana}

The program of surface-water investigations by the Survey in Louisiana grew steadily from 1930 through 1955, then remained fairly constant until 1965. Stream-gaging efforts decreased steadily from 1965 until 1970 and have remained fairly constant for the past 14 years. The first Survey surface-water gaging station in Louisiana was installed on the Sabine River at Logansport in July 1903. This state-boundary station can be claimed by both Texas and Louisiana and was operated by the Texas District. The first streamflow records to be published were for Bayou Cocodrie near Clearwater, La., for the years 1922 to 1925. Two Calcasieu River stations (near Oberlin and near Kinder, La.) were added to the network. These stations were operated by the Texas District and the Louisiana Gravity Canal Company. The Survey entered into its first cooperative agreement in Louisiana with Louisiana State University and Agricultural and Mechanical College in 1933 and jointly published the streamflow data for Bayou Duplantier at City Lake in Baton Rouge, La. The Louisiana District was established in 1938 when the Survey entered into a cooperative agreement with the Louisiana Department of Conservation and also received financial support from the U.S. Army Corps of Engineers. At that time, an expanded program of systematic collection of streamflow data in Louisiana was begun. The Louisiana Department of Highways supported the cooperative program for 1 year in 1942. During that year, the Louisiana Department of Public Works also entered into a cooperative agreement and has continued as a cooperator ever since. The Louisiana Department of Highways entered into a cooperative agreement again in 1948 and has continued to support the surface-water program from that time to the present. Both of the above State agencies are now within the Department of Transportation and Development. The number of continuous streamflow stations operated annually within the State of Louisiana, since the program began, are shown in figure 1. 


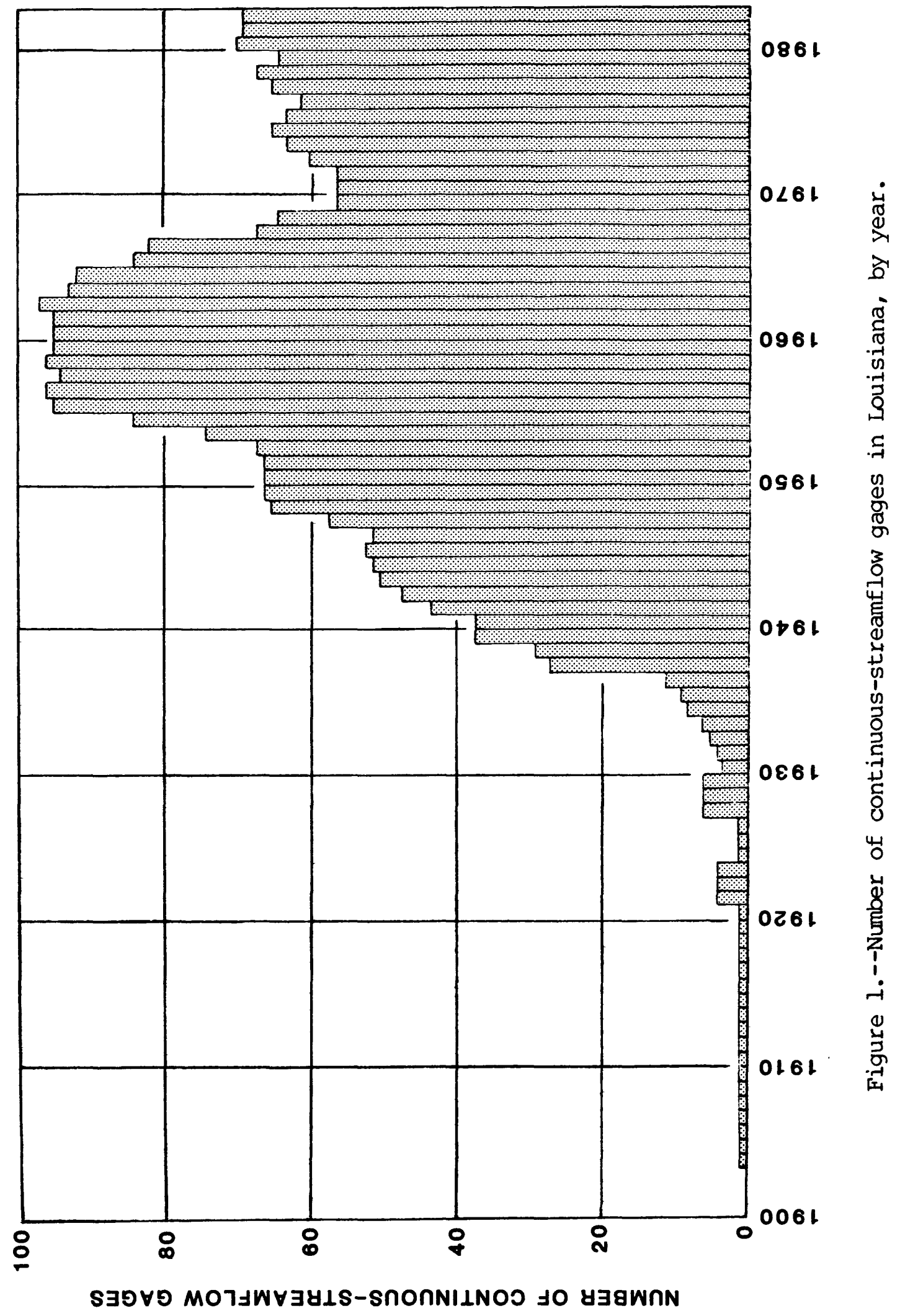




\section{Current Louisiana Stream-Gaging Program}

Louisiana can be divided into four major physiographic regions as noted by Sauer (1964)--the coastal marshes, the prairies, the pine hills, and the alluvial plains (fig. 2). The distribution of the 68 continuousstreamflow stations currently operated (1984) by the Louisiana District of the U.S. Geological Survey are shown in figure 3. Forty-five gages are located in the pine hills region, seven in the prairies, 15 in the alluvial plains, and one in the coastal marsh. Until recently, the coastal marsh region was devoid of continuous-streamflow stations.

In 1983 and 1984, 10 electromagnetic flowmeters were installed, six in the lower prairie region, three in the alluvial plains, and one in the coastal marsh region (fig. 2). Three urban stations were established in the Baton Rouge metropolitan area in 1983. None of these stations were included in this network analysis.

The cost of operating the 68 continuous-record stream gages in fiscal-year 1984 was $\$ 408,700$. In addition, a number of wells, creststage gages, flood-profiles, and stage stations are serviced on the same routes as the stream gages. The cost of operating the 68 continuousrecord stream gages and field servicing of the non-continuous-record gages is about $\$ 423,000$ (1984).

Selected hydrologic data for the 68 stations, including drainage area, period of record, and mean annual flow, are given in table 1. Station identification numbers used throughout this report are the U.S. Geological Survey's eight-digit downstream-order station number. The first two digits of this station number represent the basin part number and the last six represent the station number. In figures 3 and 4 , the part number has been left off because the area for each part has been delineated on the maps. Part 02 represents the eastern Gulf of Mexico basin, part 07 represents the lower Mississippi River basin, and part 08 represents the western Gulf of Mexico basin.

\section{USES, FUNDING, AND AVAILABILITY OF CONTINUOUS-STREAMFLOW DATA}

The relevance of a stream gage is defined by the uses that are made of data produced from the gage. The uses of the data from each gage in the Louisiana program were identified by a survey of known data users. The survey documented the importance of each gage and identified gaging stations that may be considered for discontinuation.

Data uses identified in the survey were categorized into eight classes (table 2), defined below. The sources of funding for each gage and the frequency at which data are provided to the users were also compiled.

\section{Data-Use Classes}

The following definitions were used to categorize each known use of streamflow data for each continuous stream gage. 


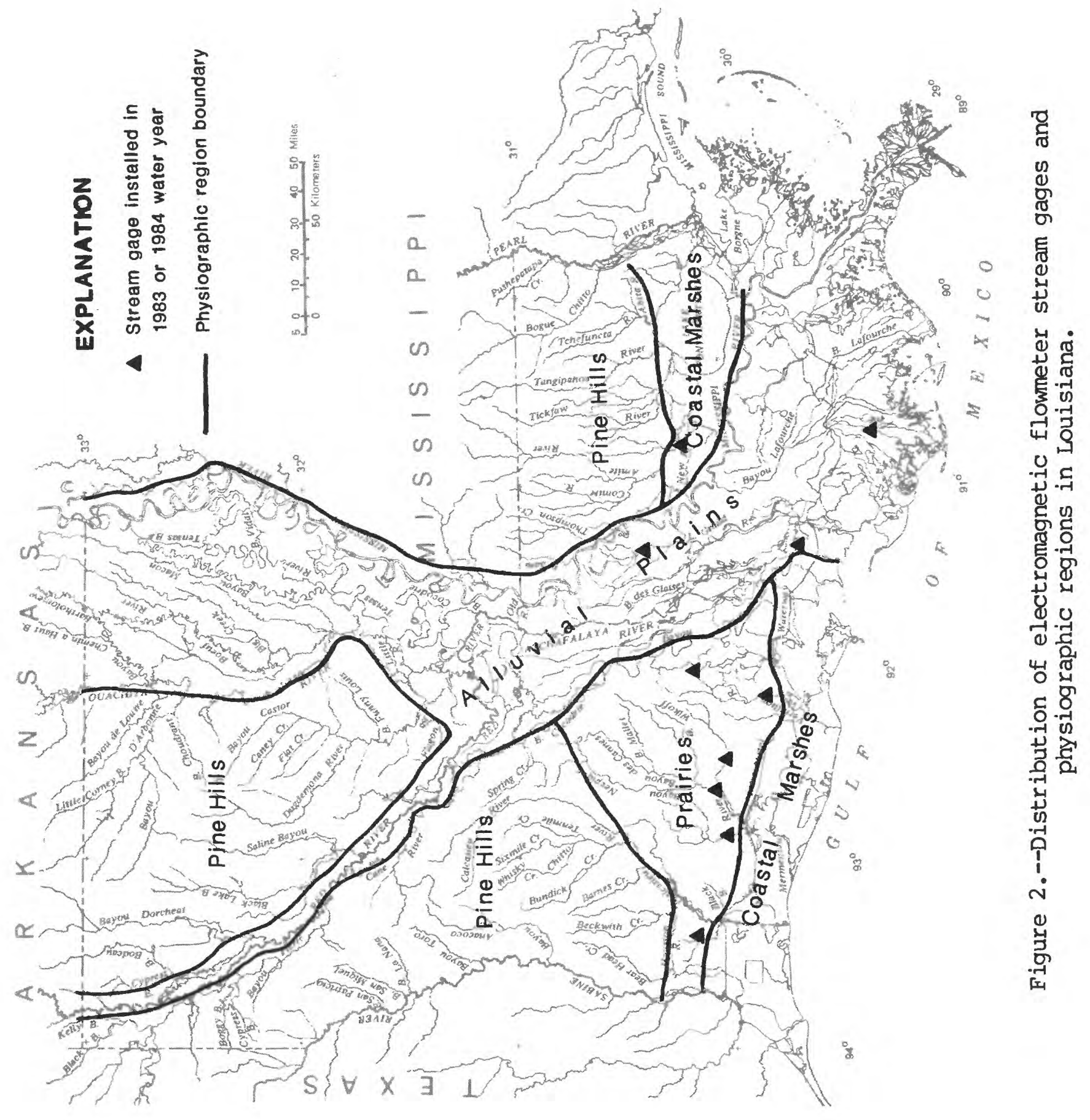



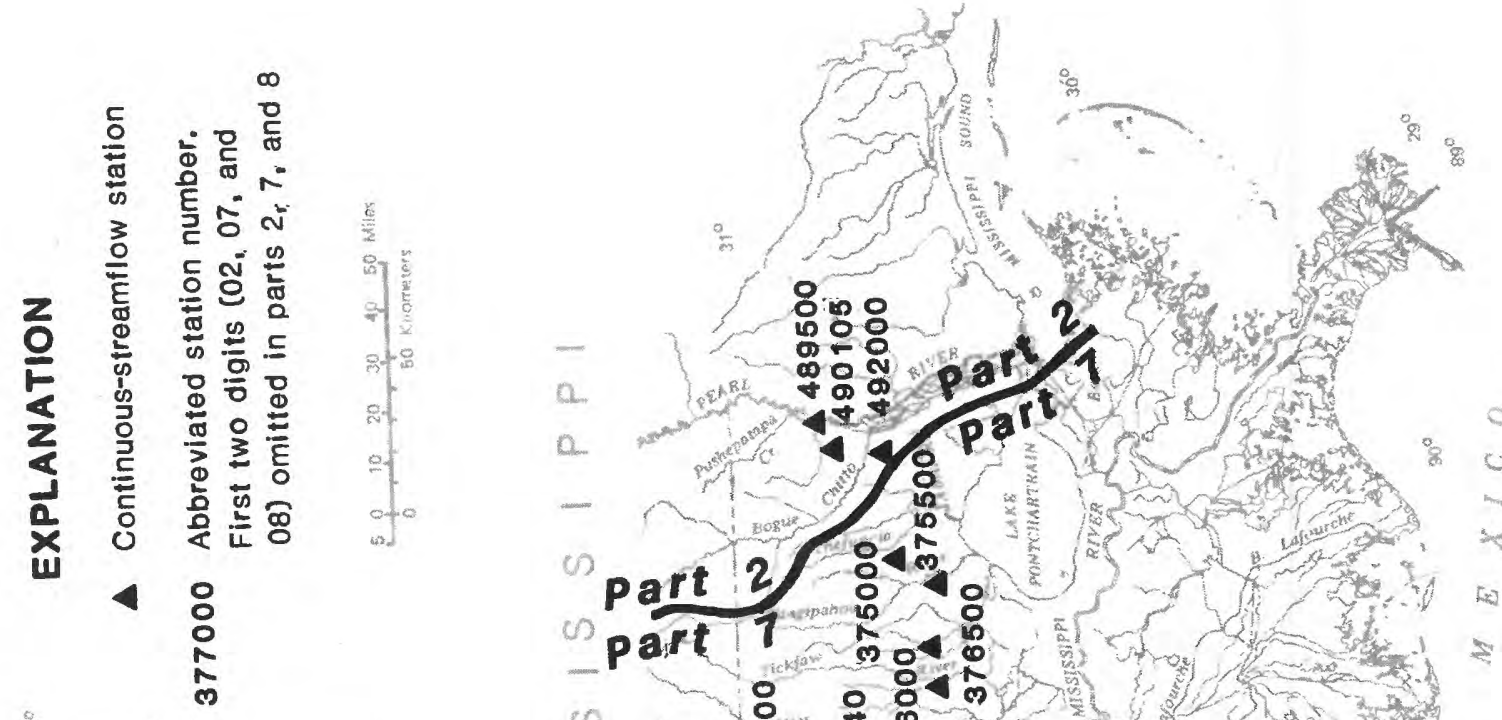

告
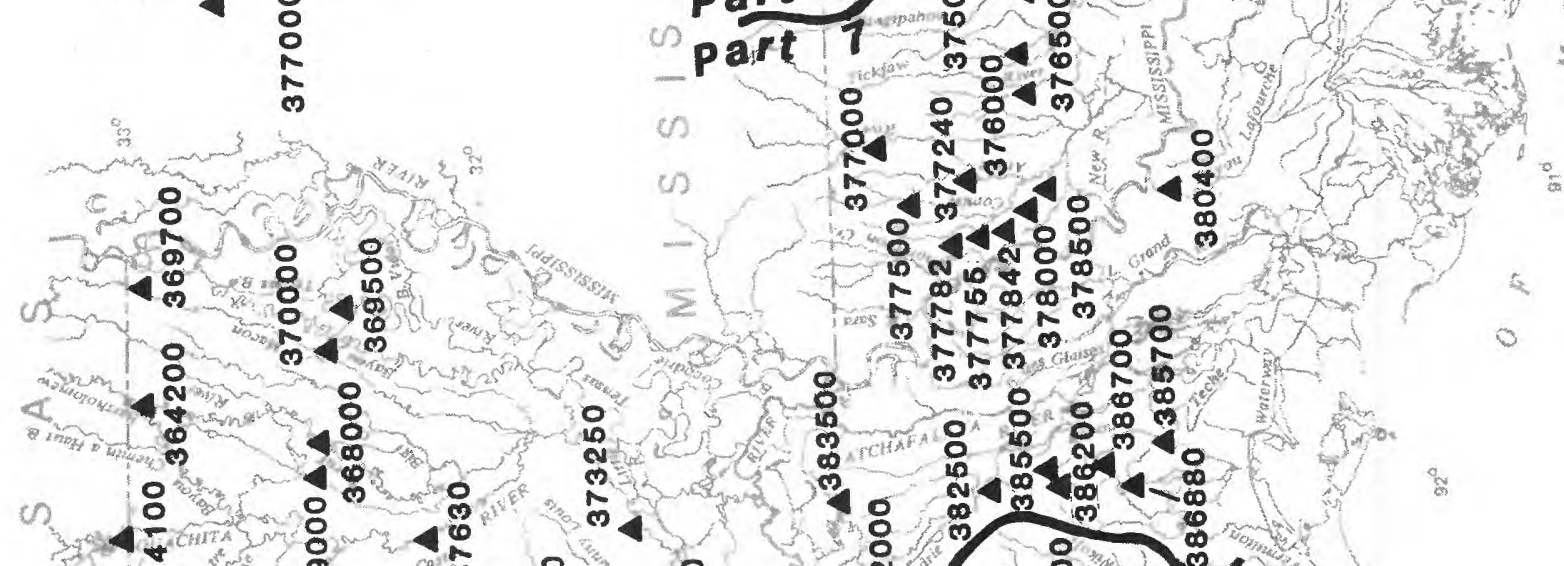

- 1

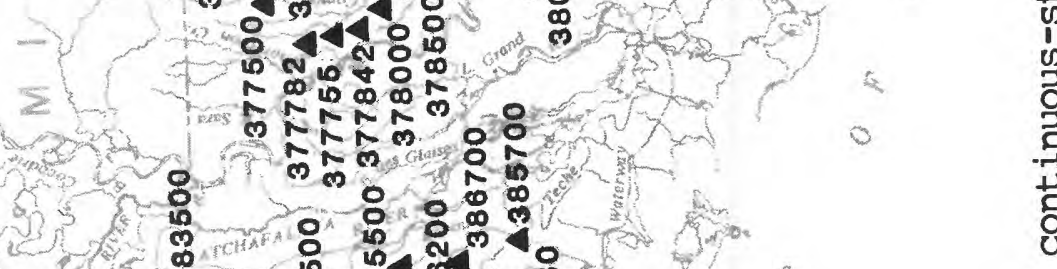

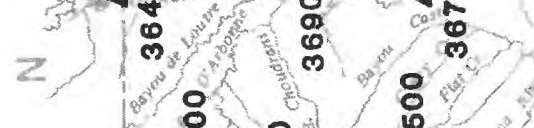
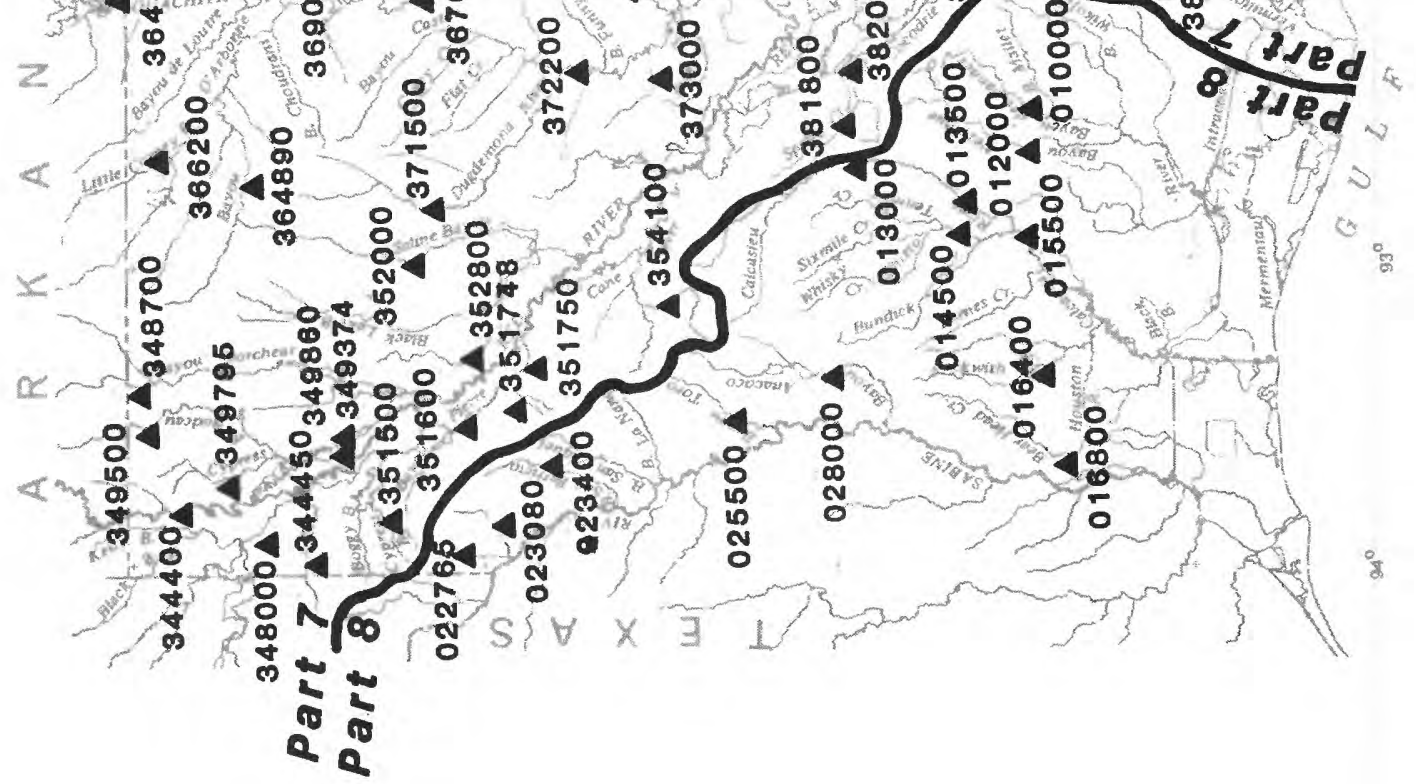
Table 1.--Selected hydrologic data for stations in the Louisiana surface-water program

\begin{tabular}{|c|c|c|c|c|c|}
\hline $\begin{array}{l}\text { Map } \\
\text { index } \\
\text { number }\end{array}$ & $\begin{array}{l}\text { Station } \\
\text { number }\end{array}$ & Station name & $\begin{array}{c}\text { Drainage } \\
\text { area } \\
\text { (square miles) }\end{array}$ & $\begin{array}{l}\text { Period of } \\
\text { record } \\
\text { (water years) }\end{array}$ & $\begin{array}{l}\text { Mean-annual } \\
\text { flowa } \\
\text { (cubic foot } \\
\text { per second) }\end{array}$ \\
\hline 1 & 02489500 & Pearl River near Bogalusa--_-_-_- & 6,573 & 1939 & 9,599 \\
\hline 2 & 02490105 & $\begin{array}{l}\text { Bogue Lusa Creek at State Highway } 439 \text {, } \\
\text { at Bogalusa. }\end{array}$ & 72.7 & $1964-$ & 116 \\
\hline 3 & 02492000 & Bogue Chitto near Bush-_-_-_-_- & 1,213 & 1938- & 1,916 \\
\hline 4 & 07344400 & Red River near Hosston-_- & $\mathrm{b} / 57,041$ & $1958-68, \mathrm{C} / 1969$ & d/ 17,920 \\
\hline 5 & 07344450 & Paw Paw Bayou near Greenwood-_- & 80.5 & 1955- & 63.4 \\
\hline 6 & 07348000 & Twelvemile Bayou near Dixie-_-_-__-_-_ & 3,137 & $1942-$ & 2,545 \\
\hline 7 & 07348700 & Bayou Dorcheat near Springhill-_-_-_-- & 605 & 1957- & 541 \\
\hline 8 & 07349374 & Flat River near Curt is- & (e) & $1980-$ & \\
\hline 9 & 07349500 & $\begin{array}{l}\text { Bodcau Bayou (Bayou Bodcau) near } \\
\text { Sarepta. }\end{array}$ & 546 & 1938- & 562 \\
\hline 10 & 07349795 & Cypress Bayou above Benton-_-_-_-_-_-_-- & 88.9 & $1974-$ & 72.2 \\
\hline 11 & 07349860 & Red Chute Bayou at Sligo & 980 & 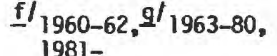 & $\ldots$ \\
\hline 12 & 07350020 & Loggy Bayou near East Point-_- & 2,648 & 1980 & \\
\hline 13 & 07351500 & Cypress Bayou near Keithville--_-_-_-_-_ & $\underline{n} / 166$ & $\begin{array}{l}1939-57,-1958-82 \text {, } \\
1983-\end{array}$ & i/ 74.8 \\
\hline $\begin{array}{l}14 \\
15\end{array}$ & $\begin{array}{l}07351600 \\
07351748\end{array}$ & $\begin{array}{l}\text { Bayou Pierre near Grand Bayou-- } \\
\text { West Branch Dolet Bayou at Rambin-- }\end{array}$ & $\begin{array}{l}661 \\
32.3\end{array}$ & $\begin{array}{l}j / 1978-79,1980- \\
1980-\end{array}$ & - \\
\hline $\begin{array}{l}16 \\
17\end{array}$ & $\begin{array}{l}07351750 \\
07352000\end{array}$ & $\begin{array}{l}\text { Bayou Pierre near Lake End-_- } \\
\text { Saline Bayou near Lucky- }\end{array}$ & $\begin{array}{l}860 \\
154\end{array}$ & $\begin{array}{l}\text { g/ } 1960-80,1981- \\
1941-\end{array}$ & ---160 \\
\hline 18 & 07352800 & Grand Bayou near Coushatta-_-_- & 93.9 & $1957-77,1980-$ & $\underline{k} / 85.7$ \\
\hline 19 & 07354100 & Kisatchie Bayou at Lotus- & 140 & m/ $1956-63,1980$ & ------ \\
\hline 20 & 07364100 & $\begin{array}{l}\text { Ouachita River near Arkansas-Louisiana } \\
\text { state line. }\end{array}$ & 10,787 & n/ 1959 & --.-- \\
\hline $\begin{array}{l}21 \\
22\end{array}$ & $\begin{array}{l}07364200 \\
07364890\end{array}$ & $\begin{array}{l}\text { Bayou Bartholomew near Jones-- } \\
\text { Bayou D'Arbonne near Hico- }\end{array}$ & 1,187 & $1958-$ & 1,239 \\
\hline 23 & 07366200 & $\begin{array}{l}\text { Bayou D'Arbonne near Hico- } \\
\text { Little Corney Bayou near Lillie- }\end{array}$ & $\begin{array}{l}254 \\
208\end{array}$ & $\begin{array}{l}1981- \\
1956-\end{array}$ & 184 \\
\hline 24 & 07367630 & $\begin{array}{l}\text { Ouachita River at Columbia Lock and Dam, } \\
\text { near Riverton. }\end{array}$ & 15,630 & $1976-$ & 15,030 \\
\hline 25 & $0736 \mathrm{~B} 000$ & Boeuf River near Girard-__ & of 1,226 & $1939-$ & 356 \\
\hline 26 & 07369000 & Bayou Lafourche near Crew Lake-_-_-_-_- & 의 361 & p/1939- & 1,647 \\
\hline 27 & 07369500 & Tensas River at Tendal-_- & 의 309 & p/1936- & 328 \\
\hline 28 & 07369700 & Bayou Macon near Kilbourne--_-_-_- & 의 504 & $1958-68,9 / 1968-$ & $\underline{d} / 508$ \\
\hline 29 & 07370000 & Bayou Macon near Delhi-_- & 782 & $p^{\prime} 1936-$ & 972 \\
\hline 30 & 07371500 & Dugdemona River near Jonesboro---- & 355 & $\begin{array}{l}1939-57,-\underline{r} / 1958-77, \\
1978-\end{array}$ & $\underline{s} / 399$ \\
\hline 31 & 07372200 & Little River near Rochelle-_-_-__-_-_-_ & 1,899 & $1958-$ & 1,961 \\
\hline 32 & 07373000 & Big Creek at Pollock-_- & $\underline{h} / 51$ & $1943-$ & 59.5 \\
\hline 33 & 07373250 & Hempnill Creek at Nebo-- & 35.3 & $\mathrm{~m} / 1956-70,1979$ & $-\cdots$ \\
\hline $\begin{array}{l}34 \\
35 \\
36 \\
37\end{array}$ & $\begin{array}{l}07375000 \\
07375500 \\
07376000 \\
07376500\end{array}$ & $\begin{array}{l}\text { Tchefuncta River near Folsom- } \\
\text { Tangipahoa River at Robert-- } \\
\text { Tickfaw River at Holden-- } \\
\text { Natalbany River at Baptist-- }\end{array}$ & $\begin{array}{l}\mathrm{t} / 95.5 \\
646 \\
247 \\
79.5\end{array}$ & $\begin{array}{l}\text { u/ } 1944- \\
1939- \\
1941- \\
1944-\end{array}$ & $\begin{array}{r}159 \\
1,129 \\
366 \\
114\end{array}$ \\
\hline $\begin{array}{l}38 \\
39\end{array}$ & $\begin{array}{l}07377000 \\
07377240\end{array}$ & $\begin{array}{l}\text { Amite River near Darlington-_-_._- } \\
\text { Little Sandy Creek near Greenwell }\end{array}$ & 580 & $\underline{f} / 1949-50,1951-$ & 893 \\
\hline $\begin{array}{l}40 \\
41\end{array}$ & $\begin{array}{l}07377500 \\
07377755\end{array}$ & $\begin{array}{l}\text { Springs. } \\
\text { Comite River near Olive Branch--.---- } \\
\text { White Bayou East Diversion Channel near } \\
\text { Baton Rouge. }\end{array}$ & $\begin{array}{l}28.2 \\
145 \\
(e)\end{array}$ & $\begin{array}{l}1975- \\
1943- \\
1973-\end{array}$ & $\begin{array}{l}52.5 \\
228 \\
9.83\end{array}$ \\
\hline $\begin{array}{l}42 \\
43\end{array}$ & $\begin{array}{l}07377782 \\
07377842\end{array}$ & $\begin{array}{l}\text { White Bayou southeast of Zachary- } \\
\text { White Bayou near Baker- }\end{array}$ & $\begin{array}{r}{ }^{h} / 45 \\
(e)\end{array}$ & $\begin{array}{l}1973- \\
1973-\end{array}$ & $\begin{array}{l}76.5 \\
11.7\end{array}$ \\
\hline $\begin{array}{l}44 \\
45 \\
46\end{array}$ & $\begin{array}{l}07378000 \\
07378500 \\
07380400\end{array}$ & $\begin{array}{l}\text { Comite River near Comite- } \\
\text { Amite River near Denham Springs- } \\
\text { Bayou Lafourche at Donaldsonville- }\end{array}$ & $\begin{array}{l}\frac{v}{\prime} 284 \\
1,280 \\
(w)\end{array}$ & $\begin{array}{l}1945- \\
1939- \\
1958-\end{array}$ & $\begin{array}{r}457 \\
1,966 \\
244\end{array}$ \\
\hline $\begin{array}{l}47 \\
48\end{array}$ & $\begin{array}{l}07381800 \\
07382000\end{array}$ & $\begin{array}{l}\text { Spring Creek near Glenmora-- } \\
\text { Bayou Cocodrie near Clearwater-- }\end{array}$ & $\begin{array}{l}68.4 \\
240\end{array}$ & $\begin{aligned} f / 1954-56, & 1957- \\
1923-24, & 1938-\end{aligned}$ & 410.8 \\
\hline 49 & 07382500 & Bayou Courtableau at Washington-_-_-_-_ & of 715 & $1947-$ & 1,044 \\
\hline
\end{tabular}


Table 1.--Selected hydrologic data for stations in the Louisiana surface-water program--Continued

\begin{tabular}{|c|c|c|c|c|c|}
\hline $\begin{array}{l}\text { Map } \\
\text { index } \\
\text { number }\end{array}$ & $\begin{array}{l}\text { Station } \\
\text { number }\end{array}$ & Station name & $\begin{array}{c}\text { Drainage } \\
\text { area } \\
\text { (square miles) }\end{array}$ & $\begin{array}{l}\text { Period of } \\
\text { record } \\
\text { (water years) }\end{array}$ & $\begin{array}{l}\text { Mean-annual } \\
\quad \text { flow } \\
\text { (cubic foot } \\
\text { per second) }\end{array}$ \\
\hline 50 & 07383500 & $\begin{array}{l}\text { Bayou Des Glaises Diversion Channel } \\
\text { at Moreauville. }\end{array}$ & $\underline{x} I_{270}$ & 1944- & 422 \\
\hline $\begin{array}{l}51 \\
52\end{array}$ & $\begin{array}{l}07385500 \\
07385700\end{array}$ & $\begin{array}{l}\text { Bayou Teche at Arnaudville-- } \\
\text { Bayou Teche at Keystone Lock, near } \\
\text { St. Martinville. }\end{array}$ & $\begin{array}{l}(e) \\
(e)\end{array}$ & $\begin{array}{l}1950- \\
1960-\end{array}$ & $\begin{array}{l}816 \\
501\end{array}$ \\
\hline $\begin{array}{l}53 \\
54 \\
55\end{array}$ & $\begin{array}{l}07386200 \\
07386700 \\
07386880\end{array}$ & $\begin{array}{l}\text { Bayou Fusilier at Weir, near Arnaudville- } \\
\text { Ruth Canal near Ruth-- } \\
\text { Vermilion River at Surrey St. at } \\
\text { Lafayette. }\end{array}$ & $\begin{array}{l}(e) \\
(w) \\
(e)\end{array}$ & $\begin{array}{l}y / 1981-82, \quad 1983- \\
\quad 1960- \\
\quad 1968-\end{array}$ & ב-ב- \\
\hline 56 & 08010000 & Bayou Des Cannes near Eunice-_. & 131 & 1939- & 265 \\
\hline 57 & 08012000 & Bayou Nezpique near Basile-_-_-_ & 527 & 1939 & 808 \\
\hline 58 & 08013000 & Calcasieu River near Glenmora-_. & 499 & $1944-$ & 700 \\
\hline 59 & 08013500 & Calcasieu River near Oberlin- & 753 & $1923-24,1939$ & 1,120 \\
\hline 60 & 08014500 & Whisky Chitto Creek near Oberlin-__- & 510 & $1940-$ & 792 \\
\hline 61 & 08015500 & Calcasieu River near Kinder-_-_-_ & 1,700 & $1923-24,1939-57$, & 2,510 \\
\hline 62 & 08016400 & Beckwith Creek near DeQuincy & 148 & $1946-$ & 194 \\
\hline $\begin{array}{l}63 \\
64 \\
65\end{array}$ & $\begin{array}{l}08016800 \\
08022765 \\
08023080\end{array}$ & $\begin{array}{l}\text { Bear Head Creek near Starks- } \\
\text { Bayou Castor near Funston- } \\
\text { Bayou Grand Cane near Stanley- }\end{array}$ & $\begin{array}{r}177 \\
91.5 \\
72.5\end{array}$ & $\begin{array}{l}\underline{z} / 1954-56,1957- \\
\quad 1972- \\
\quad 1981-\end{array}$ & $\begin{array}{r}229 \\
61.9 \\
\end{array}$ \\
\hline 66 & 08023400 & Bayou San Patricio near Benson-___-__-_ & 80.2 & z/ $1954-68,1978$ & 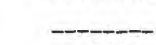 \\
\hline 67 & 08025500 & Bayou Toro near Toro-- & 148 & 1956 & 138 \\
\hline 68 & 08028000 & Bayou Anacoco near Rosepine-_ & 365 & $1952-$ & 423 \\
\hline
\end{tabular}

a Mean-annual flow values are computed through 1982 water year.

5, 936 square miles above Denison Dam is

noncontributing.
Once-daily gage heights by observer and discharges below 5,000 cubic feet per second.

d For period 1958-68.

e Indeterininate.

f Operated as crest-stage gage.

9 Operated as flood-profile gage.

Approximately.

Daily gage heights, annual maximums, and daily discharge below 400 cubic feet per

k For period $1957-77,1980-82$

moccasional low-flow and/or fiscellaneous

measurements oniy.

$n$ Daily gage heights and daily discharges below 19.0 feet only.

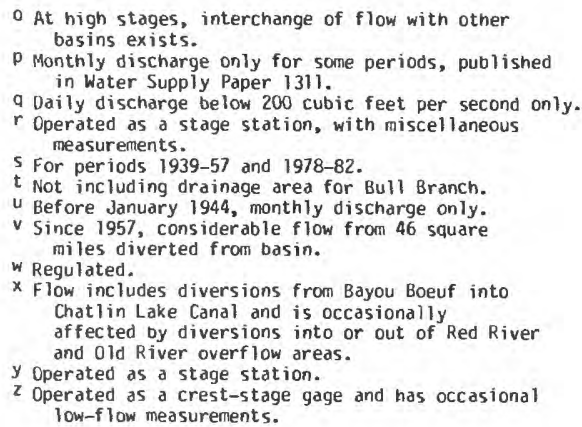

0 At high stages, interchange of flow with other

onthly discharge only for some periods, published

in Water Supply Paper 1311 .

$r$ and second only.

perated as a stage station, with miscellaneous

For periods 1939-57 and 1978-82.

Not including drainage area for Bull Branch.

Before January 1944, manthly discharge only.

miles diverted from basin.

w Regulated.

$x$ Flow includes diversions from Bayou Boeuf into Chat lin Lake Canal and is occasionally affected by diversions into or out of Red River and Old River overflow areas.

y Operated as a stage station.

$z$ Operated as a crest-stage gage and has occasional low-flow measurements.

\section{Regional Hydrology}

For data to be useful in defining regional hydrology, a stream gage must be largely unaffected by manmade storage or diversion. In this class of uses, the effects of man on streamflow are not necessarily sma11, but the effects are limited to those caused primarily by land-use and climate changes. Large amounts of manmade storage may exist in the basin providing the outflow is uncontrolled. These stations are useful in developing regionally transferable information about the relationship between basin characteristics and streamflow.

Thirty-four stations in the Louisiana network are classified in the regional hydrology data-use category. Three of the stations are special because they are designated bench-mark or index stations. There is one hydrologic bench-mark station in Louisiana, Big Creek at Pollock, which serves as an indicator of hydrologic conditions in watersheds relatively 
Table 2.--Use of Louisiana streamflow data

[A, data available on annual basis; $P$, data available on a periodic basis;

$T$, data avavailable on a real-time basis]

\begin{tabular}{|c|c|c|c|c|c|c|c|c|c|c|c|c|c|}
\hline \multirow[b]{2}{*}{ Station no. } & \multicolumn{8}{|c|}{ Data Use } & \multicolumn{4}{|c|}{ Funding } & \multirow[b]{2}{*}{$\begin{array}{c}\text { Data } \\
\text { avail- } \\
\text { ability }\end{array}$} \\
\hline & 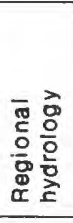 & 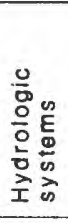 & 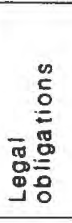 & 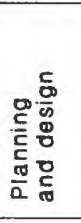 & 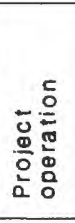 & 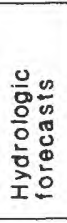 & 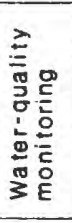 & $\begin{array}{l}\text { c } \\
0 \\
0 \\
0 \\
0 \\
0 \\
\Phi \\
\mathbb{1}\end{array}$ & 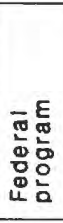 & 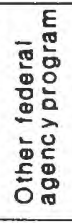 & 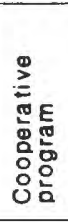 & 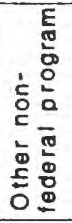 & \\
\hline $\begin{array}{l}02489500 \\
02490105 \\
02492000\end{array}$ & $\begin{array}{l}4 \\
4\end{array}$ & 1 & & & & 2 & $\begin{array}{l}3 \\
3\end{array}$ & & 4 & 6 & 5 & & $\begin{array}{l}A, P, T \\
A \\
A\end{array}$ \\
\hline $\begin{array}{l}07344400 \\
07344450 \\
07348000\end{array}$ & 4 & & & & $\begin{array}{l}7 \\
8 \\
9\end{array}$ & & $\begin{array}{l}4 \\
3\end{array}$ & & & & $\begin{array}{l}5 \\
5 \\
5\end{array}$ & & $\begin{array}{l}A \\
A \\
A\end{array}$ \\
\hline $\begin{array}{l}07348700 \\
07349374 \\
07349500\end{array}$ & $\begin{array}{l}4 \\
4\end{array}$ & & & 10 & $\begin{array}{l}10 \\
12\end{array}$ & & & 11 & & $\begin{array}{l}6 \\
6\end{array}$ & 5 & & $\begin{array}{l}A \\
A \\
A\end{array}$ \\
\hline $\begin{array}{l}07349795 \\
07349860 \\
07350020\end{array}$ & 4 & & & $\begin{array}{l}10 \\
10\end{array}$ & 13 & & & 11 & 14 & $\begin{array}{r}6 \\
6 \\
15\end{array}$ & 5 & & $\begin{array}{l}A \\
A \\
A\end{array}$ \\
\hline $\begin{array}{l}07351500 \\
07351600 \\
07351748\end{array}$ & 4 & & & & 16 & & 4 & $\begin{array}{l}11 \\
11\end{array}$ & & $\begin{array}{l}6 \\
6\end{array}$ & 5 & & $\begin{array}{l}A \\
A \\
A\end{array}$ \\
\hline $\begin{array}{l}07351750 \\
07352000 \\
07352800\end{array}$ & $\begin{array}{l}4 \\
4\end{array}$ & 1 & & 17 & & & $\begin{array}{l}4 \\
4\end{array}$ & 11 & & 6 & $\begin{array}{l}5 \\
5\end{array}$ & & $\begin{array}{l}A \\
A, P \\
A\end{array}$ \\
\hline $\begin{array}{l}07354100 \\
07364100 \\
07364200\end{array}$ & 4 & & & 20 & 18 & & $\begin{array}{r}19 \\
4\end{array}$ & & & 6 & $\begin{array}{l}5 \\
5\end{array}$ & 5 & $\begin{array}{l}A \\
A, P, F\end{array}$ \\
\hline $\begin{array}{l}07364890 \\
07366200 \\
07367630\end{array}$ & 4 & & & & $\begin{array}{l}21 \\
22\end{array}$ & & 4 & & & 6 & $\begin{array}{l}5 \\
5\end{array}$ & & $\begin{array}{l}A \\
A \\
A\end{array}$ \\
\hline $\begin{array}{l}07368000 \\
07369000 \\
07369500\end{array}$ & & & & $\begin{array}{l}20 \\
20 \\
20\end{array}$ & & & 3 & & $\begin{array}{l}14 \\
14 \\
14\end{array}$ & $\begin{array}{l}6 \\
6 \\
6\end{array}$ & & & $\begin{array}{l}A \\
A \\
A\end{array}$ \\
\hline $\begin{array}{l}07369700 \\
07370000 \\
07371500\end{array}$ & 4 & & & $\begin{array}{l}20 \\
20\end{array}$ & & & 4 & & 14 & 6 & $\begin{array}{l}5 \\
5\end{array}$ & & $\begin{array}{l}A \\
A, P\end{array}$ \\
\hline $\begin{array}{l}07372200 \\
07373000 \\
07373250\end{array}$ & $\begin{array}{l}4 \\
4 \\
4\end{array}$ & 23 & & & & 2 & $\begin{array}{r}4 \\
23\end{array}$ & & 4 & & $\begin{array}{l}5 \\
5\end{array}$ & & $\begin{array}{l}A, T \\
A \\
A\end{array}$ \\
\hline $\begin{array}{l}07375000 \\
07375500 \\
07376000\end{array}$ & $\begin{array}{l}4 \\
4 \\
4\end{array}$ & & & & & 2 & 3 & & & $\begin{array}{l}15 \\
15 \\
15\end{array}$ & & & $\begin{array}{l}A \\
A \\
A, T\end{array}$ \\
\hline $\begin{array}{l}07376500 \\
07377000 \\
07377240\end{array}$ & $\begin{array}{l}4 \\
4\end{array}$ & & & 24 & & 2 & & & 4 & 15 & 25 & & $\begin{array}{l}A \\
A, T\end{array}$ \\
\hline
\end{tabular}


Table 2.--Use of Louisiana streamf low data--Continued

\begin{tabular}{|c|c|c|c|c|c|c|c|c|c|c|c|c|c|}
\hline \multirow[b]{2}{*}{ Station no. } & \multicolumn{8}{|c|}{ Data Use } & \multicolumn{4}{|c|}{ Funding } & \multirow[b]{2}{*}{$\begin{array}{l}\text { Data } \\
\text { avail- } \\
\text { ability }\end{array}$} \\
\hline & 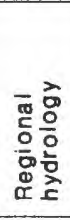 & 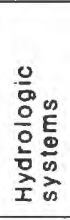 & 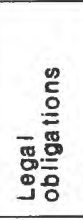 & 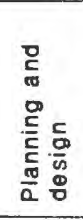 & 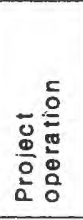 & 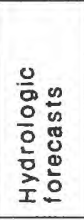 & 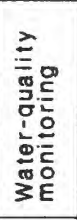 & 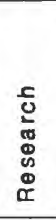 & 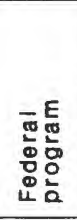 & 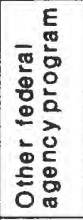 & 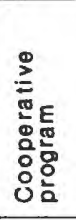 & 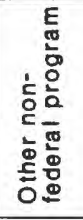 & \\
\hline $\begin{array}{l}07377500 \\
07377755 \\
07377782\end{array}$ & $\begin{array}{l}4 \\
4\end{array}$ & & & $\begin{array}{l}24 \\
24\end{array}$ & & 2 & & & & $\begin{array}{l}15 \\
15\end{array}$ & 5 & & $\begin{array}{l}A, T \\
A \\
A\end{array}$ \\
\hline $\begin{array}{l}07377842 \\
07378000 \\
07378500\end{array}$ & & 1 & & $\begin{array}{l}24 \\
24 \\
24\end{array}$ & & 2 & & & & $\begin{array}{l}15 \\
15\end{array}$ & 5 & & $\begin{array}{l}A \\
A \\
A, P, T\end{array}$ \\
\hline $\begin{array}{l}07380400 \\
07381800 \\
07382000\end{array}$ & 4 & & & & $\begin{array}{l}26 \\
27 \\
28\end{array}$ & & & & & 15 & $\begin{array}{l}5 \\
5\end{array}$ & & $\begin{array}{l}A \\
A \\
A\end{array}$ \\
\hline $\begin{array}{l}07382500 \\
07383500 \\
07385500\end{array}$ & & & & & $\begin{array}{l}29 \\
29 \\
30\end{array}$ & & & & & 15 & $\begin{array}{l}5 \\
5\end{array}$ & & $\begin{array}{l}A \\
A \\
A\end{array}$ \\
\hline $\begin{array}{l}07385700 \\
07386200 \\
07386700\end{array}$ & & & & & $\begin{array}{l}30 \\
30 \\
30\end{array}$ & & 3 & & & 15 & $\begin{array}{l}5 \\
5\end{array}$ & & $\begin{array}{l}A \\
A \\
A\end{array}$ \\
\hline $\begin{array}{l}07386880 \\
08010000 \\
08012000\end{array}$ & $\begin{array}{l}4 \\
4\end{array}$ & & & & 30 & 2 & 4 & & & $\begin{array}{l}15 \\
15 \\
15\end{array}$ & & & $\begin{array}{l}A \\
A \\
A, T\end{array}$ \\
\hline $\begin{array}{l}08013000 \\
08013500 \\
08014500\end{array}$ & $\begin{array}{l}4 \\
4 \\
4\end{array}$ & i & & & & 2 & 4 & & & 15 & $\begin{array}{l}5 \\
5\end{array}$ & & $\begin{array}{l}A, T \\
A, P \\
A\end{array}$ \\
\hline $\begin{array}{l}08015500 \\
08016400 \\
08016800\end{array}$ & $\begin{array}{l}4 \\
4\end{array}$ & & & & & 2 & 3 & & & 15 & $\begin{array}{l}5 \\
5\end{array}$ & & $\begin{array}{l}A_{,} T \\
A \\
A\end{array}$ \\
\hline $\begin{array}{l}08022765 \\
08023080 \\
08023400\end{array}$ & $\begin{array}{l}4 \\
4 \\
4\end{array}$ & & & & & & $\begin{array}{l}4 \\
4\end{array}$ & & & & $\begin{array}{l}5 \\
5 \\
5\end{array}$ & & $\begin{array}{l}A \\
A \\
A\end{array}$ \\
\hline $\begin{array}{l}08025500 \\
08028000\end{array}$ & 4 & & $\begin{array}{l}31 \\
31\end{array}$ & & & & 4 & & & & $\begin{array}{r}5 \\
31\end{array}$ & & $\begin{array}{l}A, P \\
A\end{array}$ \\
\hline
\end{tabular}

1. Long-term index station.

Flood forecasting-U.S. National Weather Service.

National Stream-Quality Accounting Network (NASQAN).

Station is used for only regional hydrology.

Office of Public Works.

. Vickstrict.

Diversions from Red River to Cross Lake for water supply.

Index station for Cross Lake inflow.

inflow and flood control project.

lndex station for Lake Bistineau inflow and flood control project.

Lignite hydrology project.

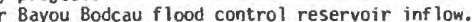

Index station for Cypress Bayou reservoir inf low.

U.S. Army Corps of Engineers replacenent funds.

U.S. Army Corps of Engineers, New Orleans District.

Index station for Wallace Lake inf low.
17. Mutt Fowler Reservoir.

18. Ouachita River Lock and Dam No. 6.

19. Index station for waste-water discharge permit.

20. Ouachita River flood-control projects.

21. Lake Claiborne and Bayou D'Arbonne Lake project.

. Ouachita River Lock and Dam No. 3.

Hydrologic benchmark station.

White Bayou-Comite River-Amite River flood-control project.

25. East Baton

Bayou Lafourche Hater District diversion.

27. Index station for Cocodrie Lake inflow.

29.

30. Bayou Teche and Vermilion 
free of manmade alteration. Two index stations, Saline Bayou near Lucky and Calcasieu River near Oberlin, are also used to indicate current hydrologic conditions. The locations of stream gages that provide information about regional hydrology are given in figure 4 .

\section{Hydrologic Systems}

Stations that can be used for accounting, that is, to define current hydrologic conditions and the sources, sinks, and fluxes of water through hydrologic systems (including regulated systems) are designated as hydrologic-system stations. They include stations that measure diversions and return flows and stations that are useful for defining the interaction of water systems. Five stations are classified as needed for hydrologic systems. Two index stations, Pearl River near Bogalusa, La., and Amite River near Denham Springs, La., also are used to indicate current hydrologic conditions.

\section{Legal Obligations}

Some stations provide records of flows for the verification or enforcement of existing treaties, compacts, and decrees. The legal obligation category contains only those stations that the Survey is required to operate to satisfy a legal responsibility.

Two stations, in particular, in the Louisiana program exists to fulfill a legal responsibility of the Survey.

\section{Planning and Design}

Gaging stations in this category of data use are for the planning and design of a specific project (for example, a dam, levee, floodwall, navigation system, water-supply diversion, hydropower plant, or waste-treatment facility) or group of structures. The planning and design category is limited to those stations that were instituted for such purposes and for which this purpose is still valid.

Sixteen stations in the Louisiana program are being operated for planning or design purposes. Fourteen of these are for continued improvements and upgrading of the levee systems and water-supply diversions. One is being used in the design of a proposed water-supply reservoir.

\section{Project Operation}

Gaging stations in this category are used, on an ongoing basis, to obtain data to aid water managers in making operational decisions such as reservoir releases, hydropower operations, or diversions. Use for project operation generally implies that the data are routinely available to the operators on a rapid-reporting basis. For projects on large streams, data may be needed only every few days. 

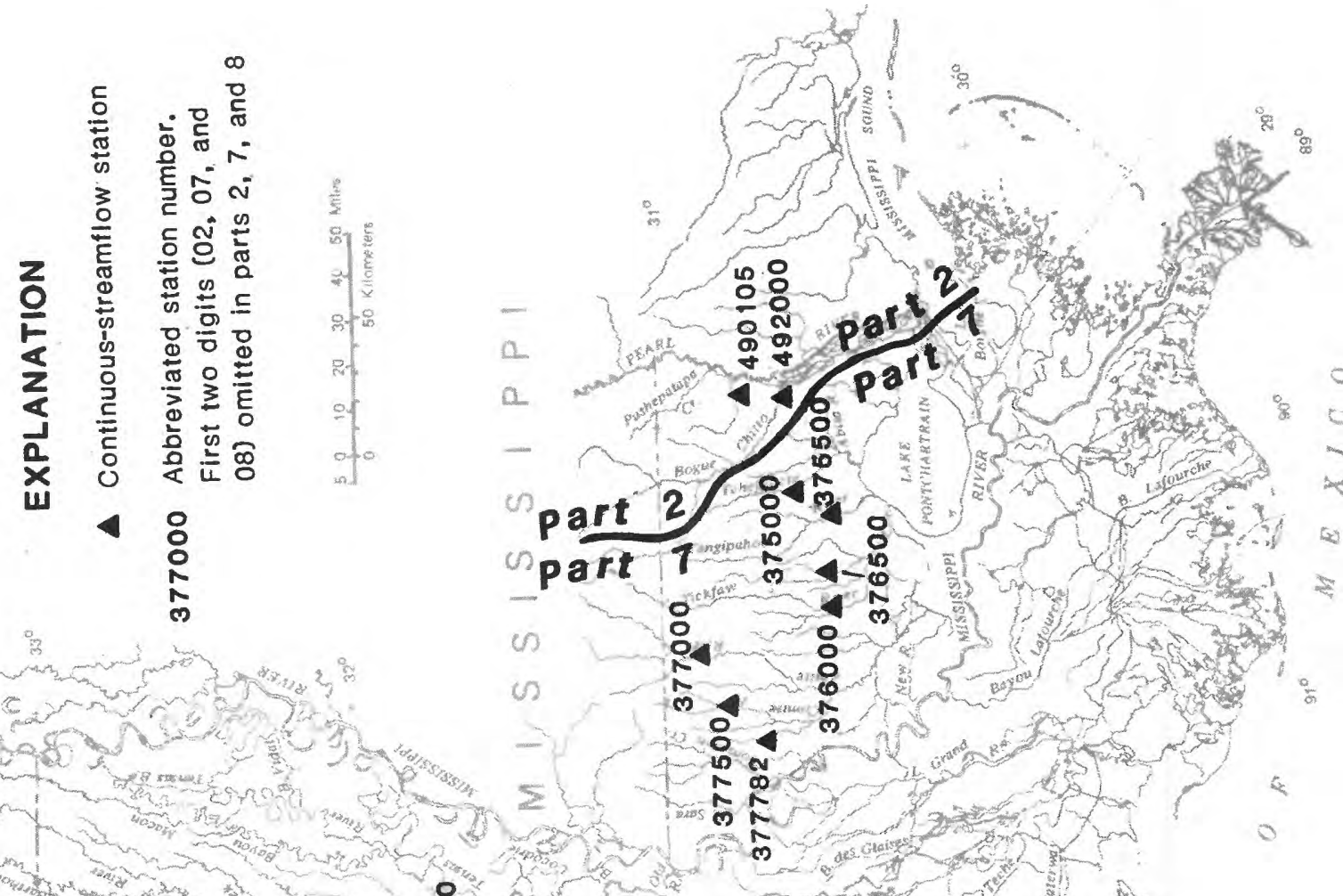

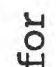
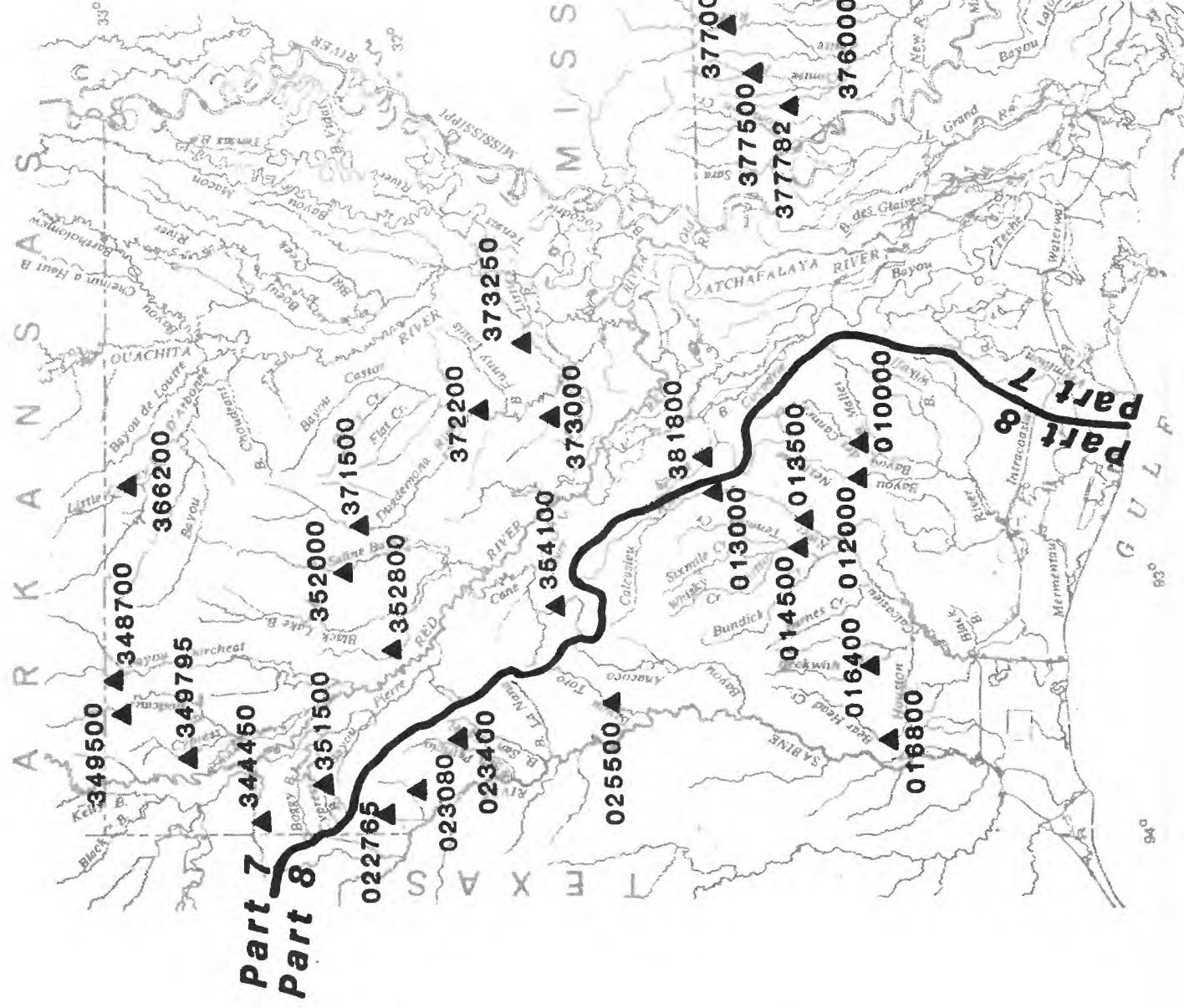
Twenty stations in the Louisiana program are used for project operation. Eighteen of these are used to aid operators in the management of reservoirs and control structures that are part of hydropower-production systems or flood-control systems. One of the remaining stations is used to provide information for the pumping plant operators for the Bayou Lafourche Water District.

\section{Hydrologic Forecasts}

Gaging stations in this category are regularly used to provide information for hydrologic forecasting. These might be flood forecasts for a specific river reach or periodic (daily, weekly, monthly, or seasonal) flow-volume forecasts for a specific site or region. Use for hydrologic forecasts generally implies that the data are routinely available to the forecasters on a rapid-reporting basis. On large streams, data may be needed only every few days.

The nine stations in the Louisiana program that are included in the hydrologic-forecast category are used for flood forecasting and for forecasting inflows to reservoirs. Data are used by the NWS (National Weather Service) and the Flood Forecast Center in Slidell, La.

$$
\text { Water-Quality Monitoring }
$$

Gaging stations, where regular water-quality or sediment-transport monitoring is being conducted and where the availability of streamflow data contributes to the utility of or is essential to the interpretation of the water-quality or sediment data, are designated as water-qualitymonitoring sites.

Twenty-two stations in the program are being operated in conjunction with water-quality monitoring.

One station in the program is a designated bench-mark station and seven are NASQAN (National Stream-Quality Accounting Network) stations. Water-quality data from bench-mark stations are used to describe waterquality characteristics of streams that have been and probably will continue to be relatively free of manmade influence. NASQAN stations are part of a countrywide network designed to assess water-quality trends of significant streams.

\section{Research}

Gaging stations in this category are operated for a particular research or water-investigations study. Typically, these are only operated for a few years, if used solely for a particular study.

Five stations in the Louisiana program are used in support of a research study on lignite mining in northwestern Louisiana. 


\section{Funding}

The four sources of funding for the streamflow-data program are:

1. Federal program.--Funds that have been directly allocated to the U.S. Geological Survey.

2. Other Federal agency program.--Funds that have been transferred to the U.S. Geological Survey by other Federal agencies.

3. Cooperative program.--Funds that come jointly from the U.S. Geological Survey cooperative-designated funding and from a non-Federal cooperating agency. Cooperating-agency funds may be in the form of direct services or cash.

4. Other non-Federal program.--Funds that are provided entirely by a non-Federal agency or a private concern under the auspices of a Federal agency. In this study for Louisiana, there was no funding from private concerns; one station is special because it was supported in part by cooperative funds and in part by non-Federal agency funds. Funds in this category are not matched by U.S. Geological Survey cooperative funds.

In all four sources, the identified sources of funding pertain only to the collection of streamflow data; sources of funding for other activities, particularly the collection of water-quality samples, that might be carried out at the site may not necessarily be the same as those identified herein.

\section{Frequency of Data Availability and Data Use}

Frequency of data availability refers to the frequency at which the streamflow data may be furnished to the users. In this category, three distinct possiblities exist. Data can be furnished in publication format through the annual data report published by the U.S. Geological Survey for Louisiana (U.S. Geological Survey, 1982) or by periodic release of provisional data by direct-access telemetry equipment for immediate use. These three categories are designated $A, P$; and $T$, respectively, in table 2 . In the current Louisiana program, data for al1 68 stations are made available through the annual report. Data from 10 stations are available on a realtime basis; and data for four additional stations are released on a provisional basis.

Data-use and ancillary information are presented for each continuousrecord gaging station in table 2 , which is replete with footnotes to expand the information conveyed. 
A review of the data-use and funding information presented in table 2 indicates that five stations are currently being operated to support a short-term hydrologic study. Flat River near Curtis (07349374), Red Chute Bayou at Sligo (07349860), Bayou Pierre near Grand Bayou (07351600), West Branch Dolet Bayou at Rambin (07351748), and Bayou Pierre near Lake End (07351750) are being operated as part of the lignite mining study. The Red Chute Bayou and Flat River data are also used in the Lake Bistineau flood-control project. Therefore, these two stations should remain in the network. After the lignite study is completed, the West Branch Dolet Bayou and Bayou Pierre near Grand Bayou gages should be discontinued. Bayou Pierre near Lake End should be continued in the network to build a longterm data base for sediment and streamflow within this watershed, as mining might occur sometime in the future.

\section{ALTERNATE METHODS OF DEVELOPING STREAMFLOW INFORMATION}

The second step of the analysis of the stream-gaging program is to investigate alternate methods of providing daily streamflow information in lieu of operating continuous-flow gaging stations. The objective of the analysis is to identify gaging stations where alternative technology, such as flow-routing or statistical methods, will provide information about daily-mean streamflow in a more cost-effective manner than operating a continuous stream gage. No guidelines exist concerning suitable accuracies for particular uses of the data; therefore, judgment is required in deciding whether the accuracy of the daily flows estimated through alternate methods is suitable for the intended purpose. The uses of data for a station will determine whether a site has potential for alternate methods. For example, those stations for which flood hydrographs are required in a real-time sense, such as hydrologic forecasts and project operation, are not candidates for the alternate methods. Likewise, there might be a legal obligation to operate a gaging station that would preclude utilizing alternate methods. The primary candidates for alternate methods are stations that are operated upstream or downstream of other stations on the same stream. The accuracy of the estimated streamflow at these sites may be suitable because of the degree of redundancy of flow information between sites. Similar watersheds, located in the same physiographic and climatic area, also may have potential for alternate methods.

All stations in the Louisiana stream-gaging program were categorized as to their potential for utilization of alternative methods and selected methods were applied at applicable stations. The categorization of gaging stations and the application of the specific methods are described in subsequent sections of this report. This section briefly describes the two alternate methods that were used in the Louisiana analysis and documents why these specific methods were chosen.

Because of the short time frame of this analysis, only two methods were considered. Desirable attributes of a proposed alternative method are: (1) The proposed method should be computer oriented and easy to 
apply, (2) The proposed method should have an available interface with the U.S. Geological Survey WATSTORE (Water Data Storage and Retrieval System) daily values file (Hutchinson, 1975), (3) The proposed method should be technically sound and generally acceptable to the hydrologic community, and (4) The proposed method should permit easy evaluation of the accuracy of the simulated streamflow records. The desirability of the first attribute above is rather obvious. Second, the interface with WATSTORE daily values file is needed to easily calibrate the proposed alternate method. Third, the alternative method selected for analysis must be technically sound or it will not provide data of suitable accuracy. Fourth, the alternative method should provide an estimate of the accuracy of the streamflow to judge the adequacy of the simulated data. The above criteria were used to select two methods--a flow-routing model and multiple-regression analysis.

\section{Description of Flow-Routing Model}

Hydrologic flow-routing methods use the law of conservation of mass and the relationship between the storage in a reach and the outflow from the reach. The hydraulics of the system are not considered. The method usually requires only a few parameters and treats the reach in a lumped sense without subdivision. Generally, the input is a discharge hydrograph at the upstream end of the reach, and the output is a discharge hydrograph at the downstream end. Several different types of hydrologic routing are available such as Muskingum, Modified Pulse, Kinematic Wave, and the unitresponse flow-routing method. The latter method was selected for this analysis and uses two techniques--storage continuity (Sauer, 1973) and diffusion analogy (Keefer, 1974; Keefer and McQuivey, 1974), which are discussed below.

The unit-response method was selected because it fulfilled the criteria noted above. Computer programs for the unit-response method can be used to route streamflow from one or more upstream locations to a downstream location. Downstream hydrographs are produced by the convolution of upstream hydrographs with their appropriate unit-response functions. This method can only be applied at a downstream station where an upstream station exists on the same stream. An advantage of this model is that it can be used for regulated stream systems. Reservoir routing techniques are included in the model so that flows can be routed through reservoirs if the operating rules are known. Calibration and verification of the flow-routing model is achieved using observed upstream and downstream hydrographs and estimates of tributary inflows. The convolution model (Doyle and others, 1983) treats a stream reach as a linear one-dimensional system in which the system output (downstream hydrograph) is computed by multiplying (convoluting) the ordinates of the upstream hydrograph by the unit-response function and lagging them appropriately. The model has the capability of combining hydrographs, multiplying a hydrograph by a ratio, and changing the timing of a hydrograph. Although routing can be accomplished using hourly data, only daily data were used in the analysis for this report. 
Three options are available for determining the unit-response (system) function. Selection of the appropriate option depends primarily upon the variability of wave celerity (traveltime) and dispersion (channel storage) throughout the range of discharges to be routed. Adequate routing of daily flows can usually be accomplished using a single unit-response function (linearization about a single discharge) to represent the system response. However, if the routing coefficients vary drastically with discharge, linearization about a low-range discharge results in overestimated high flows that arrive late at the downstream site; whereas, linearization about a high-range discharge results in low-range flows that are underestimated and arrive too soon. A single unit-response function may not provide acceptable results in such instances. Therefore, the option of multiple linearization (Keefer and McQuivey, 1974), which uses a family of unitresponse functions to represent the system response, is available.

Determination of the system's response to the input at the upstream end of the reach is not the total solution for most flow-routing problems. The convolution process makes no accounting of flow from the intervening area between the upstream and downstream locations. Such flows may be totally unknown or estimated by some combination of gaged and ungaged flows. An estimating technique that should prove satisfactory in many instances is the multiplication of known flows at an index gaging station by a factor (for example, a drainage-area ratio).

The objective in either the storage-continuity or diffusion-analogy flow-routing method is to calibrate two parameters that describe the storage-discharge relationship in a given reach and the traveltime of flow passing through the reach. In the storage-continuity method, a response function is derived by modifying a translation-hydrograph technique developed by Mitchell (1962) to apply to open channels. A triangular pulse (Sauer, 1973) is routed through reservoir-type storage and then transformed by a summation-curve technique to a unit response of desired duration. The two parameters that describe the routing reach are $K_{s}$, a storage coefficient that is the slope of the storage-discharge relation, and $W_{S}$, the translation hydrograph time base. These two parameters determine the shape of the resulting unit-response function.

In the diffusion-analogy theory (Keefer and McQuivey, 1974), the two parameters requiring calibration in this method are $K_{0}$, a wave dispersion or damping coefficient, and $C_{0}$, the floodwave celerity. $K_{0}$ controls the spreading of the wave (analogous to $K_{S}$ in the storage-continuity method), and $C_{0}$ controls the traveltime (analogous to $W_{S}$ in the storage-continuity method). In the single linearization method, only one set of $K_{0}$ and $C_{0}$ values is used. In the multiple-linearization method, $C_{0}$ and $K_{0}$ are varied with discharge so a table of wave celerity, $C_{0}$, versus discharge, $Q$, and a table of dispersion coefficient, $K_{0}$, versus discharge, $Q$, are used. 
In both the storage-continuity and diffusion-analogy methods, the two parameters are calibrated by trial and error. The analyst must decide if suitable parameters have been derived by comparing the simulated discharge to the observed discharge.

\section{Description of Regression Analysis}

Simple- and multiple-regression techniques also can be used to estimate daily-flow records. Regression equations can be computed that relate daily flows (or their logarithms) at a single station to daily flows at a combination of upstream, downstream, and (or) tributary stations. This statistical method is not limited, as is the flow-routing method, to stations where an upstream station exists on the same stream. The explanatory variables in the regression analysis can be stations from different watersheds or downstream and tributary watersheds. The regression method has many of the same attributes as the flow-routing method in that it is easy to apply, provides indices of accuracy, and is generally accepted as a good tool for estimation. The theory and assumptions of regression analysis are described in several textbooks such as Draper and Smith (1966) and Kleinbaum and Kupper (1978). The application of regression analysis to hydrologic problems is described and illustrated by Riggs (1973) and Thomas and Benson (1970). Only a brief description of regression analysis is provided in this report.

A linear-regression model of the following form was developed for estimating daily-mean discharges in Louisiana:

$$
y_{i}=B_{0}+\sum_{j=1}^{p} B_{j} x_{j}+e_{i}
$$

where

$$
\begin{gathered}
y_{i}=\text { daily-mean discharge at station } i \text { (dependent variable); } \\
x_{j}=\text { daily-mean discharges at nearby stations (explanatory } \\
\text { variables); }
\end{gathered}
$$

$\mathrm{B}_{\mathrm{O}}$ and $\mathrm{B}_{\mathrm{j}}=$ regression constant and coefficients, respectively; and

$$
\mathrm{e}_{\mathbf{i}}=\text { the random error term. }
$$

The above equation is calibrated ( $B_{0}$ and $B_{j}$ are estimated) using observed values of $y_{j}$ and $x_{j}$. These observed daily-mean discharges can be retrieved from the WATSTORE daily values file. The values of $x_{j}$ may be discharges observed on the same day as discharges at station $i$ or may be for previous or future days, depending on whether station $j$ is upstream or downstream of station $i$. Once the equation is calibrated and verified, future values of $y_{i}$ are estimated using observed values of $x_{j}$. The regression constant and coefficients $\left(B_{0}\right.$ and $\left.B_{j}\right)$ are tested to determine if 
they are significantly different from zero. A given station $j$ should only be retained in the regression equation if its regression coefficient, $B_{j}$, is significantly different from zero. The regression equation should be calibrated using one period of time and then verified or tested for a different period of time to obtain a measure of the true predictive accuracy. Both the calibration and verification period should be representative of the range of flows that could occur at station $i$. The equation should be verified by (1) plotting the residuals $e_{j}$ (difference between simulated and observed discharges) against the dependent and all explanatory variables in the equation and by (2) plotting the simulated and observed discharges versus time. These tests are intended to determine whether (1) the linear model is appropriate or some transformation of the variables is needed, and whether (2) there is any bias in the equation such as overestimating low flows. These tests might indicate, for example, that a logarithmic transformation is desirable, that a nonlinear regression equation is appropriate, or that the regression equation is biased in some way. In this report, these tests indicated that a linear model with a logarithmic transformation of $y_{j}$ and $x_{j}$, in cubic feet per second, was appropriate. The application of linear-regression techniques to one watershed in Louisiana is described in a subsequent section of this report.

It should be noted that the use of a regression relation to synthesize data at a discontinued gaging station entails a reduction in the variance of the streamflow record relative to that which would be computed from an actual record of streamflow at the site. The reduction in variance, expressed as a fraction, is approximately equal to one minus the square of the correlation coefficient that results from the regression analysis.

\section{Categorization of Stream Gages by Their Potential for Alternate Methods}

Five streams where either the flood-routing or regression techniques were considered are Bayou Pierre, Bayou Macon, Amite River, Comite River, and the Calcasieu River. Each has two or more streamflow stations in operation. The Bayou Pierre and Bayou Macon stations were not used in the alternative-methods analysis because one station on each stream is affected by variable backwater. The Amite and Comite Rivers were not used because all stations on the streams are needed for forecasting, and alternative methods would be unacceptable.

\section{Calcasieu River Flow-Routing Analysis}

The purpose of this flow-routing analysis is to investigate the potential for use of the unit-response method for streamflow routing to simulate daily-mean discharges at Calcasieu River near Oberlin (08013500). A schematic diagram of the Calcasieu River study area is presented in figure 5. In this application, a best-fit flow model for the entire flow range is the desired product. Streamflow data available for this analysis are summarized in table 3 . 


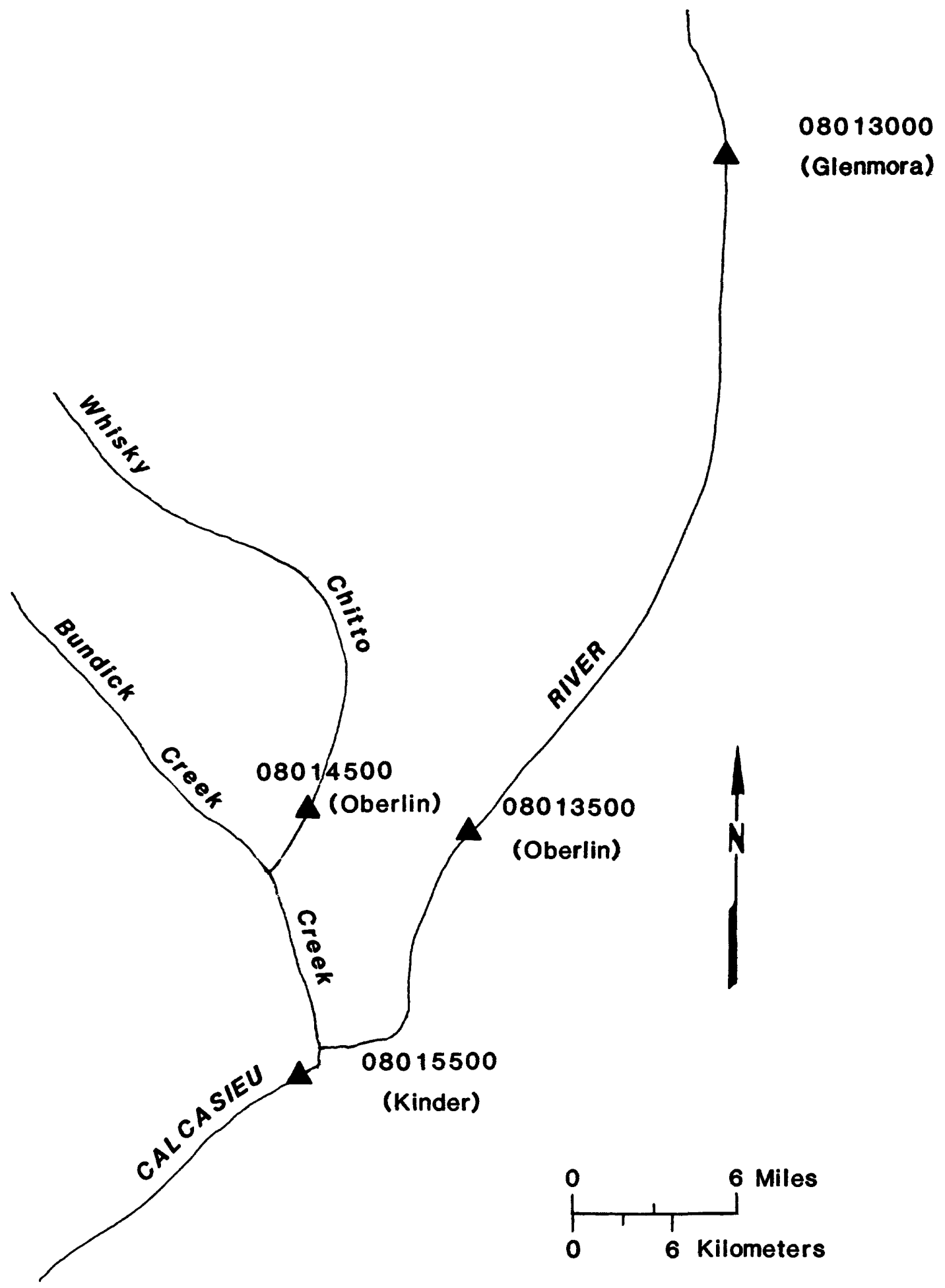

Figure 5.--Continuous-streamflow stations in the Calcasieu River study area. 
Table 3.--Gaging stations used in the Calcasieu River flow-routing study, Louisiana

\begin{tabular}{|c|c|c|c|}
\hline $\begin{array}{l}\text { Station } \\
\text { number }\end{array}$ & Station name & $\begin{array}{c}\text { Drainage } \\
\text { area } \\
\text { (square miles) }\end{array}$ & $\begin{array}{l}\text { Period } \\
\text { of } \\
\text { record }\end{array}$ \\
\hline $\begin{array}{l}08013000 \\
08013500\end{array}$ & $\begin{array}{l}\text { Calcasieu River near Glenmora---- } \\
\text { Calcasieu River near Oberlin-- }\end{array}$ & $\begin{array}{l}499 \\
753\end{array}$ & $\begin{array}{l}8 / 43- \\
8 / 22-1 / 25 \\
9 / 38-\end{array}$ \\
\hline $\begin{array}{l}08014500 \\
08015500\end{array}$ & $\begin{array}{l}\text { Whisky Chitto near Oberlin- } \\
\text { Calcasieu River near Kinder- }\end{array}$ & $\begin{array}{r}510 \\
1,700\end{array}$ & $\begin{array}{l}1 / 39- \\
8 / 22-1 / 25 \\
10 / 38-9 / 57 \\
10 / 61-\end{array}$ \\
\hline
\end{tabular}

The Oberlin gage is located $27.8 \mathrm{mi}$ downstream from the upstream gage at Glenmora. The intervening drainage area between Glenmora and Oberlin is $254 \mathrm{mi}^{2}$ or 33.7 percent of the total drainage area contributing to the oberlin site. There are no streamflow gaging stations located within this $254 \mathrm{mi}^{2}$ intervening area.

To simulate the daily-mean discharges, the analysis routed the flow from Glenmora to Oberlin using the diffusion-analogy method with a single linearization. The intervening drainage area was accounted for by using the streamflow data for the station Whisky Chitto near Oberlin adjusted by a drainage-area ratio. The total discharge at Oberlin was the summation of the routed discharge from Glenmora and the adjusted discharge from Whisky Chitto.

To route flow from Glenmora, it was necessary to determine the model parameters $C_{0}$ (floodwave celerity) and $K_{0}$ (wave dispersion coefficient). The coefficients $C_{0}$ and $K_{0}$ are functions of channel width, $W_{0}$, in feet, channel slope, $S_{0}$, in feet per feet, the slope of the stage discharge relation, $\mathrm{dQ}_{0} / \mathrm{dY}_{0}$, in square feet per second, and the discharge, $\mathrm{Q}_{0}$, in cubic feet per second representative of the reach under study and are determined as follows:

$$
\begin{aligned}
& C_{0}=\frac{1}{W_{0}} \frac{d Q_{0}}{d Y_{0}} \\
& K_{0}=\frac{Q_{0}}{2 S_{0} W_{0}}
\end{aligned}
$$

The discharge, $Q_{0}$, for which initial values of $C_{0}$ and $K_{0}$ were linearized, was the average discharge for the oberlin station. The channel width, $W_{0}$, was calculated from discharge measurements. Channel slope, $\mathrm{S}_{0}$, was obtained by taking the difference between the elevation of zero gage height for Glenmora and Oberlin divided by the reach length. The slope of the stage-discharge relationship, $\mathrm{dQ}_{0} / \mathrm{dY}_{0}$, was determined from the latest rating curve at each gage by using a l-foot increment that 
bracketed the average discharge, $Q_{0}$. The difference in the discharge throughout the 1-foot increment then represents the slope of the function at that point. The model parameters, as determined above, are listed in table 4 .

Table 4.-- Selected reach characteristics used in the Calcasieu River flow-routing study, Louisiana

$\left[Q_{0}\right.$, discharge; $W_{0}$, width; $S_{0}$, channel slope; $\mathrm{dQ}_{0} / \mathrm{dY}_{0}$, slope of stage discharge relation; $C_{0}$, floodwave celerity; $K_{0}$, wave dispersion coefficient]

\begin{tabular}{|c|c|c|c|c|c|c|}
\hline Site & $\begin{array}{c}Q_{0} \\
\text { (cubic } \\
\text { feet per } \\
\text { second) }\end{array}$ & $\begin{array}{c}W_{0} \\
(\text { feet })\end{array}$ & $\begin{array}{c}\mathrm{S}_{0} \\
\text { (feet } \\
\text { per } \\
\text { feet) }\end{array}$ & $\begin{array}{l}\mathrm{dQ}_{0} / \mathrm{dY} \mathrm{O}_{0} \\
\text { (square } \\
\text { feet per } \\
\text { second) }\end{array}$ & $\begin{array}{c}C_{0} \\
\text { (feet } \\
\text { per } \\
\text { second) }\end{array}$ & $\begin{array}{c}\mathrm{K}_{0} \\
\text { (square } \\
\text { feet per } \\
\text { second) }\end{array}$ \\
\hline $\begin{array}{l}\text { Glenmora-- } \\
\text { Oberlin- }\end{array}$ & $\begin{array}{r}700 \\
1,120\end{array}$ & $\begin{array}{l}170 \\
135\end{array}$ & 0.000486 & $\begin{array}{l}342 \\
327\end{array}$ & $\begin{array}{l}2.02 \\
2.42\end{array}$ & $\begin{array}{l}4,240 \\
8,530\end{array}$ \\
\hline
\end{tabular}

For the first routing trial, average values for the model parameters, $C_{0}=2.22 \mathrm{ft} / \mathrm{s}$ and $K_{0}=6,380 \mathrm{ft}^{2} / \mathrm{s}$, were used. To simulate the intervening drainage area of $254 \mathrm{mi}^{2}$, an analysis was made of the general characteristics of the basins involved. These characteristics were then compared to those of the nearest streamflow station, Whisky Chitto near oberlin. A drainage-area ratio, calculated by dividing the difference between drainage areas for Glenmora and Oberlin by the drainage area for Whisky Chitto $(254 / 510=0.5)$, was applied to flows at the Whisky Chitto gage to simulate input from this part of the ungaged intervening drainage.

Several trials were made adjusting the values of $C_{0}, K_{0}$, and the drainage-area adjustment factor. The best-fit single-linearization model was determined to be that with a $C_{0}=2.22 \mathrm{ft} / \mathrm{s}, K_{0}=6,380 \mathrm{ft}^{2} / \mathrm{s}$ and a drainage-area adjustment ratio of 0.5. A summary of the percentage error in simulation of mean-daily discharges at oberlin for water year 1982 is given in table 5 .

Table 5.--Results of routing model for Oberlin station, Louisiana

$\begin{aligned} \text { Mean absolute error for } 365 \text { days } & =64.8 \text { percent } \\ \text { Mean negative error for } 106 \text { days } & =-30.3 \text { percent } \\ \text { Mean positive error for } 259 \text { days } & =78.9 \text { percent } \\ \text { Total volume error } & =-2.4 \text { percent }\end{aligned}$

4 percent of the total observations had errors

13 percent of the total observations had errors

20 percent of the total observations had errors

24 percent of the total observations had errors

28 percent of the total observations had errors

72 percent of the total observations had errors

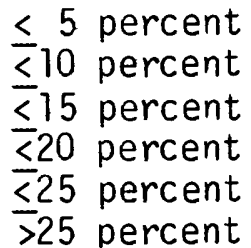


For comparison, the observed and simulated discharges for the oberlin gage during a significant runoff event are shown in figure 6 . The observed and simulated discharges for the Oberlin gage during a late summer low-flow period can be compared in figure 6 .
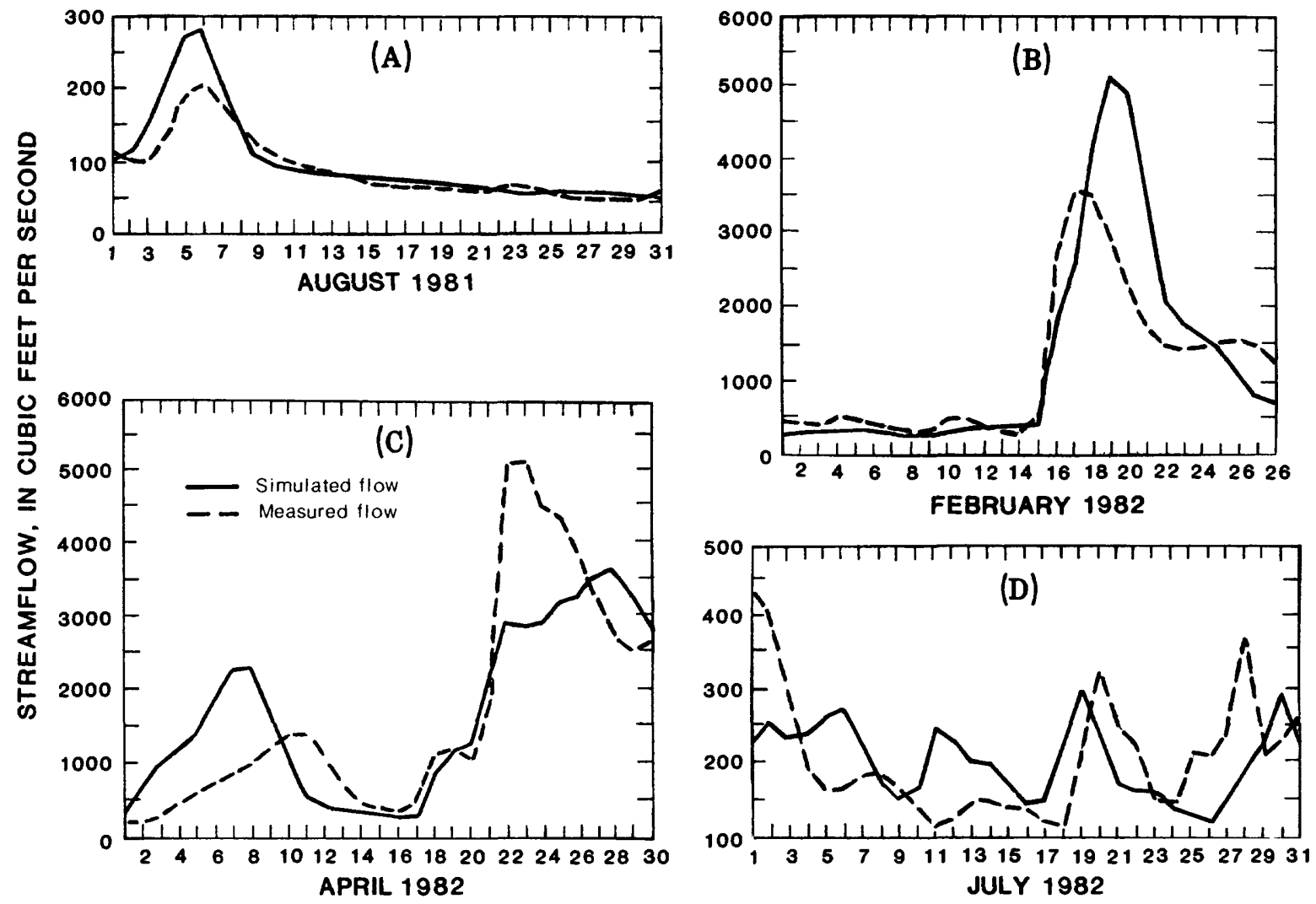

Figure 6.--Daily hydrographs, Calcasieu River near Oberlin, Louisiana.

\section{Regression Analysis Results}

Linear-regression techniques were applied to Calcasieu River near oberlin in this study. The streamflow record for the station considered for simulation (the dependent variable) was regressed against streamflow records at other stations (explanatory variables) during a given period of record (the calibration period). Best-fit linear-regression models were developed and used to provide a daily-streamflow record that was compared to the observed streamflow record. The percentage difference between the simulated and actual record for each day was calculated. The results of the regression analysis for the site are summarized in table 6 . The streamflow record at Calcasieu River near Oberlin was not reproduced with an acceptable degree of accuracy using regression techniques. (See fig. 6.) The simulated data were within 10 percent of the actual record only 27 percent of the time during the calibration period (Oct. 1, 1980-Sept. 30, 1982). These results occurred when daily-mean discharge at Calcasieu 
Table 6.--Summary of calibration for regression modeling of mean daily streamf Tow at Calcasieu River near Oberlin, Louisiana (08013500)

\begin{tabular}{|c|c|c|c|c|c|}
\hline \multirow[t]{2}{*}{ Model } & \multicolumn{5}{|c|}{$\begin{array}{c}\text { Percentage of simulated flow } \\
\text { within indicated percentage } \\
\text { of actual flow }\end{array}$} \\
\hline & 5 & 10 & 15 & 20 & 25 \\
\hline $\begin{array}{c}Q_{13500=-}=0.716+0.575 \log \operatorname{lag}_{2} Q_{13000} \\
+0.759 \log Q_{14500}\end{array}$ & 13 & 27 & 39 & 48 & 57 \\
\hline$Q_{13500}=-76.4+0.460 Q_{15500}$ & 9 & 21 & 32 & 40 & 47 \\
\hline $\begin{array}{c}Q_{13500=}-56.9+0.568 Q_{15500} \\
-0.355 Q_{14500}\end{array}$ & 10 & 21 & 31 & 40 & 48 \\
\hline
\end{tabular}

River near Glenmora and Whisky Chitto near Oberlin were used as the explanatory variables. Streamflows for the Glenmora station were lagged 2 days to take into account time of travel. The explanatory variables were transformed to logarithmic values and then used in the linear-regression method. Results were better using the logarithmic transformation of the streamflow data than using non-transformed data for this particular linear-regression model.

Other combinations of explanatory variables were used in the regression technique to simulate streamflow for Calcasieu River near Oberlin. For instance, streamflow for Calcasieu River near Kinder was used as the only explanatory variable, and this station also was used in combination with Whisky Chitto near Oberlin. These two models did not improve the simulation of streamflow for Calcasieu River near Oberlin. (See table 6.)

\section{Conclusions Pertaining to Alternative Methods of Data Generation}

The simulated data from both the flow-routing and regression methods for the Calcasieu River near Oberlin station were not sufficiently accurate to use these methods in lieu of operating a continuous-flow stream gage. af these two methods, the regression method provided the better results. For the flow-routing method, 13 percent of all the simulated discharges were within 10 percent of the actual discharge. With the regression method, 27 percent of all the simulated discharges were within 10 percent of the actual discharge. This gage needs to remain in operation as part of the Louisiana stream-gaging program. 
Introduction to Kalman-Filtering For Cost-Effective Resource Allocation

In a study of the cost effectiveness of a network of stream gages operated to determine water consumption in the lower Colorado River basin, a set of techniques called K-CERA, (Kalman-Filtering for Cost-Effective Resource Allocation), were developed (Moss and Gilroy, 1980). Because of the water-balance nature of that study, the measure of effectiveness of the network was chosen to be the minimization of the sum of variances of errors of estimation of annual-mean discharges at each site in the network. This measure of effectiveness tends to concentrate stream-gaging resources on the larger, less stable streams where potential errors are greatest. While such a tendency is appropriate for a water-balance network, in the broader context of the multitude of uses of the streamflow data collected in the Survey streamflow information program, this tendency causes undue concentration on larger streams. Therefore, the original version of K-CERA was extended to include as optional measures of effectiveness the sums of the variances of errors in estimating the following streamflow variables: annual-mean discharge, in cubic feet per second; annual-mean discharge, in percentage; average-instantaneous discharge, in cubic feet per second; or average-instantaneous discharge, in percentage. The use of percentage errors does not unduly weight activities at large streams to the detriment of records on small streams. In addition, the instantaneous discharge is the basic variable from which all other streamflow data are derived. For these reasons, this study used the K-CERA techniques with the sums of the variances of the percentage errors of the instantaneous discharges at all continuously gaged sites as the measure of the effectiveness of the data-collection activity.

The original version of K-CERA also failed to account for error contributed by missing stage or other correlative data that are used to compute streamflow data. The probabilities of missing correlative data increase as the period between service visits to a stream gage increases. A procedure for dealing with the missing record has been developed and was incorporated into this study.

Brief descriptions of the mathematical program used to optimize cost effectiveness of the data-collection activity and of the application of Kalman filtering (Gelb, 1974) to the determination of the accuracy of a stream-gaging record are presented below. For more detail on either the theory or the applications of K-CERA, see Moss and Gilroy (1980) and Gilroy and Moss (1981).

\section{Description of Mathematical Program}

The program, "The Traveling Hydrographer," attempts to allocate among stream gages a predefined budget for the collection of streamflow data in such a manner that the field operation is the most cost effective possible. The measure of effectiveness was discussed in the previous section. The set of decisions available to the manager is the various frequencies of use (number of times per year) of each of a number of 
routes that may be followed to service the stream gages and to make discharge measurements. The range of options within the program is from zero usage to daily usage for each route. A route is defined as a set of one or more stream gages and the least-cost travel that takes the hydrographer from his base of operation to each of the gages and back to the base. A route will have associated with it an average cost of travel and average cost of servicing each stream gage visited along the way. The first step in this part of the analysis is to define the set of practical routes. This set of routes frequently will contain the path to an individual stream gage, with that gage as the only stop and return to home base so that the individual needs of a stream gage can be considered in isolation from the other gages.

Another step in this part of the analysis is the determination of any special requirements for visits to each of the stations for such things as necessary periodic maintenance of the recording equipment or required periodic collection of water-quality samples. Such special requirements are considered to be inviolable constraints in terms of the minimum number of visits to each gage.

The final step is to use all of the above to determine the number of times, $N_{i}$, that the $i$ th route for $i=1,2, \ldots, N$, where $N R$ is the number of practical routes, is used during a year such that (1) the budget for the network is not exceeded, (2) the minimum number of visits to each station is made, and (3) the total uncertainty in the network is minimized. Figure 7 represents this step in the form of a mathematical program and figure 8 presents a tabular layout of the problem. Each of the NR routes is represented by a row of the table and each of the stations is represented by a column. The zero-one matrix, $\left(\omega_{i j}\right)$, defines the routes in terms of the stations that compose it. A value of one in row $i$ and column $j$ indicates that gaging station $j$ will be visited on route $i$; a value of zero indicates that it will not. The unit-travel costs, $B i$, are the per-trip costs of the hydrographer's travel time and any related per diem and operation, maintenance, and rental costs of vehicles. The sum of the products of $\mathrm{B}_{i}$ and $\mathrm{Ni}$ for $\mathrm{i}=1,2, \ldots, \mathrm{NR}$ is the total travel cost associated with the set of decisions $\underline{N}={ }^{\prime} \dot{N}_{1}$, $N_{2}$, ..., $N_{N R}$ ).

The unit-visit cost, $\alpha_{j}$, comprises the average service and maintenance costs incurred on a visit to the station plus the average cost of making a discharge measurement. The set of minimum visit constraints is denoted by the row $\lambda j, j=1,2, \ldots$, MG, where $M G$ is the number of stream gages. The row of integers $M_{j}, j=1,2, \ldots$, MG specifies the number of visits to each station. $M_{j}$ is the sum of the products of wij and $N_{j}$ for all $i$ and must equal or exceed $\lambda_{j}$ for all $j$ if $\underline{N}$ is to be a feasible solution to the decision problem.

The total cost expended at the stations is equal to the sum of the products of $\alpha_{j}$ and $M_{j}$ for all $j$. The cost of record computation, documentation, and publication is assumed to be influenced negligibiy by. the number of visits to the station and is included along with overhead in the fixed cost of operating the network. The total cost of operating the network equals the sum of the travel costs, the at-site costs, and the fixed cost and must be less than or equal to the available budget. 


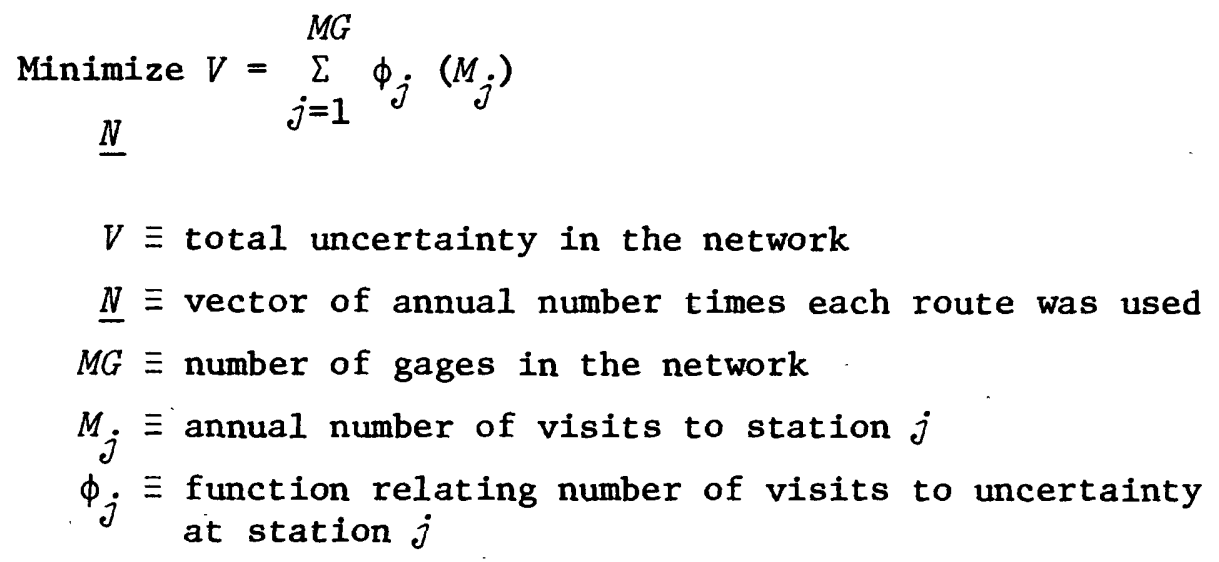

Such that

$$
\begin{aligned}
& \text { Budget } \geq T_{c} \equiv \text { total cost of operating the network } \\
& \text { MG } \quad N R \\
& T_{c}=F_{c}+\sum_{j=1} \alpha_{j} M_{j}+\sum_{i=1} \beta_{i} N_{i} \\
& F_{c} \equiv \text { fixed cost } \\
& \alpha_{j} \equiv \text { unit cost of visit to station } j \\
& N R \equiv \text { number of practical routes chosen } \\
& \beta_{i} \equiv \text { travel cost for route } i \\
& N_{i} \equiv \text { annual number times route } i \text { is used } \\
& \text { (an element of } \underline{N} \text { ) }
\end{aligned}
$$

and such that

$$
\begin{aligned}
M_{j} \geq & \lambda_{j} \\
& \lambda_{j} \equiv \text { minimum number of annual visits to station } j
\end{aligned}
$$

Figure 7.--Mathematical-programming form of the optimization of the routing of hydrographers.

The total uncertainty in the estimates of discharges at the MG stations is determined by summing the uncertainty functions, $\phi_{j}$, evaluated at the value of $M_{j}$ from the row above it, for $j=1,2, \ldots, M G$.

As pointed out in Moss and Gilroy (1980), the steepest descent search used to solve this mathematical program does not guarantee a true optimum solution. However, the locally optimum set of values for $\mathbb{N}$ obtained with this technique specify an efficient strategy for operating the network, which may be the true optimum strategy. The true optimum cannot be guaranteed without testing all undominated, feasiole strategies. 


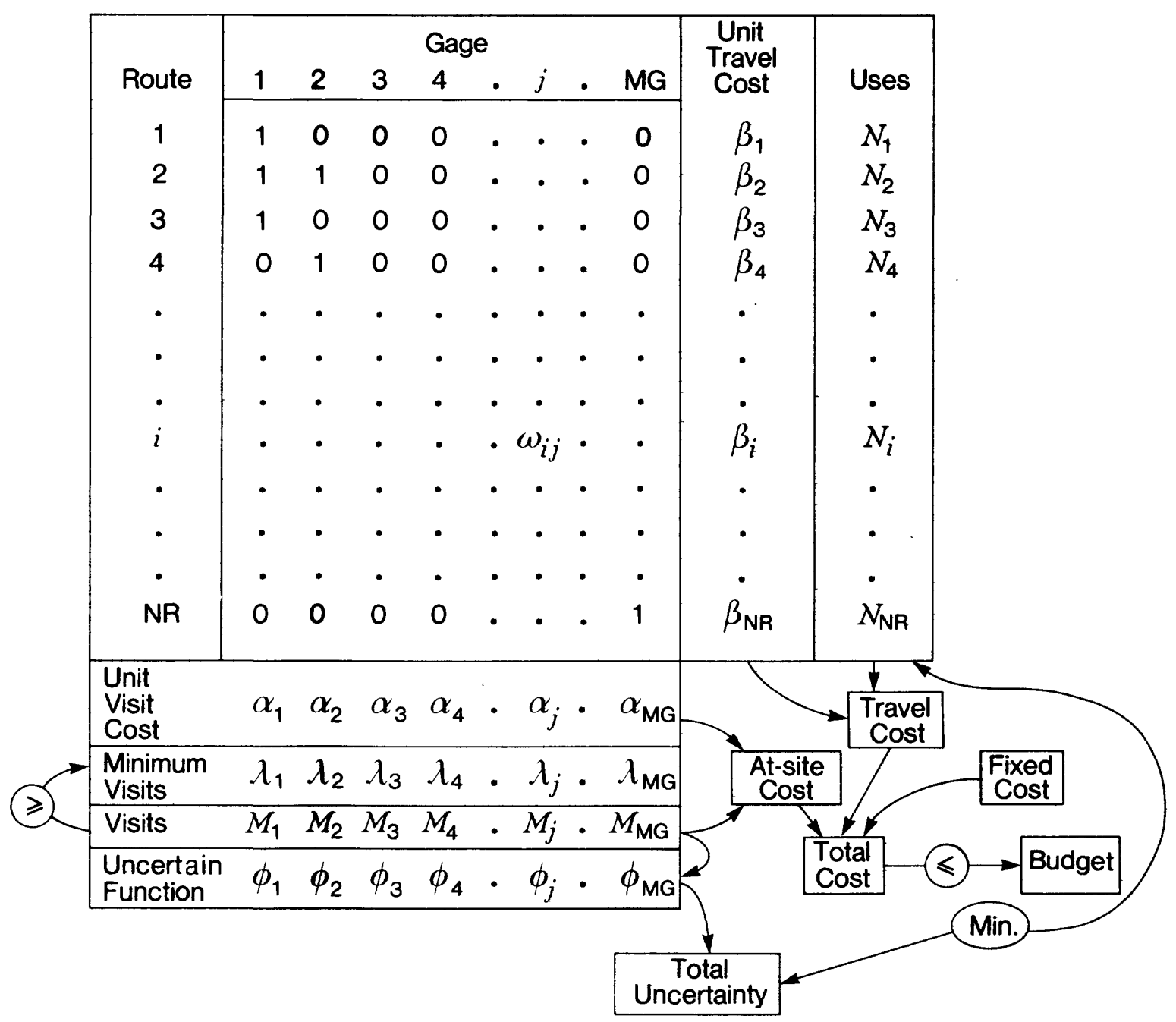

Figure 8.--Tabular form of the optimization of the routing of hydrographers.

\section{Description of Uncertainty Functions}

As noted earlier, uncertainty in streamflow records is measured in this study as the average relative variance of estimation of instantaneous discharges. The accuracy of a streamflow estimate depends on how that estimate was obtained. Three situations are considered in this study: (1) streamflow is estimated from measured discharge and correlative data using a stage-discharge relation (rating curve), (2) the streamflow record is reconstructed using secondary data at nearby stations because primary correlative data are missing, and (3) primary and secondary data are unavailable for estimating streamflow. The variances of the errors of the 
estimates of flow that would be employed in each situation were weighted by the fraction of time each situation is expected to occur. Thus, the average relative variance would be

with

$$
\bar{V}=\varepsilon_{f} V_{f}+\varepsilon_{r} V_{r}+\varepsilon_{e} V_{e}
$$

where

$$
1=\varepsilon_{f}+\varepsilon_{r}+\varepsilon_{e}
$$

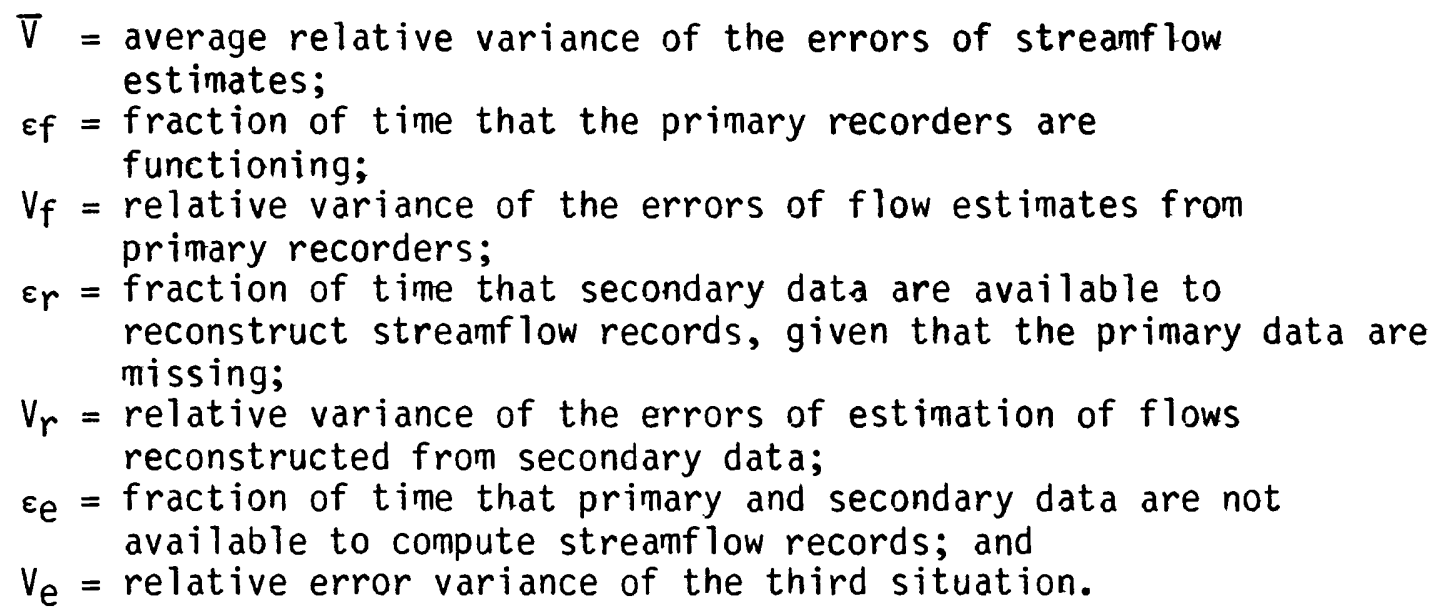

The fractions of time that each source of error is relevant are functions of the frequencies at which the recording equipment is serviced.

The time, $\tau$, since the last service visit until failure of the recorder or recorders at the primary site is assumed to have a negative exponential-probability distribution truncated at the next service time; the distribution's probability density function is

$$
f(\tau)=k e^{-k \tau} /\left(1-e^{-k s}\right)
$$

where

$$
\begin{aligned}
& \mathrm{k}=\text { failure rate in units of (day) }-1, \\
& \mathrm{e}=\text { base of natural logarithms, and } \\
& \mathrm{s}=\text { interval between visits to the site in days. }
\end{aligned}
$$

It is assumed that, if a recorder fails, it continues to malfunction until the next service visit. As a result,

$$
\varepsilon_{f}=\left(1-e^{-k s}\right) /(k s)
$$

(Fontaine and others, 1983, eq. 21).

The fraction of time, $\varepsilon_{e}$, that no records exist at either the primary or secondary sites also can be derived assuming that the time between failures at both sites is independent and has negative exponential distributions with the same rate constant. It then follows that 


$$
\varepsilon_{e}=1-\left[2\left(1-e^{-k s}\right)-0.5\left(1-e^{-2 k s}\right)\right] /(k s)
$$

(Fontaine and others, 1983, eqs. 23 and 25).

Finally, the fraction of time, $\varepsilon_{r}$, that records are reconstructed based on data from a secondary site is determined by the equation

$$
\varepsilon_{r}=1-\varepsilon_{f}-\varepsilon_{e}=\left[\left(1-e^{-k s}\right)-0.5\left(1-e^{-2 k s}\right)\right] /(k s) .
$$

The relative variance, $V_{f}$, of the error derived from primary record computation is determined by analyzing a time series of residuals that are the differences between the logarithms of measured discharge and the rating curve discharge. The rating curve discharge is determined from a relationship between discharge and some correlative data, such as water-surface elevation at the gaging station. The measured discharge is the discharge determined by field observations of depths, widths, and velocities. Let $q_{T}(t)$ be the true instantaneous discharge at time, $t$, and let $q_{R}(t)$ be the value that would be estimated using the rating curve. Then

$$
x(t)=\ln q_{T}(t)-\ln q_{R}(t)=\ln \left[q_{T}(t) / q_{R}(t)\right]
$$

is the instantaneous difference between the logarithms of the true discharge and the rating curve discharge.

In computing estimates of streamflow, the rating curve may be continually adjusted on the basis of periodic measurements of discharge. This adjustment process results in an estimate, $q_{c}(t)$, that is a better estimate of stream discharge at time, $t$. The difference between the variable $\hat{x}(t)$, which is defined as

$$
\hat{x}(t)=\ln q_{c}(t)-\ln q_{R}(t)
$$

and $x(t)$ is the error in the streamflow record at time, $t$. The variance of this difference over time is the desired estimate of $v_{f}$.

Unfortunately, the true instantaneous discharge, $q_{T}(t)$, cannot be determined and, thus, $x(t)$ and the difference, $\hat{x}(t)-x(t)$, cannot be determined either. However, the statistical properties of $\hat{x}(t)-x(t)$, particularly its variance, can be inferred from the available discharge measurements. Let the observed residuals of measured discharge from the rating curve be $z(t)$ so that

$$
z(t)=x(t)+v(t)=\ln q_{m}(t)-\ln q_{R}(t)
$$

where

$v(t)=$ measurement error, and in $q_{m}(t)=\begin{aligned} & \text { logarithm of the measured discharge equal to in } \\ & v(t)\end{aligned}$

In the Kalman-filtering analysis, the $z(t)$ time series was analyzed to determine three site-specific parameters. The Kalman filtering used in this study assumes that the time residuals $x(t)$ arise from a continuous first-order Markovian process that has a Gaussian (normal) probability dis- 
tribution with zero mean and variance (subsequently referred to as process variance) equal to $p$. A second important parameter is $B$, the reciprocal of the correlation time of the Markovian process giving rise to $x(t)$; the correlations between $x\left(t_{1}\right)$ and $x\left(t_{2}\right)$ is $\exp \left[-\beta\left|t_{1}-t_{2}\right|\right]$. Fontaine and others (1983) also defined $q$, the constant value of the spectral density function of the white noise which drives the Gauss-Markov x-process. The parameters, $p, q$, and $B$ are related by

$$
\operatorname{Var}[x(t)]=p=q /(2 B)
$$

The variance of the observed residuals $z(t)$ is

$$
\operatorname{Var}[z(t)]=p+r
$$

where $r$ is the variance of the measurement error, $v(t)$. The three parameters, $p, B$, and $r$, are computed by analyzing the statistical properties of the $z(t)$ time series. These three site-specific parameters are needed to define this component of the uncertainty relationship. The Kalman filtering utilizes these three parameters to determine the average relative variance of the errors of estimation of discharges as a function of the number of discharge measurements per year (Moss and Gilroy, 1980).

If the recorder at the primary site fails and there are no concurrent data at other sites that can be used to reconstruct the missing record at the primary site, there are at least two ways of estimating discharges at the primary site. A recession curve could be applied from the time of recorder stoppage until the gage was once again functioning or the expected value of discharge for the period of missing data could be used as an estimate. The expected-value approach is used in this study to estimate $v_{e}$, the relative error variance during periods of no concurrent data at nearby stations. If the expected value is used to estimate discharge, the value that is used should be the expected value of discharge at the time of year of the missing record because of the seasonality of the streamflow processes. The variance of streamflow, which also is a seasonally varying parameter, is an estimate of the error variance that results from using the expected value as an estimate. Thus, the coefficient of variation, $C_{V}$, squared is an estimate of the required relative error variance $V_{e}$. Because $C_{V}$ varies seasonally and the times of failures cannot be anticipated, a seasonally averaged value of $C_{v}$ is used:

where

$$
\bar{c}_{v}=\left[\frac{1}{365} \sum_{i=1}^{365}\left(\frac{\sigma_{i}}{\mu_{i}}\right)^{2}\right]^{1 / 2}
$$

$$
\begin{aligned}
& \sigma_{i} \quad=\text { standard deviation of daily discharges for the } i^{\text {th }} \text { day of the } \\
& \text { year, } \\
& \mu_{i} \quad=\text { expected value of discharge on the } i^{\text {th }} \text { day of the year, and } \\
& \left(\bar{C}_{v}\right)^{2}=\text { used as an estimate of } v_{e} \text {. }
\end{aligned}
$$

The variance, $V_{r}$, of the relative error during periods of reconstructed streamflow records is estimated on the basis of correlation between records at the primary site and records from other nearby gaged sites. The 
correlation coefficient, $\rho_{C}$, between the streamflows with seasonal trends removed at the site of interest and detrended streamflows at the other sites is a measure of the goodness of their linear relationship. The fraction of the variance of streamflow at the primary site that is explained by data from the other sites is equal to $\rho^{2} \mathrm{c}$. Thus, the relative error variance of flow estimates at the primary site obtained from secondary information will be

$$
v_{r}=\left(1-\rho_{c}^{2}\right) \bar{c}_{v}^{2}
$$

Because errors in streamflow estimates arise from three different sources with widely varying precisions, the resultant distribution of those errors may differ significantly from a normal or log-normal distribution. This lack of normality causes difficulty in interpretation of the resulting average estimation variance. When primary and secondary data are unavailable, the relative error variance, $v_{e}$, may be very large. This could yield correspondingly large values of $\bar{V}$ in equation 4 even if the probability that primary and secondary information are not available, $\varepsilon_{e}$, is quite small.

A new parameter, the EGS (equivalent Gaussian spread), is introduced here to assist in interpreting the results of the analyses. If it is assumed that the various errors arising from the three situations represented in equation 4 are log-normally distributed, the value of EGS was determined by the probability statement that

$$
\text { Probability }\left[e^{-E G S} \leq\left(q_{C}(t) / q_{T}(t)\right) \leq e^{+E G S}\right]=0.683
$$

Thus, if the residuals $1 n q_{C}(t)-1 n q_{T}(t)$ were normally distributed, $(E G S)^{2}$ would be their variance. Here EGS is reported in units of percent because EGS is defined so that nearly two-thirds of the errors in instantaneousstreamflow data will be within plus or minus EGS percent of the reported values.

\section{The Application of Kalman-Filtering for Cost Effective Resource Allocation in Louisiana}

As a result of the first two parts of this analysis, it has been recommended that all 68 of the Louisiana District stream gages be continued in operation until the end of fiscal-year 1984. Of these 68 stations, 56 have a sufficient amount of data and are consistent with the K-CERA assumptions for this analysis. A complete K-CERA analysis has been performed on all of the data for 50 of these stations. The K-CERA analysis was performed on a part of the data for six stations. Of the remaining 12 stations on which K-CERA was not applied, five had insufficient data, and at seven, computational techniques inconsistent with the underlying assumptions were used. These 12 stations were carried through "The Traveling Hydrographer Program" with uncertainty functions assigned a value of zero, so that they would not influence the estimation of error. 


\section{Determination of Missing Record Probabilities}

As was described earlier, the statistical characteristics of missing stage or other correlative data for computation of streamflow records can be defined by a single parameter, the value of $k$ in the truncated negative exponential probability distribution of times to failure of the equipment. In the representation of $f(\tau)$ as given in equation 6 , the average time to failure is $1 / k$. The value of $1 / k$ varies from site to site with several factors influencing this variation. These factors include type of equipment, digital recorder punch interval, silting or sedimentation; frequency of visitation; and whether or not the site has supplemental record that can be used to recover gage-height record lost during periods of primary digital recorder failure.

The initial step in obtaining a value of $1 / k$ is the determination of the amount of gage record lost at each station for the existing conditions. Each of the 68 gaging stations was placed into one of three categories. The categories are:

1. Digital recorder, with no backup recorder;

2. Digital recorder, with supplemental gage record;

3. Special case stations, such as multi-gage slope stations, vandal-prone gages.

The amount of lost gage-height record was determined for the stations within each category that had record at anytime during water years 1975-82. The 1975-82 period was chosen because little change in technology or visit frequency occurred during those years. The average percent lost for each category was then computed and assigned to all the stations in the respective categories. The findings of the missing records analysis are summarized in table 7.

Table 7.--Results of missing record analysis for stream-gaging stations in Louisiana, water years 1975-82

\begin{tabular}{cccccc}
\hline Category & $\begin{array}{c}\text { Number of } \\
\text { stations } \\
\text { used in } \\
\text { the K-CERA } \\
\text { analysis }\end{array}$ & $\begin{array}{c}\text { Number of } \\
\text { stations } \\
\text { analyzed } \\
\text { for miss- } \\
\text { ing record }\end{array}$ & $\begin{array}{c}\text { Average } \\
\text { missing } \\
\text { record of } \\
\text { stations } \\
\text { analyzed } \\
\text { (percent) }\end{array}$ & $\begin{array}{c}\text { Maximum } \\
\text { missing } \\
\text { record at } \\
\text { individual } \\
\text { stations } \\
\text { (percent) }\end{array}$ & $\begin{array}{c}\text { Minimum } \\
\text { missing } \\
\text { individual } \\
\text { stations } \\
\text { (percent) }\end{array}$ \\
\hline 1 & 34 & 33 & 6 & 18 & 0 \\
2 & 11 & 11 & 5 & 9 & 0 \\
3 & 11 & 10 & 14 & 31 & 7 \\
\hline
\end{tabular}

The estimates of lost record and visit frequency for each station were used to determine $1 / k$ and, subsequently, $\varepsilon_{f}, \varepsilon e$, and $\varepsilon r$ for each station. 


\section{Determination of Coefficient of Variation and Cross-Correlation Coefficient}

To compute the values of $V_{e}$ and $V_{r}$ of the needed uncertainty functions, estimates of $C_{v}$ (the coefficient of variation) and $\rho_{C}$ (the crosscorrelation coefficient) were needed for each station. All of the daily streamflow data available for the last 30 years (1953-82) at each station were retrieved from WATSTORE (Hutchinson, 1975). Using these data, a value of $C_{V}$ and $\rho_{C}$ was computed for 53 of the 56 stations used in the K-CERA analysis.

A maximum, oc, was obtained for each of these stations by investigating various combinations of station correlations with several options regarding lag time in days. A second $\rho_{C}$ was obtained where more than one station or combination of stations correlated. For the remaining three stations, which had insufficient amounts or improper types of data, $C_{v}$ and $\rho_{C}$ were estimated based on computed values for stations with similar hydrologic characteristics.

On the average, each station was visited 10 times per year for the period 1953-82. The 10 visit average was used in the traveling-hydrographer model, along with the values of $C_{V}$ and maximum $\rho_{C}$ computed for each station.

Values of the percentage of time that record is lost, of $C_{v}$, and of $\rho_{C}$, and sources of record reconstruction are shown in table 8 . The maximum and minimum, $C_{v}$, values are 239.0 percent for station 07352800 and 51.6 percent for station 07385500 , respectively. Likewise, the maximum and minimum values of $\rho c$ are 0.933 for station 08015500 and 0.193 for stations 07349860 and 07386700 , respectively. These extremes are consistent with what is intuitively known about the Louisiana stations.

\section{Kalman-Filtering Determination of Variance}

The determination of the variance $V_{f}$ for each stream gage included in the uncertainty-function analysis required the execution of three distinct steps: (1) long-term stage versus discharge rating analysis and computation of residuals of measured discharges from the long-term rating, (2) time-series analysis of the residual to determine the input parameters of the Kalman-filter streamflow records, and (3) computation of the error variance, $V_{f}$, as a function of the time-series parameters, the dischargemeasurement-error variance, and the frequency of discharge measurement.

Long-term rating analysis of stream-gaging stations in Louisiana began with the identification of a representative period for which each station should be analyzed. In general, an attempt was made to use discharge measurements made within the last 10 years (1973-82). The majority of the sites were analyzed using 40 to 100 individual measurements. Stations with relatively short periods of record (3-6 years) had fewer measurements that could be included in the analysis. Several stations where a definite rating change accompanied the occurrence of a major event, such as a flood, channel dredging, or the construction of a 
Table 8.--Statistics used in reconstructing records for Louisiana stream gages

$\left[C_{V}\right.$, coefficient of variation; $\rho_{C}$, cross-correlation coefficient $]$

\begin{tabular}{|c|c|c|c|c|}
\hline $\begin{array}{l}\text { Station } \\
\text { number }\end{array}$ & $\begin{array}{l}\text { Average } \\
\text { missing } \\
\text { stage } \\
\text { record } \\
\text { (percent) }\end{array}$ & $c_{v}$ & ${ }^{\circ} \mathrm{C}$ & $\begin{array}{c}\text { Source of } \\
\text { reconstructed } \\
\text { records } \\
(1 \text { ag in days } \\
\text { for maximum oc) }\end{array}$ \\
\hline 02489500 & 5 & 91.5 & 0.683 & 02492000 \\
\hline 02490105 & 6 & 112.3 & .727 & 07375000 (0) \\
\hline 02492000 & 6 & 105.8 & .706 & 07375000 (0) \\
\hline 07344400 & 6 & 95.4 & .511 & $07348700 \quad(0)$ \\
\hline 07344450 & 6 & 238.6 & .551 & 07349795 (0) \\
\hline 07348000 & 5 & 162.5 & .565 & 07344400 \\
\hline 07348700 & 6 & 205.6 & .807 & 07349500 \\
\hline 07349500 & 6 & 198.4 & .807 & $07348700 \quad(0)$ \\
\hline 07349795 & 6 & 198.4 & .807 & $07348700 \quad(0)$ \\
\hline 07349860 & 6 & 102.8 & .193 & 07349374 (0) \\
\hline 07351500 & 6 & 139.7 & .514 & 07344450 \\
\hline 07351600 & 6 & 127.1 & .747 & $08023400 \quad(0)$ \\
\hline 07351750 & 14 & 127.1 & .747 & $\begin{array}{l}C_{V} \text { and } \rho_{C} \text { estimated } \\
\text { from } 07351600\end{array}$ \\
\hline 07352000 & 6 & 162.2 & .752 & $07352800(0)$ \\
\hline 07352800 & 6 & $239: 0$ & .752 & $07352000 \quad(0)$ \\
\hline 07354100 & 6 & 217.1 & .688 & $\begin{array}{l}C_{v_{v}} \text { and } \rho_{C} \text { estimated } \\
\text { from } 08025500\end{array}$ \\
\hline 07364100 & 5 & 116.8 & .788 & $\begin{array}{l}C_{v_{v}} \text { and } \rho_{C} \text { estimated } \\
\text { from } 07367630\end{array}$ \\
\hline 07364200 & 14 & 116.8 & .788 & $07369700 \quad(0)$ \\
\hline 07366200 & 6 & 187.8 & .682 & 07348700 \\
\hline 07368000 & 14 & 133.2 & .737 & 07369000 \\
\hline 07369500 & 14 & 186.6 & .737 & 07370000 \\
\hline 07369700 & 6 & 131.6 & .895 & $07370000 \quad(1)$ \\
\hline 07370000 & 14 & 146.3 & .783 & $07369700(-1)$ \\
\hline 07371500 & 6 & 162.2 & .662 & $07352000(0)$ \\
\hline 07372200 & 14 & 188.0 & .554 & $07371500(-1)$ \\
\hline 07373000 & 6 & 159.0 & .559 & $07373250 \quad(0)$ \\
\hline 07373250 & 6 & 159.0 & .559 & 07373000 \\
\hline 07375000 & 6 & 149.7 & .846 & 07375500 \\
\hline 07375500 & 6 & 123.4 & .854 & 07376000 \\
\hline 07376000 & 5 & 142.8 & .854 & 07375500 \\
\hline 07376500 & 6 & 219.2 & .719 & 07375500 \\
\hline 07377000 & 5 & 146.3 & .783 & 07377500 \\
\hline 07377240 & 6 & 178.3 & .668 & 07377782 \\
\hline 07377500 & 5 & 182.5 & .783 & 07377000 \\
\hline 07377782 & 6 & 203.4 & .721 & 07377782 \\
\hline 07378000 & 6 & 199.7 & .815 & $07378500 \quad(0)$ \\
\hline 07378500 & 5 & 145.8 & .921 & $07377000(-2)$ \\
\hline & & & & $07378000 \quad(0)$ \\
\hline
\end{tabular}


Table 8.--Statistics used in reconstructing records for Louisiana stream gages--Continued

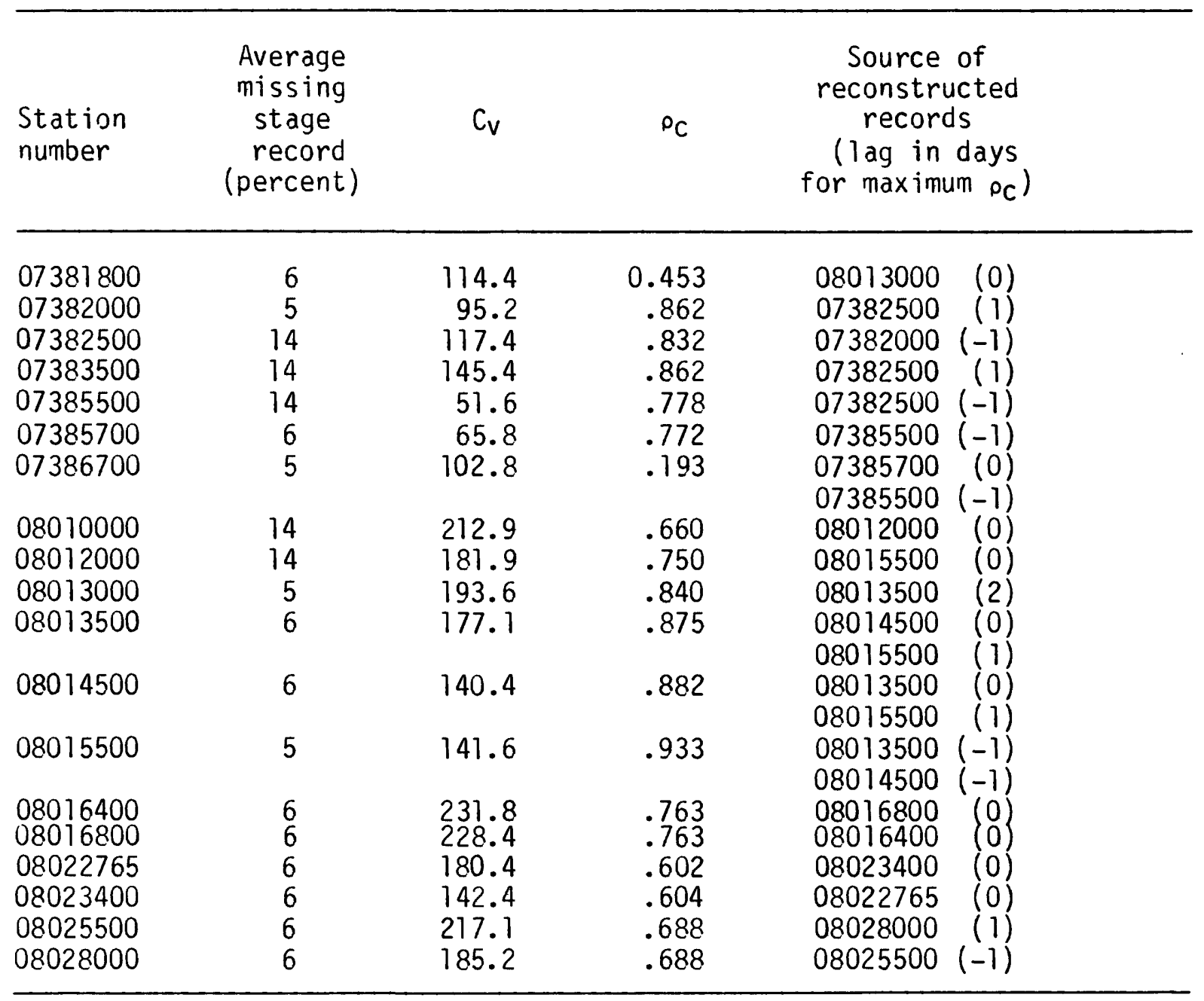

new bridge, were analyzed using measurements made subsequent to this event and prior to the occurrence of another significant event.

Following the selection of a representative series of discharge measurements for each station, the next step was to define the rating curve and compute the time series of residuals that represent the difference between the rating curve and the measured discharges. Rating curves were constructed on logarithmic paper by plotting the previously selected measurements and fitting a curve through these points using the current rating curve as a guide for scale offset and for checking significant rating changes.

Ratings were computed using a logarithmic curve-fitting procedure on the Survey computer in Reston, Va., for stations at which non-uniformities in the control or channel cross section do not distort the shape of the rating curve. The rating function in the procedure:

$$
L Q M=B 1+B 3[L O G(G H T-B 2)]
$$


in which

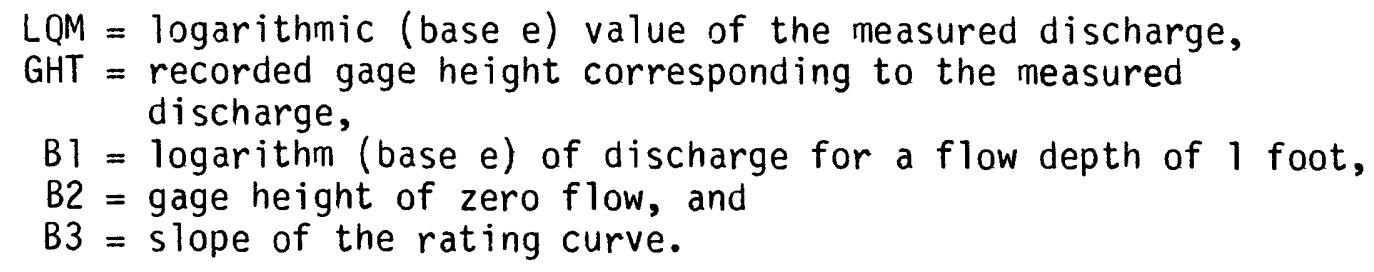

For those stations where the computerized curve-fitting procedure did not adequately describe the rating, an alternate curve-fitting technique was used. For the selected measurements, stage and discharge were plotted on logarithmic paper, using the same scale offset as the currently used rating. A best-fit curve was drawn through these points. The shape was compared to the currently used rating and adjusted where necessary. Enough rating coordinates were chosen to describe a rating table computed by logarithmic linear interpolation. Residuals were then computed and analyzed to insure that the rating drawn was satisfactory.

Stations affected by variable backwater or changing discharge were analyzed using one of the above methods, but the discharge adjusted for variable backwater was used in place of the actual measured discharge. Using the adjusted discharge was necessary to compute residuals that were more representative of the scatter about the rating curves.

After the ratings were prepared, residuals were analyzed with respect to time and gage height to ensure that the selected measurements represent a stable period of time during which no physical changes were occurring in the stream channel. The residuals for six gaging stations indicated that the channels were not stable for lower gage heights. A large scatter at the lower end of the rating, as shown in a plot of residuals versus the log of gage height for station 07348700 (fig. 9), is typical of the six stations. The instability of the ratings at lower discharges is due to construction of beaver dams and trash buildup with subsequent washout. For these six stations, only the upper part of the stage-discharge relationship was used to determine the variance so that the accuracy of the record would not be inappropriately distorted. The percentage of the record used for each of the six stations is shown in table 9. The station uncertainty functions were weighted accordingly for subsequent analyses.

Table 9.--Stations for which only the upper part of the stage-discharge relationship was used for the determination of variance

\begin{tabular}{cc}
\hline Station number & Percent of record used \\
\hline 07348700 & 75 \\
07370000 & 53 \\
07376500 & 30 \\
07377240 & 25 \\
07377782 & 63 \\
08016800 & 78 \\
\hline
\end{tabular}




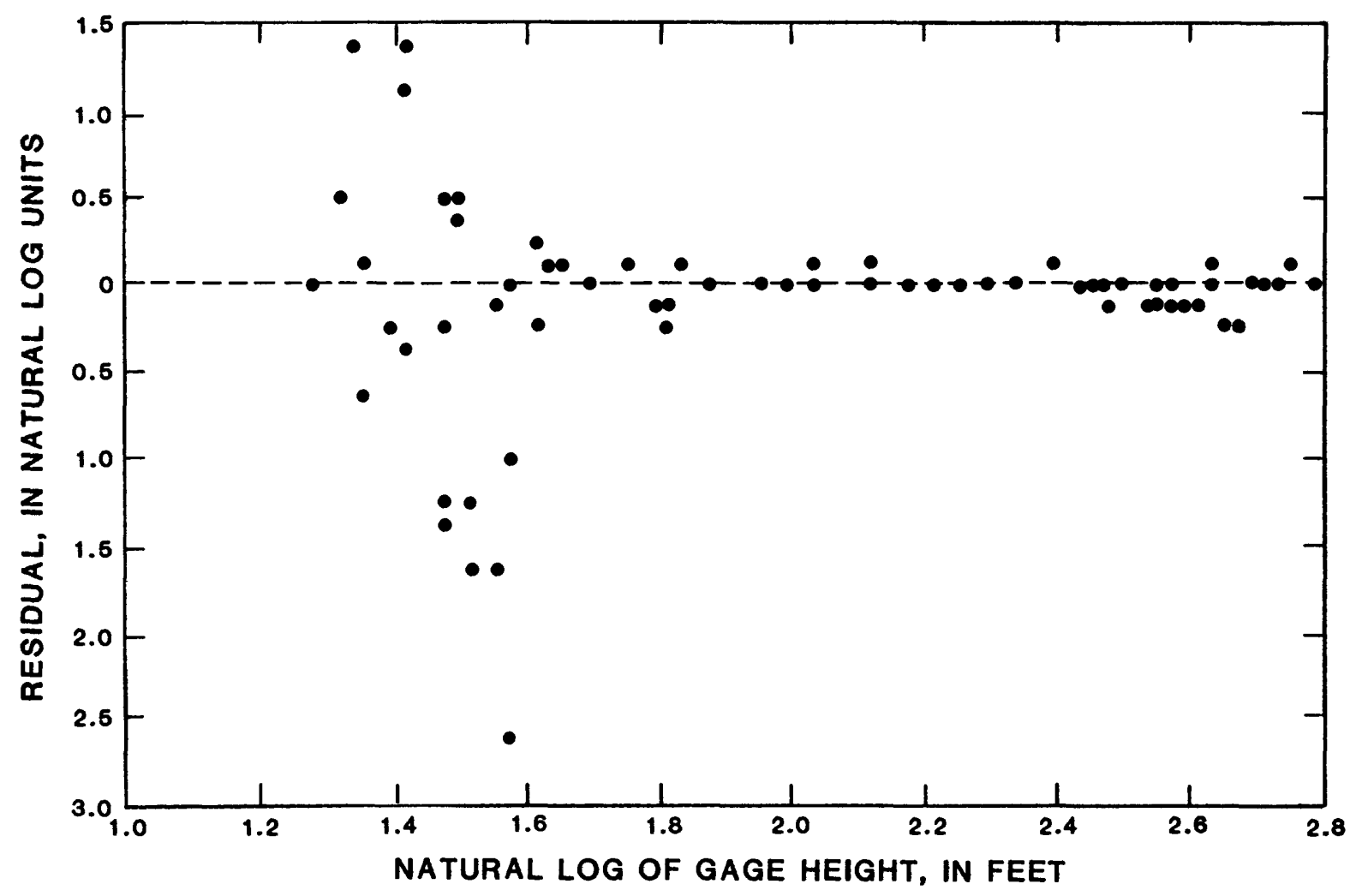

Figure 9.--Residual versus natural $\log$ of gage height for station 07348700, Bayou Dorcheat near Springhil1, Louisiana.

Ruth Canal at Ruth, La., (07386700) is affected by multiple gate openings, and discharge is computed from several different ratings, depending upon the combination and magnitude of gate openings and head. For this station, residuals were determined by computing the difference between the measured discharge and the discharge from the appropriate rating.

Tabular presentations of residuals of the measured discharges about the rating curve of two gaging stations, which are representative of streams in Louisiana, are given in tables 10 and 11. Bayou Pierre near Lake End (07351750) represents a station affected by variable backwater and Dugdemona River near Jonesboro (07371500) represents a station with a normal stage-discharge relationship. The time series of residuals is used to compute sample estimates of $q$ and $B$, two of the three parameters required to compute $V_{f}$, by determining a best fit autocovariance function to the time series of residuals. Measurement variance, the third parameter, is determined from an assumed constant percentage standard error. Measurement error in Louisiana is approximately 5 percent, on the average, for all stations.

As discussed earlier, $q$ and $\beta$ can be expressed as the process variance of the shifts from the rating curve and the 1-day autocorrelation coefficient of these shifts. Table 12 presents a summary of the autocovariance analysis expressed in terms of process variance and 1-day autocorrelation. 
Table 10.---Residual data for Bayou Pierre near Lake End, Louisiana

\begin{tabular}{|c|c|c|c|c|c|c|c|}
\hline \multirow[t]{2}{*}{$\begin{array}{l}\text { Obser- } \\
\text { vation } \\
\text { number }\end{array}$} & \multirow[t]{2}{*}{ Date } & \multirow[t]{2}{*}{$\begin{array}{c}\text { Lag } \\
\text { (days) }\end{array}$} & $\begin{array}{l}\text { Measured } \\
\text { discharge }\end{array}$ & $\begin{array}{l}\text { Slope } \\
\text { adjusted } \\
\text { discharge }\end{array}$ & $\begin{array}{l}\text { Predicted } \\
\text { discharge }\end{array}$ & Residual & \multirow[t]{2}{*}{$\begin{array}{c}\text { Percent } \\
\text { error }\end{array}$} \\
\hline & & & \multicolumn{4}{|c|}{ cubic feet per second } & \\
\hline $\begin{array}{r}6 \\
7 \\
8 \\
9 \\
10 \\
11 \\
12 \\
13 \\
14 \\
15 \\
16 \\
17 \\
18 \\
20 \\
21 \\
22 \\
23 \\
24 \\
27 \\
28 \\
29 \\
30 \\
31 \\
32 \\
33 \\
34 \\
35 \\
36 \\
37\end{array}$ & $\begin{array}{r}6-3-80 \\
7-7-80 \\
8-29-80 \\
9-24-80 \\
10-29-80 \\
12-12-80 \\
1-26-81 \\
3-12-81 \\
4-14-81 \\
6-3-81 \\
7-9-81 \\
8-26-81 \\
10-2-81 \\
11-17-81 \\
12-15-81 \\
1-25-82 \\
3-8-82 \\
4-22-82 \\
8-23-82 \\
10-6-82 \\
11-22-82 \\
12-15-82 \\
1-3-83 \\
1-24-83 \\
2-22-83 \\
4-19-83 \\
5-2-83 \\
5-31-83 \\
7-5-83\end{array}$ & $\begin{array}{r}-- \\
34 \\
53 \\
26 \\
35 \\
44 \\
45 \\
45 \\
33 \\
50 \\
36 \\
48 \\
37 \\
46 \\
28 \\
41 \\
42 \\
45 \\
123 \\
44 \\
47 \\
23 \\
19 \\
21 \\
29 \\
56 \\
13 \\
29 \\
35\end{array}$ & $\begin{array}{r}372.0 \\
56.6 \\
36.8 \\
35.4 \\
48.2 \\
51.2 \\
59.3 \\
204.0 \\
57.9 \\
442.0 \\
125.0 \\
26.0 \\
49.3 \\
220.0 \\
44.1 \\
249.0 \\
368.0 \\
4,020.0 \\
41.3 \\
20.9 \\
374.0 \\
3,860.0 \\
4,060.0 \\
302.0 \\
4,350.0 \\
152.0 \\
130.0 \\
1,510.0 \\
201.0\end{array}$ & $\begin{array}{r}372.0 \\
56.6 \\
36.8 \\
35.4 \\
48.2 \\
51.2 \\
59.3 \\
354.0 \\
57.9 \\
667.0 \\
546.0 \\
26.0 \\
49.3 \\
791.0 \\
44.1 \\
249.0 \\
423.0 \\
4,020.0 \\
41.3 \\
20.9 \\
374.0 \\
5,330.0 \\
5,530.0 \\
304.0 \\
4,350.0 \\
152.0 \\
130.0 \\
1,850.0 \\
568.0\end{array}$ & $\begin{array}{r}428.2 \\
56.5 \\
42.0 \\
51.9 \\
58.5 \\
65.6 \\
74.0 \\
299.2 \\
50.7 \\
578.6 \\
413.5 \\
30.6 \\
45.7 \\
721.8 \\
42.0 \\
231.6 \\
395.0 \\
4,294.4 \\
33.5 \\
21.3 \\
341.3 \\
5,317.1 \\
5,480.6 \\
285.7 \\
4,122.9 \\
137.0 \\
99.9 \\
1,837.6 \\
498.6\end{array}$ & $\begin{array}{r}-56.2 \\
.1 \\
-5.2 \\
-16.5 \\
-10.3 \\
-14.4 \\
-14.7 \\
-54.8 \\
7.2 \\
-88.4 \\
-132.5 \\
-4.6 \\
3.6 \\
-69.2 \\
2.1 \\
17.4 \\
-28.0 \\
-274.4 \\
7.9 \\
-.4 \\
32.7 \\
-12.9 \\
-212.9 \\
18.3 \\
227.1 \\
15.0 \\
30.1 \\
-12.4 \\
-69.4\end{array}$ & $\begin{array}{r}-13.1 \\
-12.4 \\
-31.8 \\
-17.6 \\
-22.0 \\
-19.9 \\
-18.3 \\
14.2 \\
-15.3 \\
-32.0 \\
-15.0 \\
7.9 \\
-9.6 \\
5.0 \\
7.5 \\
-7.1 \\
-6.3 \\
23.6 \\
-1.9 \\
9.6 \\
-.2 \\
-3.9 \\
6.4 \\
5.5 \\
10.9 \\
30.1 \\
-.7 \\
-13.9\end{array}$ \\
\hline
\end{tabular}

The autocovariance parameters, summarized in table 12, and data from the definition of missing record probabilities, summarized in table 8 , are used jointly to define uncertainty functions for each of the 56 gaging stations analyzed. The uncertainty functions give the relationship of total variance to the number of visits and discharge measurements. The stations for which residual data were previously given are typical examples and their uncertainty functions are shown in figure 10. These functions are based on the assumption that a discharge measurement is made during each visit to the station. 
Table 11.--Residual data for Dugdemona River near Jonesboro, Louisiana

\begin{tabular}{|c|c|c|c|c|c|c|}
\hline \multirow{2}{*}{$\begin{array}{l}\text { Obser- } \\
\text { vation } \\
\text { number }\end{array}$} & \multirow[t]{2}{*}{ Date } & \multirow[t]{2}{*}{$\begin{array}{l}\text { Lag } \\
\text { (days) }\end{array}$} & $\begin{array}{l}\text { Measured } \\
\text { discharge }\end{array}$ & $\begin{array}{l}\text { Predicted } \\
\text { discharge }\end{array}$ & Residual & \multirow[t]{2}{*}{$\begin{array}{l}\text { Percent } \\
\text { error }\end{array}$} \\
\hline & & & \multicolumn{3}{|c|}{ cubic feet per second } & \\
\hline 323 & $9-26-77$ & -- & 21.2 & 17.5 & 3.7 & -21.1 \\
\hline 324 & $10-28-77$ & 32 & 22.6 & 17.5 & 5.3 & 30.3 \\
\hline 325 & $11-23-77$ & 26 & 26.5 & 27.8 & -1.3 & -4.7 \\
\hline 326 & $12-20-77$ & 27 & 58.8 & 59.2 & -.4 & -.7 \\
\hline 327 & $1-26-78$ & 37 & 715.0 & 744.1 & -29.1 & -3.9 \\
\hline 328 & $3-8-78$ & 41 & 158.0 & 136.1 & 21.9 & 16.1 \\
\hline 329 & $3-9-78$ & 1 & 187.0 & 165.4 & 21.6 & -13.1 \\
\hline 330 & $4-7-78$ & 29 & 62.4 & 63.8 & -1.4 & -2.2 \\
\hline 331 & $5-8-78$ & 31 & $6,490.0$ & $6,703.0$ & -213.0 & -3.2 \\
\hline 332 & $5-11-78$ & 3 & $4,000.0$ & $3,920.0$ & 80.0 & 2.0 \\
\hline 333 & $5-12-78$ & 1 & $2,680.0$ & $2,706.5$ & -26.5 & -1.0 \\
\hline 334 & $5-16-78$ & 4 & 809.0 & 840.6 & -31.6 & -3.8 \\
\hline 335 & $5-19-78$ & 3 & 233.0 & 235.3 & -2.3 & -1.0 \\
\hline 336 & $5-22-78$ & 3 & 104.0 & 102.0 & 2.0 & 2.0 \\
\hline 337 & $5-22-78$ & 0 & 95.3 & 98.2 & -2.9 & -3.0 \\
\hline 338 & $5-24-78$ & 2 & 86.3 & 79.8 & 6.5 & 8.1 \\
\hline 339 & $6-12-78$ & 19 & 39.7 & 31.9 & 7.8 & 24.5 \\
\hline 340 & $6-13-78$ & 1 & 29.2 & 30.6 & -1.4 & -4.6 \\
\hline 341 & $6-15-78$ & 2 & 23.5 & 21.9 & 1.6 & 7.3 \\
\hline 342 & $6-18-78$ & 3 & 20.9 & 20.0 & .9 & 4.5 \\
\hline 343 & $6-26-78$ & 8 & 18.1 & 17.5 & .6 & 3.4 \\
\hline 344 & $7-14-78$ & 18 & 16.2 & 16.3 & -.1 & -.6 \\
\hline 345 & $7-24-78$ & 10 & 7.8 & 9.3 & -1.5 & 16.1 \\
\hline 346 & $9-19-78$ & 57 & 41.7 & 37.3 & 4.4 & 11.8 \\
\hline 347 & $11-20-78$ & 62 & 21.7 & 25.7 & -4.0 & -15.6 \\
\hline 348 & $1-22-79$ & 63 & $8,290.0$ & $6,948.0$ & $1,342.0$ & 19.3 \\
\hline 349 & $3-12-79$ & 49 & 885.0 & 984.0 & -99.0 & -10.1 \\
\hline 350 & $4-3-79$ & 22 & $5,940.0$ & $5,744.0$ & 196.0 & 3.4 \\
\hline 351 & $4-26-79$ & 23 & $2,560.0$ & $2,418.0$ & 142.0 & 5.9 \\
\hline 352 & $6-14-79$ & 49 & 46.9 & 48.7 & -1.8 & -3.7 \\
\hline 353 & $7-9-79$ & 25 & 18.2 & 18.8 & -0.6 & -3.3 \\
\hline 354 & $8-14-79$ & 36 & 18.2 & 18.4 & 0.2 & 1.1 \\
\hline 355 & $10-3-79$ & 50 & 26.8 & 22.7 & 4.1 & 18.1 \\
\hline 356 & $11-8-79$ & 36 & 22.3 & 21.7 & 0.6 & 2.8 \\
\hline 357 & $1-7-80$ & 60 & 197.0 & 195.0 & 2.0 & 1.0 \\
\hline 358 & $2-21-80$ & 45 & 272.0 & 271.0 & 1.0 & .4 \\
\hline 359 & $3-31-80$ & 39 & $3,660.0$ & $3,494.0$ & 166.0 & 4.8 \\
\hline 360 & $5-13-80$ & 43 & 87.7 & 86.5 & 1.2 & 1.4 \\
\hline 361 & $6-23-80$ & 41 & 71.2 & 52.0 & 19.2 & 36.9 \\
\hline 362 & $6-30-80$ & 7 & 33.5 & 25.7 & 7.8 & 30.4 \\
\hline 363 & $7-28-80$ & 28 & 17.6 & 14.4 & 3.2 & 22.2 \\
\hline 364 & $8-6-80$ & 9 & 13.7 & 12.6 & 1.1 & 8.7 \\
\hline 365 & $8-6-80$ & 0 & 14.3 & 12.6 & 1.7 & 13.5 \\
\hline 366 & $9-2-80$ & 27 & 15.4 & 14.8 & .6 & 4.1 \\
\hline
\end{tabular}


Table 11.--Residual data for Dugdemona River near Jonesboro, Louisiana--Continued

\begin{tabular}{lccccrr}
\hline $\begin{array}{l}\text { Obser- } \\
\text { vation } \\
\text { number }\end{array}$ & Date & $\begin{array}{c}\text { Lag } \\
\text { (days) }\end{array}$ & $\begin{array}{l}\text { Measured } \\
\text { discharge }\end{array}$ & $\begin{array}{l}\text { Predicted } \\
\text { discharge }\end{array}$ & Residual & $\begin{array}{r}\text { Percent } \\
\text { error }\end{array}$ \\
\cline { 3 - 5 } & & & \multicolumn{2}{c}{ cubic feet per second } & \\
\hline 367 & $10-1-80$ & 29 & 21.9 & 19.1 & 1.9 & 10.0 \\
368 & $11-3-80$ & 33 & 31.1 & 26.6 & 4.5 & 16.9 \\
369 & $12-5-80$ & 32 & 22.8 & 29.0 & -6.2 & -21.4 \\
370 & $1-19-81$ & 45 & 23.1 & 25.7 & -2.6 & -10.1 \\
371 & $3-5-81$ & 45 & 434.0 & 419.6 & 14.4 & 3.4 \\
372 & $4-22-81$ & 48 & 52.6 & 51.0 & 1.6 & 3.1 \\
374 & $5-27-81$ & 35 & 44.3 & 45.9 & -1.6 & -3.5 \\
375 & $7-10-81$ & 44 & 18.1 & 18.0 & .1 & .6 \\
376 & $8-26-81$ & 47 & 22.1 & 20.0 & 2.1 & 10.5 \\
377 & $9-29-81$ & 34 & 17.3 & 18.0 & -.7 & -3.9 \\
\hline
\end{tabular}

\section{Determination of Routes}

The stream-gaging program in Louisiana is currently conducted from offices in Alexandria, Baton Rouge, Lake Charles, and Ruston. The Alexandria office routinely services 18 streamflow gaging stations, the Baton Rouge office services 16, the Lake Charles office services 13, and the Ruston office services 21 gages. Duties of each office have been structured to existing personnel and the work-load distributed with regard not only to continuous-record-station operation but also to operation of ground-water level sites, flood-profile stations, stage stations, and crest-stage stations. As the operation of continuous-record stations represents only a part of each office's responsibilities, no attempt was made to redistribute the gaging stations among the four offices. Instead, the "Traveling Hydrographer Program" was applied to the stream-gaging activities of all offices simultaneously.

Routes currently used to service streamflow gaging stations as well as stations operated for other purposes were defined by field office personnel. Alternate routes including visits to key individual stations or combinations grouping gages based on proximity and (or) the estimated frequency of visitation indicated by the uncertainty function analysis were then determined for each office. There were a total of 93 feasible routes for all offices, with 27 for Alexandria, 22 for Baton Rouge, 20 for Lake Charles, and 24 for Ruston. These routes and the stations visited on each route are summarized in table 13.

The costs associated with each of the 93 routes consisted of three components: fixed costs, visit costs, and route costs. Fixed costs to operate a gage typically include equipment rental, batteries, data processing and storage, computer charges, maintenance and miscellaneous supplies, and analysis and supervisory charges. Visit costs are those 
Table 12.--Summary of the autocovariance analysis of the Louisiana stream-gaging network

\begin{tabular}{llccc}
\hline $\begin{array}{l}\text { Station } \\
\text { number }\end{array}$ & $\begin{array}{c}\text { RHO, } \text { a , (one-day } \\
\text { autocorrelation } \\
\text { coefficient })\end{array}$ & $\begin{array}{c}\text { Process } \\
\text { variance } \\
\left(\log \text { base } e^{2}\right)\end{array}$ & $\begin{array}{c}\text { Measurement } \\
\text { variance }\end{array}$ & $\begin{array}{c}\text { Number of } \\
\text { measurements } \\
\text { analyzed }\end{array}$ \\
\hline
\end{tabular}

$\begin{array}{ll}02489500 & 0.963 \\ 02490105 & .971 \\ 02492000 & .990 \\ 07344400 & .966 \\ 07344450 & .992 \\ 07348000 & .900 \\ 07348700 & .971 \\ 07349500 & .973 \\ 07349795 & .977 \\ 07349860 & .945 \\ 07351500 & .980 \\ 07351600 & .949 \\ 07351750 & .981 \\ 07352000 & .958 \\ 07352800 & .913 \\ 07354100 & .718 \\ 07364100 & .988 \\ 07364200 & .989 \\ 07366200 & .977 \\ 07368000 & .954 \\ 07369500 & .988 \\ 07369700 & .987 \\ 07370000 & .973 \\ 07371500 & .951 \\ 07372200 & .579 \\ 07373000 & .966 \\ 07373250 & .976 \\ 07375000 & .949 \\ 07375500 & .973 \\ 07376000 & .984 \\ 07376500 & .993 \\ 07377000 & .997 \\ 07377240 & .094 \\ 07377500 & .982 \\ 07377782 & .957 \\ 07378000 & .992 \\ 07378500 & .986 \\ 07381800 & .956 \\ 07382000 & .985 \\ 07382500 & .610 \\ 07383500 & .989 \\ 07385500 & .969 \\ 07385700 & .883 \\ 07386700 & .985 \\ 08010000 & .972 \\ & \end{array}$

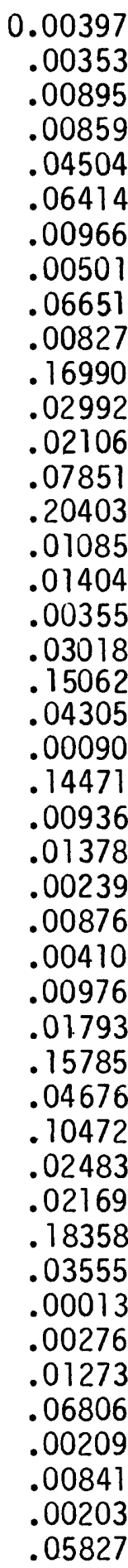

0.0025

.0025

.0025

.0025

.0025

.0025

.0025

.0025

.0025

.0025

.0025

.0025

.0025

.0025

.0025

.0025

.0025

.0025

.0025

.0025

.0025

.0025

.0025

.0025

.0025

.0025

.0025

.0025

.0025

.0025

.0025

.0025

.0025

.0025

.0025

.0025

.0025

.0025

.0025

.0025

.0025

.0025

.0025

.0025

.0025
73

105

60

24

50

24

71

74

71

39

51

47

54

65

74

22

32

63

41

82

62

67

59

54

78

73

48

113

73

102

70

59

62

54

68

24

61

71

70

67

67

60

52

26

77 
Table 12.--Summary of the autocovariance analysis of the Louisiana stream-gaging network--Continued

\begin{tabular}{lcccc}
\hline $\begin{array}{l}\text { Station } \\
\text { number }\end{array}$ & $\begin{array}{c}\text { RHO, o, (one-day } \\
\text { autocorrelation } \\
\text { coefficient) }\end{array}$ & $\begin{array}{c}\text { Process } \\
\text { variance } \\
\left.\text { (log base } e^{2}\right)\end{array}$ & $\begin{array}{c}\text { Measurement } \\
\text { variance }\end{array}$ & $\begin{array}{c}\text { Number of } \\
\text { measurements } \\
\text { analyzed }\end{array}$ \\
\hline 08012000 & 0.926 & 0.12589 & 0.0025 & 62 \\
08013000 & .955 & .00316 & .0025 & 93 \\
08013500 & .982 & .00598 & .0025 & 71 \\
08014500 & .982 & .00478 & .0025 & 75 \\
08015500 & .973 & .02196 & .0025 & 70 \\
08016400 & .964 & .05849 & .0025 & 70 \\
08016800 & .947 & .02288 & .0025 & 61 \\
08022765 & .981 & .12218 & .0025 & 52 \\
08023400 & .952 & .06787 & .0025 & 28 \\
08025500 & .965 & .01627 & .0025 & 77 \\
08028000 & .988 & .02299 & .0025 & 69 \\
\hline
\end{tabular}

associated with paying the hydrographer for the time actually spent at a station servicing the equipment and making a discharge measurement. Route costs include the vehicle cost associated with driving the number of miles it takes to cover the route, the cost of the hydrographer's time while in transit, and any per diem associated with the time it takes to complete the trip.

Visit and route costs were determined by calculating the distance and time spent on each route and the time required to service each station. These times and distances were multiplied by the average hourly salary and average vehicle mileage charge for the appropriate field office. Fixed costs were determined by subtracting the visit and route costs from the total cost of operating each gage.

\section{Kalman-Filtering for Cost Effective Resource Allocation Results}

The "Traveling Hydrographer Program" utilizes the uncertainty functions along with the appropriate cost data and route definitions to compute the most cost-effective way of operating the stream-gaging program. In this application, the first step was to simulate the current practice and determine the total uncertainty associated with it. To accomplish this, the number of visits being made to each stream gage and the specific routes that are being used to make these visits were fixed and the associated uncertainty was computed. The resulting average error of estimation for the current practice in Louisiana, 34.6 percent, is plotted as a point in figure 11 corresponding to the current operational budget of $\$ 423,000$.

The solid line in figure 11 represents the minimum level of average uncertainty that can be obtained for a given budget with the existing instrumentation and technology. The line was defined by applying the "Traveling Hydrographer Program" several times using a different budget for each application. 


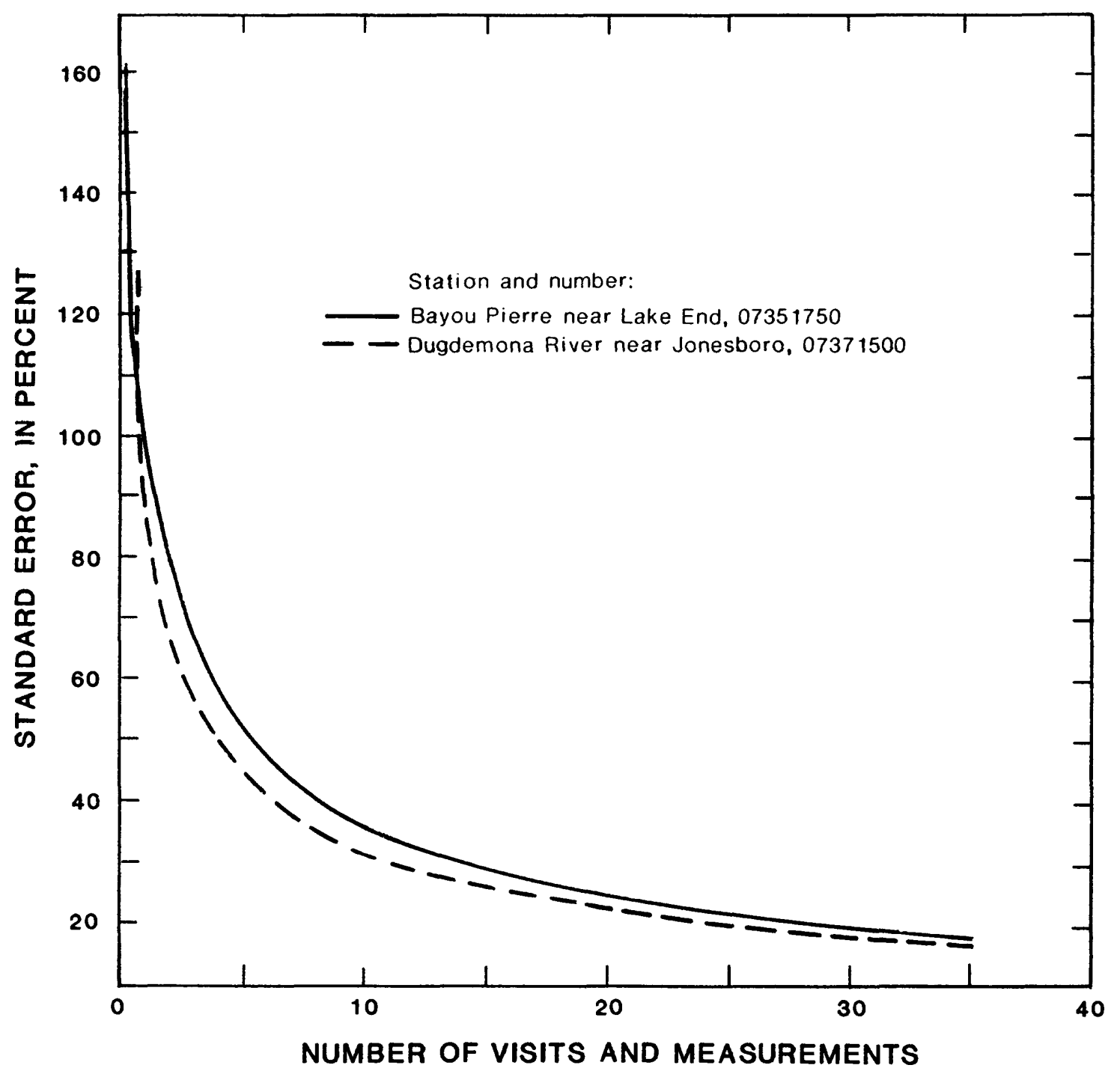

Figure 10.--Typical uncertainty functions for instantaneous discharges at two Louisiana stations.

Another operational constraint is the minimum allowable stationvisitation frequency. To determine the minimum number of times each station must be visited, consideration was given to the physical limitations of the data-collection method and the limitations of the previously made K-CERA assumptions. For most stations, the minimum visit frequency was set at four. Most stations affected by variable backwater must be visited at least six times, and some stations are visited a minimum of 8 , 12 , or 26 times, depending upon use of the data.

The results of the K-CERA analysis are summarized in table 14 and figure 11. These results are predicated on a discharge measurement being made upon each visit to a gaging station. A minimum budget of $\$ 400,000$ is required to operate the 68 gages and results in an average standard error of estimate of 39.6 percent. The current policy requires a budget of 
Table 13.--Summary of routes that may be used to visit stream-gaging stations in Louisiana

[The routes do not include the noncontinuous-record gaging stations being serviced on each route]

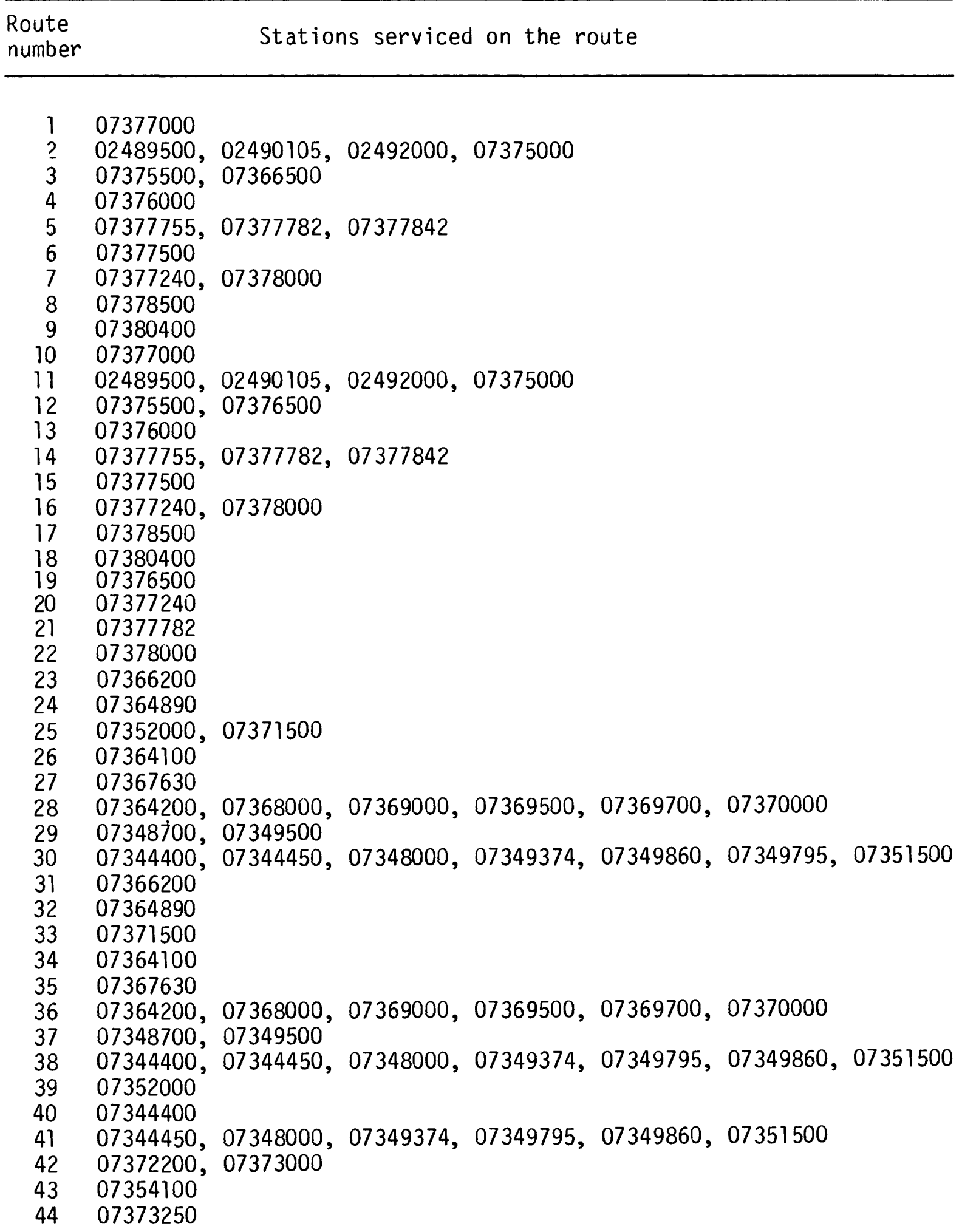


Table 13.--Summary of routes that may be used to visit stream-gaging stations in Louisiana--Continued

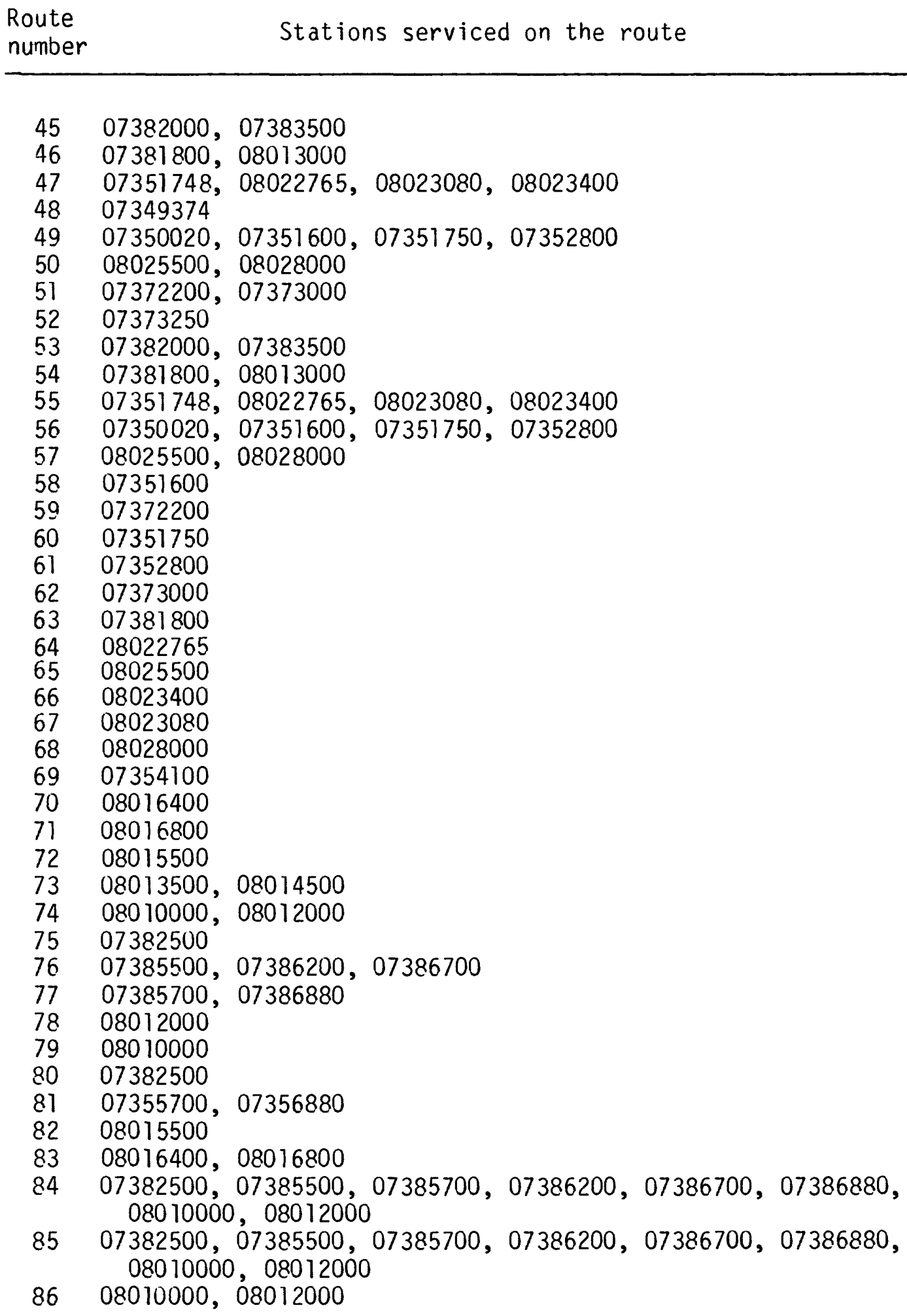


Table 13.-- Summary of routes that may be used to visit stream-gaging stations in Louisiana--Continued

\begin{tabular}{ll}
\hline $\begin{array}{l}\text { Route } \\
\text { number }\end{array}$ & Stations serviced on the route \\
\hline 87 & 08010000 \\
88 & 07382500 \\
89 & 07368000,07370000 \\
90 & 07370000 \\
91 & 08013500 \\
92 & 07369000 \\
93 & 07367630 \\
\hline
\end{tabular}

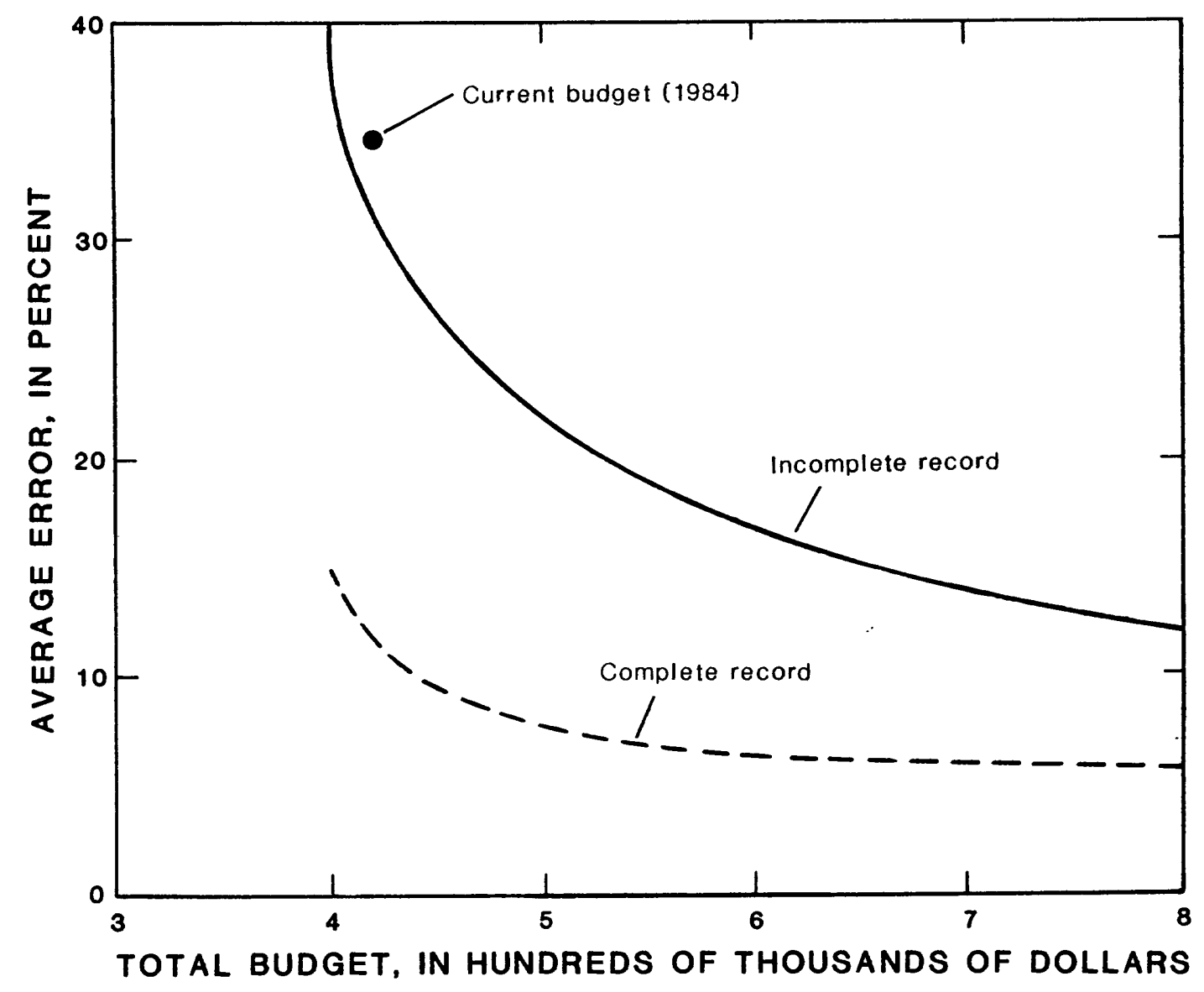

Figure 11.--Average error or estimate versus operational budget for Louisiana. 
Table 14.--Selected results of Kalman-Filtering for Cost-Effective Resource Allocation analysis of Louisiana stream-gaging network

\begin{tabular}{|c|c|c|c|c|c|}
\hline \multirow[b]{2}{*}{ Station number } & \multicolumn{5}{|c|}{$\begin{array}{c}\text { Standard error of instantaneous discharge, in percent } \\
\text { [Equivalent Gaussian spread] } \\
\text { (Number of visits per year to site) }\end{array}$} \\
\hline & $\begin{array}{l}\text { Current } \\
\text { operation } \\
423 \\
\end{array}$ & $\begin{array}{l}\text { Current budget, } \\
\text { using optimum } \\
\text { routes } \\
423\end{array}$ & 400 & 500 & 600 \\
\hline 02489500 & $\begin{array}{l}18.0 \\
{[5.9]} \\
(8)\end{array}$ & $\begin{array}{l}18.0 \\
{[5.9]} \\
(8)\end{array}$ & $\begin{array}{l}18.0 \\
{[5.9]} \\
(8)\end{array}$ & $\begin{array}{l}13.8 \\
{[5.0]} \\
(14)\end{array}$ & $\begin{array}{l}10.8 \\
{[4.2]} \\
(23)\end{array}$ \\
\hline 02490105 & $\begin{array}{l}21.4 \\
{[4.4]} \\
(8)\end{array}$ & $\begin{array}{l}21.4 \\
{[4.4]} \\
(8)\end{array}$ & $\begin{array}{l}21.4 \\
{[4.4]} \\
(8)\end{array}$ & $\begin{array}{l}16.4 \\
{[3.5]} \\
(14)\end{array}$ & $\begin{array}{l}12.9 \\
{[2.8]} \\
(23)\end{array}$ \\
\hline 02492000 & $\begin{array}{l}20.8 \\
{[4.6]} \\
(8)\end{array}$ & $\begin{array}{l}20.8 \\
{[4.6]} \\
(8)\end{array}$ & $\begin{array}{l}20.8 \\
{[4.6]} \\
(8)\end{array}$ & $\begin{array}{l}15.9 \\
{[3.4]} \\
(14)\end{array}$ & $\begin{array}{l}12.5 \\
{[2.6]} \\
(23)\end{array}$ \\
\hline 07344400 & $\begin{array}{l}31.6 \\
{[9.5]} \\
(4)\end{array}$ & $\begin{array}{l}20.0 \\
{[6.3]} \\
(11)^{3}\end{array}$ & $\begin{array}{l}31.6 \\
{[9.5]} \\
(4)\end{array}$ & $\begin{array}{l}14.7 \\
{[4.7]} \\
(21)\end{array}$ & $\begin{array}{l}10.7 \\
{[3.5]} \\
(40)\end{array}$ \\
\hline 07344450 & $\begin{array}{l}54.8 \\
{[8.9]} \\
(8)\end{array}$ & $\begin{array}{l}45.1 \\
{[7.1]} \\
(12)\end{array}$ & $\begin{array}{l}62.7 \\
{[10.6]} \\
(6)\end{array}$ & $\begin{array}{l}31.0 \\
{[4.7]} \\
(26)\end{array}$ & $\begin{array}{l}23.6 \\
{[3.7]} \\
(45)\end{array}$ \\
\hline 07348000 & $\begin{array}{c}40.0 \\
{[24.6]} \\
(8)\end{array}$ & $\begin{array}{l}34.6 \\
{[22.5]} \\
(12)\end{array}$ & $\begin{array}{l}44.4 \\
{[26.0]} \\
(6)\end{array}$ & $\begin{array}{l}25.5 \\
{[17.8]} \\
(26)\end{array}$ & $\begin{array}{l}20.0 \\
{[14.2]} \\
(45)\end{array}$ \\
\hline 07348700 & $\begin{array}{l}33.7 \\
{[7.3]} \\
(8)\end{array}$ & $\begin{array}{l}31.8 \\
{[6.9]} \\
(9)\end{array}$ & $\begin{array}{l}41.8 \\
{[9.0]} \\
(5)\end{array}$ & $\begin{array}{l}19.5 \\
{[4.3]} \\
(25)\end{array}$ & $\begin{array}{l}14.9 \\
{[3.3]} \\
(43)\end{array}$ \\
\hline 07349374 & $\begin{array}{l}0.0 \\
{[0.0]} \\
(8)\end{array}$ & $\begin{array}{l}0.0 \\
{[0.0]} \\
(12)\end{array}$ & $\begin{array}{l}0.0 \\
{[0.0]} \\
(6)\end{array}$ & $\begin{array}{c}0.0 \\
{[0.0]} \\
(26)\end{array}$ & $\begin{array}{l}0.0 \\
{[0.0]} \\
(45)\end{array}$ \\
\hline 07349500 & $\begin{array}{l}32.2 \\
{[5.1]} \\
(8)\end{array}$ & $\begin{array}{l}30.5 \\
{[4.9]} \\
(9)\end{array}$ & $\begin{array}{l}40.1 \\
{[6.4]} \\
(5)\end{array}$ & $\begin{array}{l}18.6 \\
{[3.0]} \\
(25)\end{array}$ & $\begin{array}{l}14.2 \\
{[2.4]} \\
(43)\end{array}$ \\
\hline 07349795 & $\begin{array}{l}35.3 \\
{[17.2]} \\
(8)\end{array}$ & $\begin{array}{l}29.2 \\
{[14.0]} \\
(12)\end{array}$ & $\begin{array}{c}40.1 \\
{[19.7]} \\
(6)\end{array}$ & $\begin{array}{l}20.1 \\
{[9.4]} \\
(26)\end{array}$ & $\begin{array}{l}15.4 \\
{[7.1]} \\
(45)\end{array}$ \\
\hline
\end{tabular}


Table 14.--Selected results of Kalman-Filtering for Cost-Effective Resource Allocation analysis of Louisiana stream-gaging network--Continued

\begin{tabular}{|c|c|c|c|c|c|}
\hline \multirow[b]{3}{*}{ Station number } & \multicolumn{5}{|c|}{$\begin{array}{c}\text { Standard error of instantaneous discharge, in percent } \\
\text { [Equivalent Gaussian spread] } \\
\text { (Number of visits per year to site) }\end{array}$} \\
\hline & $\begin{array}{l}\text { Current } \\
\text { operation }\end{array}$ & $\begin{array}{c}\text { Current budget, } \\
\text { using optimum } \\
\text { routes }\end{array}$ & & & \\
\hline & 423 & 423 & 400 & 500 & 600 \\
\hline 07349860 & $\begin{array}{l}28.4 \\
{[8.2]} \\
(8)\end{array}$ & $\begin{array}{l}23.5 \\
{[7.0]} \\
(12)\end{array}$ & $\begin{array}{l}32.4 \\
{[9.1]} \\
(6)\end{array}$ & $\begin{array}{l}16.3 \\
{[5.2]} \\
(26)\end{array}$ & $\begin{array}{l}12.5 \\
{[4.0]} \\
(45)\end{array}$ \\
\hline 07350020 & $\begin{array}{l}0.0 \\
{[0.0]} \\
(9)\end{array}$ & $\begin{array}{l}0.0 \\
{[0.0]} \\
(8)\end{array}$ & $\begin{array}{l}0.0 \\
{[0.0]} \\
(6)\end{array}$ & $\begin{array}{c}0.0 \\
{[0.0]} \\
(26)\end{array}$ & $\begin{array}{l}0.0 \\
{[0.0]} \\
(6)\end{array}$ \\
\hline 07351500 & $\begin{array}{c}40.3 \\
{[25.8]} \\
(8)\end{array}$ & $\begin{array}{l}33.2 \\
{[20.8]} \\
(12)\end{array}$ & $\begin{array}{c}45.9 \\
{[29.8]} \\
(6)\end{array}$ & $\begin{array}{l}22.8 \\
{[13.8]} \\
(26)\end{array}$ & $\begin{array}{l}17.3 \\
{[10.3]} \\
(45)^{3}\end{array}$ \\
\hline 07351600 & $\begin{array}{l}25.3 \\
{[14.4]} \\
(9)\end{array}$ & $\begin{array}{c}26.5 \\
{[15.0]} \\
(8)\end{array}$ & $\begin{array}{l}29.8 \\
{[16.4]} \\
(6)\end{array}$ & $\begin{array}{l}21.6 \\
{[12.6]} \\
(13)\end{array}$ & $\begin{array}{l}16.7 \\
{[9.8]} \\
(23)\end{array}$ \\
\hline 07351748 & $\begin{array}{l}0.0 \\
{[0.0]} \\
(9)\end{array}$ & $\begin{array}{l}0.0 \\
{[0.0]} \\
(6)\end{array}$ & $\begin{array}{l}0.0 \\
{[0.0]} \\
(4)\end{array}$ & $\begin{array}{l}0.0 \\
{[0.0]} \\
(4)\end{array}$ & $\begin{array}{l}0.0 \\
{[0.0]} \\
(4)\end{array}$ \\
\hline 07351750 & $\begin{array}{l}37.8 \\
{[9.8]} \\
(9)\end{array}$ & $\begin{array}{l}37.8 \\
{[9.8]} \\
(9)\end{array}$ & $\begin{array}{c}46.7 \\
{[12.9]} \\
(6)\end{array}$ & $\begin{array}{l}24.8 \\
{[6.0]} \\
(20)\end{array}$ & $\begin{array}{l}19.2 \\
{[4.6]} \\
(33)\end{array}$ \\
\hline 07352000 & $\begin{array}{l}32.7 \\
{[24.1]} \\
(12)\end{array}$ & $\begin{array}{l}32.7 \\
{[24.1]} \\
(12)\end{array}$ & $\begin{array}{l}32.7 \\
{[24.1]} \\
(12)\end{array}$ & $\begin{array}{l}22.3 \\
{[17.0]} \\
(31)\end{array}$ & $\begin{array}{l}17.2 \\
{[13.2]} \\
(54)\end{array}$ \\
\hline 07352800 & $\begin{array}{c}56.2 \\
{[43.1]} \\
(9)\end{array}$ & $\begin{array}{l}54.3 \\
{[42.0]} \\
(10)\end{array}$ & $\begin{array}{c}63.7 \\
{[47.2]} \\
(6)\end{array}$ & $\begin{array}{l}33.9 \\
{[27.2]} \\
(34)\end{array}$ & $\begin{array}{l}25.9 \\
{[20.7]} \\
(60)\end{array}$ \\
\hline 07354100 & $\begin{array}{l}43.2 \\
{[11.0]} \\
(9)\end{array}$ & $\begin{array}{l}41.1 \\
{[10.9]} \\
(10)^{2}\end{array}$ & $\begin{array}{l}52.8 \\
{[11.7]} \\
(6)\end{array}$ & $\begin{array}{l}26.7 \\
{[9.7]} \\
(25)\end{array}$ & $\begin{array}{l}20.6 \\
{[8.7]} \\
(44)\end{array}$ \\
\hline 07364100 & $\begin{array}{l}20.3 \\
{[8.0]} \\
(8)\end{array}$ & $\begin{array}{l}23.6 \\
{[9.1]} \\
(6)\end{array}$ & $\begin{array}{l}23.6 \\
{[9.1]} \\
(6)\end{array}$ & $\begin{array}{l}15.9 \\
{[6.4]} \\
(13)^{1}\end{array}$ & $\begin{array}{l}12.4 \\
{[5.0]} \\
(21)\end{array}$ \\
\hline
\end{tabular}


Table 14.--Selected results of Kalman-Filtering for Cost-Effective Resource Allocation analys is of Louisiana stream-gaging network--Continued

\begin{tabular}{|c|c|c|c|c|c|}
\hline \multirow[b]{2}{*}{ Station number } & \multicolumn{5}{|c|}{$\begin{array}{c}\text { Standard error of instantaneous discharge, in percent } \\
\text { [Equivalent Gaussian spread] } \\
\text { (Number of visits per year to site) }\end{array}$} \\
\hline & $\begin{array}{l}\text { Current } \\
\text { operation } \\
423 \\
\end{array}$ & $\begin{array}{l}\text { Current budget, } \\
\text { using opt imum } \\
\text { routes } \\
423\end{array}$ & 400 & 500 & 600 \\
\hline 07364200 & $\begin{array}{l}29.8 \\
{[3.6]} \\
(8)\end{array}$ & $\begin{array}{l}27.0 \\
{[3.1]} \\
(10)\end{array}$ & $\begin{array}{l}33.7 \\
{[4.6]} \\
(6)\end{array}$ & $\begin{array}{l}20.0 \\
{[2.1]} \\
(19)\end{array}$ & $\begin{array}{l}15.4 \\
{[1.5]} \\
(33)\end{array}$ \\
\hline 07364890 & $\begin{array}{l}0.0 \\
0.0] \\
(8)\end{array}$ & $\begin{array}{l}0.0 \\
{[0.0]} \\
(4)\end{array}$ & $\begin{array}{l}0.0 \\
{[0.0]} \\
(4)\end{array}$ & $\begin{array}{l}0.0 \\
{[0.0]} \\
(4)\end{array}$ & $\begin{array}{l}0.0 \\
{[0.0]} \\
(4)\end{array}$ \\
\hline 07366200 & $\begin{array}{l}40.2 \\
{[11.7]} \\
(8)\end{array}$ & $\begin{array}{c}32.8 \\
9.5] \\
(12)\end{array}$ & $\begin{array}{l}43.0 \\
{[12.5]} \\
(7)\end{array}$ & $\begin{array}{l}20.1 \\
{[5.8]} \\
(32)\end{array}$ & $\begin{array}{l}15.7 \\
{[4.6]} \\
(52)\end{array}$ \\
\hline 07367630 & $\begin{array}{c}0.0 \\
{[0.0]} \\
(26)\end{array}$ & $\begin{array}{c}0.0 \\
{[0.0]} \\
(26)\end{array}$ & $\begin{array}{c}0.0 \\
{[0.0]} \\
(26)\end{array}$ & $\begin{array}{c}0.0 \\
{[0.0]} \\
(26)\end{array}$ & $\begin{array}{c}0.0 \\
{[0.0]} \\
(26)\end{array}$ \\
\hline 07368000 & $\begin{array}{c}46.3 \\
{[35.6]} \\
(8)\end{array}$ & $\begin{array}{l}39.8 \\
{[29.9]} \\
(12)\end{array}$ & $\begin{array}{c}51.0 \\
{[39.8]} \\
(6)\end{array}$ & $\begin{array}{l}24.4 \\
{[17.1]} \\
(36)\end{array}$ & $\begin{array}{l}18.6 \\
{[12.8]} \\
(63)\end{array}$ \\
\hline 07369000 & $\begin{array}{c}0.0 \\
{[0.0]} \\
(12)\end{array}$ & $\begin{array}{l}0.0 \\
{[0.0]} \\
(10)^{0}\end{array}$ & $\begin{array}{l}0.0 \\
{[0.0]} \\
(6)\end{array}$ & $\begin{array}{c}0.0 \\
{[0.0]} \\
(19)\end{array}$ & $\begin{array}{c}0.0 \\
{[0.0]} \\
(33)\end{array}$ \\
\hline 07369500 & $\begin{array}{c}52.8 \\
{[12.3]} \\
(8)\end{array}$ & $\begin{array}{l}47.8 \\
{[10.5]} \\
(10)\end{array}$ & $\begin{array}{l}59.8 \\
{[15.4]} \\
(6)\end{array}$ & $\begin{array}{l}35.6 \\
{[7.0]} \\
(19)\end{array}$ & $\begin{array}{l}27.3 \\
{[5.2]} \\
(33)\end{array}$ \\
\hline 07369700 & $\begin{array}{l}16.1 \\
{[1.7]} \\
(8)\end{array}$ & $\begin{array}{l}14.5 \\
{[1.5]} \\
(10)\end{array}$ & $\begin{array}{l}18.4 \\
{[1.9]} \\
(6)\end{array}$ & $\begin{array}{l}10.6 \\
{[1.1]} \\
(19)\end{array}$ & $\begin{array}{c}8.1 \\
{[0.8]} \\
(33)\end{array}$ \\
\hline 07370000 & $\begin{array}{c}45.2 \\
{[32.6]} \\
(8)\end{array}$ & $\begin{array}{l}38.4 \\
{[26.8]} \\
(12)\end{array}$ & $\begin{array}{l}50.1 \\
{[37.2]} \\
(6)^{2}\end{array}$ & $\begin{array}{l}23.2 \\
{[14.8]} \\
(36)\end{array}$ & $\begin{array}{l}17.6 \\
{[11.0]} \\
(63)\end{array}$ \\
\hline 07371500 & $\begin{array}{l}33.9 \\
{[8.4]} \\
(8)\end{array}$ & $\begin{array}{l}28.1 \\
{[7.2]} \\
(12)\end{array}$ & $\begin{array}{l}42.0 \\
{[9.9]} \\
(5)\end{array}$ & $\begin{array}{l}17.8 \\
{[4.8]} \\
(31)\end{array}$ & $\begin{array}{l}13.5 \\
{[3.7]} \\
(54)\end{array}$ \\
\hline
\end{tabular}


Table 14.--Selected results of Kalman-Filtering for Cost-Effective Resource Allocation analysis of Louisiana stream-gaging network--Continued

\begin{tabular}{|c|c|c|c|c|c|}
\hline \multirow[b]{2}{*}{ Station number } & \multicolumn{5}{|c|}{$\begin{array}{c}\text { Standard error of instantaneous discharge, in percent } \\
\text { [Equivalent Gaussian spread] } \\
\text { (Number of visits per year to site) }\end{array}$} \\
\hline & $\begin{array}{l}\text { Current } \\
\text { operation } \\
423\end{array}$ & $\begin{array}{l}\text { Current budget, } \\
\text { using optimum } \\
\text { routes } \\
423\end{array}$ & 400 & 500 & 600 \\
\hline 07372200 & $\begin{array}{l}62.3 \\
{[14.5]} \\
(9)\end{array}$ & $\begin{array}{l}48.4 \\
{\left[\begin{array}{l}12.8] \\
(16)\end{array}\right.}\end{array}$ & $\begin{array}{l}62.3 \\
{\left[\begin{array}{l}14.5 \\
(9)\end{array}\right.}\end{array}$ & $\begin{array}{l}30 \cdot 5 \\
{[10 \cdot 9]} \\
(45)\end{array}$ & $\begin{array}{l}24.1 \\
{[9.7]} \\
(76)\end{array}$ \\
\hline 07373000 & $\begin{array}{l}28.9 \\
{[4.0]} \\
(12)\end{array}$ & $\begin{array}{l}27.7 \\
{[3.8]} \\
(14)\end{array}$ & $\begin{array}{l}29.8 \\
{[4.0]} \\
(12)\end{array}$ & $\begin{array}{l}16.4 \\
{[2.5]} \\
(41)\end{array}$ & $\begin{array}{l}13.0 \\
{[2.1]} \\
(66)\end{array}$ \\
\hline 07373250 & $\begin{array}{l}34.4 \\
{[6.1]} \\
(9)\end{array}$ & $\begin{array}{l}36.4 \\
{[6.5]} \\
(8)\end{array}$ & $\begin{array}{l}41.6 \\
{[7.4]} \\
(6)\end{array}$ & $\begin{array}{l}21.9 \\
{[3.9]} \\
(23)\end{array}$ & $\begin{array}{l}17.1 \\
{[3.1]} \\
(38)\end{array}$ \\
\hline 07375000 & $\begin{array}{l}22.3 \\
{[5.6]} \\
(8)\end{array}$ & $\begin{array}{l}22.3 \\
{[5.6]} \\
(8)\end{array}$ & $\begin{array}{l}22.3 \\
{[5.6]} \\
(8)\end{array}$ & $\begin{array}{l}17.2 \\
{[4.6]} \\
(14)\end{array}$ & $\begin{array}{l}13.5 \\
{[3.7]} \\
(23)\end{array}$ \\
\hline 07375500 & $\begin{array}{l}18.6 \\
{[7.1]} \\
(8)\end{array}$ & $\begin{array}{l}19.7 \\
{[7.5]} \\
(7)\end{array}$ & $\begin{array}{l}25.2 \\
{[9.6]} \\
(4)\end{array}$ & $\begin{array}{l}12.4 \\
{[4.7]} \\
(19)\end{array}$ & $\begin{array}{l}9.6 \\
{[3.7]} \\
(32)\end{array}$ \\
\hline 07376000 & $\begin{array}{l}19.7 \\
{[7.6]} \\
(8)\end{array}$ & $\begin{array}{l}22.6 \\
{[8.8]} \\
(6)\end{array}$ & $\begin{array}{l}27.1 \\
{[10.8]} \\
(4)\end{array}$ & $\begin{array}{l}15.1 \\
{[5.8]} \\
(14)\end{array}$ & $\begin{array}{l}11.2 \\
{[4.2]} \\
(26)\end{array}$ \\
\hline 07376500 & $\begin{array}{l}43.5 \\
{[15.2]} \\
(8)\end{array}$ & $\begin{array}{l}46.4 \\
{[16.5]} \\
(7)\end{array}$ & $\begin{array}{l}60.0 \\
{\left[\begin{array}{l}23.4 \\
(4)\end{array}\right.}\end{array}$ & $\begin{array}{l}28.7 \\
{[9.3]} \\
(19)\end{array}$ & $\begin{array}{l}22.2 \\
{[7.1]} \\
(32)\end{array}$ \\
\hline 07377000 & $\begin{array}{l}23.2 \\
{[5.6]} \\
(8)\end{array}$ & $\begin{array}{l}24.7 \\
{[6.0]} \\
(7)\end{array}$ & $\begin{array}{l}32.1 \\
{[8.4]} \\
(4)\end{array}$ & $\begin{array}{l}16.6 \\
{[3.8]} \\
(16)\end{array}$ & $\begin{array}{l}12.9 \\
{[3.0]} \\
(27)\end{array}$ \\
\hline 07377240 & $\begin{array}{l}45.9 \\
{[31.8]} \\
(8)\end{array}$ & $\begin{array}{l}41.2 \\
{[29.6]} \\
(11)\end{array}$ & $\begin{array}{c}57.7 \\
{[36.7]} \\
(4)\end{array}$ & $\begin{array}{l}31.3 \\
{[23.6]} \\
(23)\end{array}$ & $\begin{array}{l}24.1 \\
{[18.4]} \\
(42)\end{array}$ \\
\hline 07377500 & $\begin{array}{l}29.5 \\
{[9.4]} \\
(8)\end{array}$ & $\begin{array}{l}26.5 \\
{[8.4]} \\
(10)\end{array}$ & $\begin{array}{l}36.7 \\
{[11.9]} \\
(5)\end{array}$ & $\begin{array}{l}16.7 \\
{[5.2]} \\
(26)\end{array}$ & $\begin{array}{l}13.0 \\
{[4.0]} \\
(44)\end{array}$ \\
\hline
\end{tabular}


Table 14.--Selected results of Kalman-Filtering for Cost-Effective Resource Allocation analysis of Louisiana stream-gaging network--Continued

\begin{tabular}{|c|c|c|c|c|c|}
\hline \multirow[b]{2}{*}{ Station number } & \multicolumn{5}{|c|}{$\begin{array}{c}\text { Standard error of instantaneous discharge, in percent } \\
\text { [Equivalent Gaussian spread] } \\
\text { (Number of visits per year to site) }\end{array}$} \\
\hline & $\begin{array}{l}\text { Current } \\
\text { operation } \\
423 \\
\end{array}$ & $\begin{array}{l}\text { Current budget, } \\
\text { using opt imum } \\
\text { routes } \\
423\end{array}$ & 400 & 500 & 600 \\
\hline 07377755 & $\begin{array}{l}0.0 \\
{[0.0]} \\
(8)\end{array}$ & $\begin{array}{l}0.0 \\
{[0.0]} \\
(4)\end{array}$ & $\begin{array}{l}0.0 \\
{[0.0]} \\
(4)\end{array}$ & $\begin{array}{l}0.0 \\
{[0.0]} \\
(4)\end{array}$ & $\begin{array}{l}0.0 \\
{[0.0]} \\
(4)\end{array}$ \\
\hline 07377782 & $\begin{array}{c}39.9 \\
{[12.3]} \\
(8)\end{array}$ & $\begin{array}{l}36.0 \\
{[11.3]} \\
(10)\end{array}$ & $\begin{array}{c}45.4 \\
{[13.7]} \\
(6)\end{array}$ & $\begin{array}{l}20.9 \\
{[6.8]} \\
(31)^{2}\end{array}$ & $\begin{array}{l}16.2 \\
{[5.3]} \\
(52)\end{array}$ \\
\hline 07377842 & $\begin{array}{l}0.0 \\
{[0.0]} \\
(8)\end{array}$ & $\begin{array}{l}0.0 \\
{[0.0]} \\
(4)\end{array}$ & $\begin{array}{l}0.0 \\
{[0.0]} \\
(4)\end{array}$ & $\begin{array}{l}0.0 \\
{[0.0]} \\
(4)\end{array}$ & $\begin{array}{l}0.0 \\
{[0.0]} \\
(4)\end{array}$ \\
\hline 07378000 & $\begin{array}{l}35.0 \\
{[17.4]} \\
(8)^{4}\end{array}$ & $\begin{array}{l}27.8 \\
{[13.2]} \\
(13)\end{array}$ & $\begin{array}{c}35.0 \\
{[17.4]} \\
(8)^{4}\end{array}$ & $\begin{array}{l}17.2 \\
{[7.8]} \\
(35)\end{array}$ & $\begin{array}{l}13.1 \\
{[5.9]} \\
(61)\end{array}$ \\
\hline 07378500 & $\begin{array}{l}16.7 \\
{[9.9]} \\
(8)\end{array}$ & $\begin{array}{c}19.1 \\
{[11.6]} \\
(6)\end{array}$ & $\begin{array}{c}19.1 \\
{[11.6]} \\
(6)\end{array}$ & $\begin{array}{l}17.9 \\
{[7.5]} \\
(14)\end{array}$ & $\begin{array}{l}10.4 \\
{[5.9]} \\
(22)^{2}\end{array}$ \\
\hline 07380400 & $\begin{array}{l}0.0 \\
{[0.0]} \\
(8)\end{array}$ & $\begin{array}{l}0.0 \\
{[0.0]} \\
(4)\end{array}$ & $\begin{array}{l}0.0 \\
{[0.0]} \\
(4)^{0}\end{array}$ & $\begin{array}{l}0.0 \\
{[0.0]} \\
(4)\end{array}$ & $\begin{array}{l}0.0 \\
{[0.0]} \\
(4)\end{array}$ \\
\hline 07381800 & $\begin{array}{l}26.3 \\
{[0.9]} \\
(9)\end{array}$ & $\begin{array}{l}27.8 \\
{[1.0]} \\
(8)\end{array}$ & $\begin{array}{l}34.6 \\
{[1.2]} \\
(5)\end{array}$ & $\begin{array}{l}17.0 \\
{[0.6]} \\
(22)\end{array}$ & $\begin{array}{l}13.0 \\
{[0.5]} \\
(38)\end{array}$ \\
\hline 07382000 & $\begin{array}{l}11.6 \\
{[2.8]} \\
(9)\end{array}$ & $\begin{array}{l}74.1 \\
{[3.5]} \\
(6)\end{array}$ & $\begin{array}{l}14.1 \\
{[3.5]} \\
(6)\end{array}$ & $\begin{array}{l}8.8 \\
{[2.2]} \\
(16)\end{array}$ & $\begin{array}{c}6.7 \\
{[1.6]} \\
(28)\end{array}$ \\
\hline 07382500 & $\begin{array}{c}27.5 \\
{[13.4]} \\
(9)\end{array}$ & $\begin{array}{c}28.8 \\
{[13.8]} \\
(8)\end{array}$ & $\begin{array}{l}32.0 \\
{[15.0]} \\
(6)\end{array}$ & $\begin{array}{l}19.4 \\
{[11.4]} \\
(23)\end{array}$ & $\begin{array}{l}15.4 \\
{[10.3]} \\
(45)\end{array}$ \\
\hline 07383500 & $\begin{array}{l}30.6 \\
{[13.2]} \\
(9)^{2}\end{array}$ & $\begin{array}{l}36.3 \\
{[17.4]} \\
(6)^{4}\end{array}$ & $\begin{array}{c}36.3 \\
{[17.4]} \\
(6)^{3}\end{array}$ & $\begin{array}{l}23.5 \\
{[9.2]} \\
(16)\end{array}$ & $\begin{array}{l}18.1 \\
{[6.7]} \\
(28)\end{array}$ \\
\hline
\end{tabular}


Table 14.--Selected results of Kalman-Filtering for Cost-Effective Resource Allocation analysis of Louisiana stream-gaging network--Continued

\begin{tabular}{|c|c|c|c|c|c|}
\hline \multirow[b]{2}{*}{ Station number } & \multicolumn{5}{|c|}{$\begin{array}{c}\begin{array}{c}\text { Standard error of instantaneous discharge, in percent } \\
\text { [Equivalent Gaussian spread] } \\
\text { (Number of visits per year to site) }\end{array} \\
1984 \text { budget, in thousands of dollars }\end{array}$} \\
\hline & $\begin{array}{l}\text { Current } \\
\text { operation } \\
423 \\
\end{array}$ & $\begin{array}{l}\text { Current budget, } \\
\text { using optimum } \\
\text { routes } \\
423\end{array}$ & 400 & 500 & 600 \\
\hline 07385500 & $\begin{array}{l}13.0 \\
{[3.8]} \\
(9)\end{array}$ & $\begin{array}{l}15.4 \\
{[4.8]} \\
(6)\end{array}$ & $\begin{array}{l}15.4 \\
{[4.8]} \\
(6)\end{array}$ & $\begin{array}{l}10.0 \\
{[2.8]} \\
(16)\end{array}$ & $\begin{array}{l}7.7 \\
{[2.1]}\end{array}$ \\
\hline 07385700 & $\begin{array}{l}14.1 \\
{[9.1]} \\
(9)\end{array}$ & $\begin{array}{l}16.5 \\
{[9.8]} \\
(6)\end{array}$ & $\begin{array}{l}16.5 \\
{[9.8]} \\
(6)\end{array}$ & $\begin{array}{l}16.5 \\
{[9.8]} \\
(6)\end{array}$ & $\begin{array}{l}13.6 \\
{[9.0]} \\
(10)\end{array}$ \\
\hline 07386200 & $\begin{array}{l}0.0 \\
{[0.0]} \\
(9)\end{array}$ & $\begin{array}{l}0.0 \\
{[0.0]} \\
(6)\end{array}$ & $\begin{array}{l}0.0 \\
{[0.0]} \\
(6)\end{array}$ & $\begin{array}{l}0.0 \\
{[0.0]} \\
(16)\end{array}$ & $\begin{array}{c}0.0 \\
{[0.0]} \\
(28)\end{array}$ \\
\hline 07386700 & $\begin{array}{l}23.9 \\
{[2.4]} \\
(9)\end{array}$ & $\begin{array}{l}29.0 \\
{[3.0]} \\
(6)\end{array}$ & $\begin{array}{l}29.0 \\
{[3.0]} \\
(6)\end{array}$ & $\begin{array}{l}18.0 \\
{[1.9]} \\
(16)\end{array}$ & $\begin{array}{l}13.7 \\
{[1.4]} \\
(28)\end{array}$ \\
\hline 07386880 & $\begin{array}{l}0.0 \\
{[0.0]} \\
(9)\end{array}$ & $\begin{array}{l}0.0 \\
{[0.0]} \\
(6)\end{array}$ & $\begin{array}{l}0.0 \\
{[0.0]} \\
(6)\end{array}$ & $\begin{array}{l}0.0 \\
{[0.0]} \\
(6)\end{array}$ & $\begin{array}{c}0.0 \\
{[0.0]} \\
(10)\end{array}$ \\
\hline 08010000 & $\begin{array}{c}64.2 \\
{[18.9]} \\
(9)\end{array}$ & $\begin{array}{l}45.7 \\
{[12.2]} \\
(19)\end{array}$ & $\begin{array}{c}64.2 \\
{[18.9]} \\
(9)\end{array}$ & $\begin{array}{l}29.2 \\
{[7.3]} \\
(48)\end{array}$ & $\begin{array}{l}22.8 \\
{[5.6]} \\
(80)\end{array}$ \\
\hline 08012000 & $\begin{array}{c}54.7 \\
{[35.8]} \\
(9)\end{array}$ & $\begin{array}{l}40.9 \\
{[26.8]} \\
(19)\end{array}$ & $\begin{array}{c}57.1 \\
{[37.3]} \\
(8)\end{array}$ & $\begin{array}{l}26.8 \\
{[17.1]} \\
(48)\end{array}$ & $\begin{array}{l}20.9 \\
{[13.1]} \\
(80)\end{array}$ \\
\hline 08013000 & $\begin{array}{l}25.0 \\
{[4.5]} \\
(9)\end{array}$ & $\begin{array}{l}26.5 \\
{[4.7]} \\
(8)\end{array}$ & $\begin{array}{l}33.0 \\
{[5.5]} \\
(5)\end{array}$ & $\begin{array}{l}16.3 \\
{[3.2]} \\
(22)\end{array}$ & $\begin{array}{l}12.4 \\
{[2.5]} \\
(38)\end{array}$ \\
\hline 08013500 & $\begin{array}{l}19.8 \\
{[5.2]} \\
(12)\end{array}$ & $\begin{array}{l}19.8 \\
{[5.2]} \\
(12)\end{array}$ & $\begin{array}{l}19.8 \\
{[5.2]} \\
(12)\end{array}$ & $\begin{array}{l}17.8 \\
{[4.7]} \\
(15)\end{array}$ & $\begin{array}{l}13.4 \\
{[3.6]} \\
(27)\end{array}$ \\
\hline 08014500 & $\begin{array}{l}17.4 \\
{[4.1]} \\
(9)\end{array}$ & $\begin{array}{l}17.4 \\
{[4.1]} \\
(4)\end{array}$ & $\begin{array}{l}25.3 \\
{[6.1]} \\
(4)\end{array}$ & $\begin{array}{l}13.6 \\
{[3.2]} \\
(15)^{2}\end{array}$ & $\begin{array}{l}10.2 \\
{[2.4]} \\
(27)\end{array}$ \\
\hline
\end{tabular}


Table 14.--Selected results of Kalman-Filtering for Cost-Effective Resource Allocation analysis of Louisiana stream-gaging network--Continued

\begin{tabular}{|c|c|c|c|c|c|}
\hline \multirow{2}{*}{ Station number } & \multicolumn{5}{|c|}{$\begin{array}{c}\text { Standard error of instantaneous discharge, in percent } \\
\text { [Equivalent Gaussian spread] } \\
\text { (Number of visits per year to site) }\end{array}$} \\
\hline & $\begin{array}{l}\text { Current } \\
\text { operation }\end{array}$ & $\begin{array}{l}\text { Current budget, } \\
\text { using optimum } \\
\text { routes }\end{array}$ & חم & 500 & $6 \cap 0$ \\
\hline 08015500 & $\begin{array}{l}13.2 \\
{[8.6]} \\
(12)\end{array}$ & $\begin{array}{l}20.8 \\
{[13.5]} \\
(4)\end{array}$ & $\begin{array}{l}20.8 \\
{[13.5]}\end{array}$ & $\begin{array}{l}14.3 \\
{[9.3]} \\
(10)\end{array}$ & $\begin{array}{l}11.2 \\
{[7.3]} \\
(17)\end{array}$ \\
\hline 08016400 & $\begin{array}{c}41.8 \\
{[18.2]} \\
(9)\end{array}$ & $\begin{array}{l}35.3 \\
{[15.4]} \\
(13)\end{array}$ & $\begin{array}{c}44.1 \\
{[19.1]} \\
(8)\end{array}$ & $\begin{array}{l}21.6 \\
{[9.3]} \\
(36)\end{array}$ & $\begin{array}{l}17.1 \\
{[7.3]} \\
(58)\end{array}$ \\
\hline 08016800 & $\begin{array}{l}39.7 \\
{[12.8]} \\
(9)\end{array}$ & $\begin{array}{l}36.2 \\
{[11.9]} \\
(11)\end{array}$ & $\begin{array}{c}41.8 \\
{[13.4]} \\
(8)\end{array}$ & $\begin{array}{l}20.5 \\
{[7.1]} \\
(36)\end{array}$ & $\begin{array}{l}19.3 \\
{[6.7]} \\
(41)\end{array}$ \\
\hline 08022765 & $\begin{array}{c}41.2 \\
{[20.2]} \\
(9)\end{array}$ & $\begin{array}{c}41.2 \\
{[20.2]} \\
(9)\end{array}$ & $\begin{array}{c}59.1 \\
{[30.5]} \\
(4)\end{array}$ & $\begin{array}{l}28.8 \\
{[13.5]} \\
(19)\end{array}$ & $\begin{array}{l}22.0 \\
{[10.1]} \\
(33)\end{array}$ \\
\hline 08023080 & $\begin{array}{l}0.0 \\
{[0.0]} \\
(9)\end{array}$ & $\begin{array}{l}0.0 \\
{[0.0]} \\
(6)\end{array}$ & $\begin{array}{l}0.0 \\
{[0.0]} \\
(4)\end{array}$ & $\begin{array}{l}0.0 \\
{[0.0]} \\
(4)\end{array}$ & $\begin{array}{l}0.0 \\
{[0.0]} \\
(4)\end{array}$ \\
\hline 08023400 & $\begin{array}{l}34.9 \\
{[21.3]} \\
(9)\end{array}$ & $\begin{array}{l}38.6 \\
{[23.2]} \\
(7)\end{array}$ & $\begin{array}{c}47.8 \\
{[27.6]} \\
(4)\end{array}$ & $\begin{array}{l}25.8 \\
{[16.0]} \\
(18)\end{array}$ & $\begin{array}{l}20.0 \\
{[13.4]} \\
(31)\end{array}$ \\
\hline 08025500 & $\begin{array}{l}36.4 \\
{[9.3]} \\
(12)\end{array}$ & $\begin{array}{l}36.4 \\
{[9.3]} \\
(12)\end{array}$ & $\begin{array}{l}36.4 \\
{[9.3]} \\
(12)\end{array}$ & $\begin{array}{l}24.6 \\
{[6.5]} \\
(27)\end{array}$ & $\begin{array}{l}18.9 \\
{[5.1]} \\
(46)\end{array}$ \\
\hline 08028000 & $\begin{array}{l}35.2 \\
{[7.3]} \\
(9)\end{array}$ & $\begin{array}{l}32.0 \\
{[6.5]} \\
(11)^{2}\end{array}$ & $\begin{array}{l}51.2 \\
{[11.6]} \\
(4)\end{array}$ & $\begin{array}{l}20.7 \\
{[4.1]} \\
(27)\end{array}$ & $\begin{array}{l}15.9 \\
{[3.2]} \\
(46)^{2}\end{array}$ \\
\hline $\begin{array}{l}\text { Total average } \\
\text { error }\end{array}$ & $\begin{array}{c}34.6 \\
{[10.3]}\end{array}$ & $\begin{array}{l}31.5 \\
{[9.8]}\end{array}$ & $\begin{array}{c}39.6 \\
{[12.3]}\end{array}$ & $\begin{array}{l}21.0 \\
{[6.6]}\end{array}$ & $\begin{array}{l}16.3 \\
{[5.1]}\end{array}$ \\
\hline
\end{tabular}


$\$ 423,000$ to operate the 68 gages along with a number of non-continuous stream gages and wells on the stream-gaging routes and results in an average standard error of estimate of 34.6 percent. The results also indicate that, by using the routes and number of measurements prescribed by the "Traveling Hydrographer Program," the same 34.6 percent standard error can be achieved for about $\$ 410,000$, or the error can be reduced to 31.5 percent for the current budget. The maximum budget analyzed was $\$ 600,000$, and it produces a 16.3 percent standard error of estimation.

The study indicates that a major source of error is due to lost or missing data. If perfect equipment were available, the standard error for the current program and budget could be reduced to 11.8 percent. This can al so be interpreted to mean that the streamflow data has a standard error of this magnitude during times when equipment is operating properly.

The analysis also was performed to estimate the uncertainty in stream-gaging records assumming that no stream-gage data were lost because of less than perfect instrumentation. The dashed curve, labeled "complete" in figure 11, shows the average standard errors of estimation of streamflow that could be obtained if perfectly reliable systems were available to measure and record the data. For the minimal operational budget of $\$ 400,000$, the impacts of less than perfect equipment are greatest, and the average standard error could be reduced from 39.6 to 14.2 percent with no missing record.

At the other budgetary extreme of $\$ 600,000$, under which stations are visited more frequently and the reliability of equipment should be less sensitive, average standard errors are 16.3 percent for the current systems of sensing and recording of hydrologic data and 6.5 percent for the ideal equipment. Thus, improved equipment can have a very positive impact on streamflow uncertainties throughout the range of operational budgets for the stream-gaging program in Louisiana.

\section{Conclusions from the Kalman-Filtering for cost Effective Resource Allocation Analysis}

As a result of the K-CERA analysis, the following suggestions are offered:

1. The number of visits to several stream gages should be altered to decrease the average standard error of estimate of streamflow. This shift would result in some increases and decreases in accuracy of records at individual sites. The sites that require changes are listed in table 15.

2. After the above suggestions are implemented, stations for which errors of estimation are large should be discussed with the funding agency or to determine if these large errors are acceptable for the intended use of the data. If these errors are not acceptable, then additional funds are needed to reduce the amount of missing record. Reducing missing record with telemark systems could reduce the error of estimate of streamflow at a number of sites. 
Table 15.--Stations suggested for altered visitation schedules as a result of the Kalman-Filtering for Cost-Effective Resource Allocation analysis

\begin{tabular}{llc}
\hline $\begin{array}{l}\text { Station } \\
\text { number }\end{array}$ & $\begin{array}{c}\text { Current number of } \\
\text { measurements per year }\end{array}$ & $\begin{array}{c}\text { Suggested number of } \\
\text { measurements per year }\end{array}$ \\
\hline 07344400 & 4 & 12 \\
07344450 & 8 & 12 \\
07348000 & 8 & 12 \\
07349374 & 8 & 12 \\
07349795 & 8 & 12 \\
07349860 & 8 & 12 \\
07351500 & 8 & 12 \\
07372200 & 9 & 12 \\
07377240 & 8 & 12 \\
07378000 & 8 & 12 \\
07381800 & 9 & 8 \\
07382000 & 9 & 6 \\
07383500 & 9 & 6 \\
07385500 & 9 & 6 \\
07385700 & 9 & 6 \\
07386200 & 9 & 6 \\
07386700 & 9 & 6 \\
07386880 & 9 & 12 \\
08010000 & 9 & 12 \\
08012000 & 9 & 4 \\
08013000 & 9 & 12 \\
08015500 & 9 & 12 \\
08016400 & 9 & \\
08016800 & 9 & \\
& 9 & \\
\hline
\end{tabular}

3. A number of stations were not included in this analysis and several stations included had insufficient data to apply the Kalman-filtering technique. When enough data become available, these stations should be incorporated into this analysis and the results evaluated.

\section{SUMMARY}

Currently (1984), 68 continuous-record stream gages are operating in Louisiana at a cost of $\$ 408,700$. Seven separate sources of funding contribute to this program and data are used for eight different purposes. Although the stream-gaging program is large, little information has been collected in the coastal marsh region and in urban areas. In 1983 and 1984, the Survey began collecting data at several new sites in both of these areas. However, the stations in those programs were not included in this analysis. 
In an analysis of the uses that are made of the data, five stations were identified that are supported for a short-term study. It is suggested that two of these stations be discontinued at the end of the study. One of the stations, Bayou Pierre (07351750), should be continued to document long-term changes in streamflow and in sediment yield.

The current operation of the 68-station program could be slightly improved by making some minor changes in the frequency of discharge measurements at several sites. These changes should be implemented.

A major component of the error in streamflow records is caused by loss of primary record (stage or other correlative data) at the stream gages because of malfunctions of sensing and recording equipment. Upgrading equipment and developing strategies to minimize lost record appear to be key actions required to improve the reliability and accuracy of the streamflow data generated in the State.

Studies of the cost effectiveness of the stream-gaging program should be continued and should include investigation of the optimum number of discharge measurements for each station, as well as investigation of cost-effective ways of reducing the probabilities of lost correlative data. Future studies also will be required because of changes in demands for streamflow information with addition and deletion for stream gages. Such changes will impact the operation of other stations in the program, both because of the dependence between stations of the information that is generated (data redundancy) and because of the dependence of the costs of collecting the data from which the information is derived.

\section{SELECTED REFERENCES}

Benson, M. A. and Carter, R. W., 1973, A national study of the streamflow data-collection program: U.S. Geological Survey Water-Supply Paper 2028, 44 p.

Carter, R. F., 1970, Evaluation of the surface-water data program in Georgia: U.S. Geological Survey Open-File Report, 65 p.

Doyle, W. H. Jr., Shearman, J. 0., Stiltner, G. J., and Krug, W., 1983, A digital model for streamflow routing by convolution methods: U.S. Geological Survey Water-Resources Investigations 83-4160, 130 p.

Draper, N. R. and Smith, H., 1966, Applied regression analysis: New York, N.Y., John Wiley and Sons, 2d ed., 709 p.

Fontaine, R. A., Moss, M. E., Smath, J. A., and Thomas, W. 0., Jr., 1983, Cost-effectiveness of the stream-gaging program in Maine; a prototype for nationwide implementation: U.S. Geological Survey Water-Supply Paper 2244, 39 p.

Ge1b, A., ed., 1974, Applied optimal estimation: The Massachusetts Institute of Technology Press, Cambridge, Mass., 374 p. 
Gilroy, E. J. and Moss, M. E., 1981, Cost-effective stream gaging strategies for the lower Colorado River basin: U.S. Geological Survey Open-File Report 81-1019, $38 \mathrm{p}$.

Hale, T.W., Stokes, W. R., Price, M., Pearman, J.L., Carter, R. F., and Ryan, S. E., 1984, Cost effectiveness of the stream-gaging program in Georgia, U.S. Geological Survey Water-Resources Investigations Report $84-4190,144 \mathrm{p}$.

Hutchinson, N. E. 1975, WATSTORE--National Water Data Storage and Retrieval System of the U.S. Geological Survey--User's guide, volume 1: U.S. Geological Survey Open-File Report 75-426, 791 p.

Keefer, T. N. 1974, Desktop computer flow routing: American Society of Civil Engineers Proceedings, Journal of the Hydraulics Division, $v$. 100, no. HY7, p. 1047-1058.

Keefer, T. N. and McQuivey, R. S., 1974, Multiple linearization flow routing model: American Society of Civil Engineers Proceedings, Journal of the Hydraulics Division, v. 100, no. HY7, p. 1031-1046.

Kleinbaum, D. G. and Kupper, L. L., 1978, Applied regression analysis and other multivariable methods: North Scituate, Mass., Duxbury Press, $556 \mathrm{p}$.

Mitche11, W. D., 1962, Effect of reservoir storage on peak flow: U.S. Geological Survey Water-Supply Paper 1580-C, p. C1-C25.

Moss, M. E. and Gilroy, E. J., 1980, Cost effective stream-gaging strategies for the Lower Colorado River basin: U.S. Geological Survey Open-File Report 80-1048, $128 \mathrm{p}$.

Moss, M. E., Gilroy, E. J., Tasker, G. D., and Karlinger, M. R., 1982, Design of surface-water data networks for regional information: U.S. Geological Survey Water-Supply Paper 2178, 33 p.

Riggs, H. C., 1973, Regional analyses of streamflow characteristics: U.S. Geological Survey Techniques of Water-Resources Investigations, book 4, chap. B3, $15 \mathrm{p}$.

Sauer, V. B., 1964, Floods in Louisiana, magnitude and frequency, 2d ed.: Louisiana Department of Highways, 402 p.

1973, Unit response method of open-channel flow routing: American Society of Civil Engineers Proceedings: Journal of the Hydraulics Division, v. 99, no. HYl, p. 179-193.

Thomas, D. M. and Benson, M. A., 1970, Generalization of streamf low characteristics from drainage-basin characteristics: U.S. Geological Survey Water-Supply Paper 1975, $55 \mathrm{p}$.

U.S. Geological Survey, 1982, Water Resources Data for Louisiana, water year 1982: U.S. Geological Survey Water Data Report LA-82-1, 2. 